\title{
FERRUGEM E MANCHA ANGULAR DO FEIJOEIRO: EFEITO DE FUNGICIDAS NO DESENVOLVIMENTO DO HOSPEDEIRO E NO PROGRESSO DAS DOENÇAS
}

NILCELI FERNANDES - BUZZERIO

Dissertação apresentada à Escola Superior de Agricultura "Luiz de Queiroz", Universidade de São Paulo, para obtenção do título de Mestre em Agronomia, Área de Concentração: Fitopatologia.

P I R A C I C A B A

Estado de São Paulo - Brasil

Novembro - 2001 


\title{
FERRUGEM E MANCHA ANGULAR DO FEIJOEIRO: EFEITO DE FUNGICIDAS NO DESENVOLVIMENTO DO HOSPEDEIRO E NO PROGRESSO DAS DOENÇAS
}

\author{
NILCELI FERNANDES - BUZZERIO
}

Bióloga

Orientador: Prof. Dr. ARMANDO BERGAMIN FILHO

Dissertação apresentada à Escola Superior de Agricultura "Luiz de Queiroz", Universidade de São Paulo, para obtenção do título de Mestre em Agronomia, Área de Concentração: Fitopatologia.

P I R A C I C A B A

Estado de São Paulo - Brasil

Novembro - 2001 
Dados Internacionais de Catalogação na Publicação (CIP) DIVISÃO DE BIBLIOTECA E DOCUMENTAÇÃO - ESALQ/USP

\section{Fernandes-Buzzerio, Nilceli}

Ferrugem e mancha angular do feijoeiro : efeito de fungicidas no

desenvolvimento do hospedeiro e no progresso das doenças / Nilceli Fernandes-

Buzzerio. - - Piracicaba, 2001.

$115 \mathrm{p}$.

Dissertação (mestrado) - - Escola Superior de Agricultura Luiz de Queiroz, 2001.

Bibliografia.

1. Feijão 2. Ferrugem (doença de planta) 3. Fungicidas 4. Mancha angular I. Título

CDD 635.652

"Permitida a cópia total ou parcial deste documento, desde que citada a fonte - O autor" 
À minha querida mãe Doralice

Ao meu pai Antonio e irmãos Nanci, Nelson e Neiva,

e a toda a minha família, que mesmo sem

compreender a minha vida científica me apoiaram

em todos os momentos

\title{
DEDICO
}

\author{
“Ninguém comete erro maior do que não fazer nada \\ por que só pode fazer pouco." \\ (Edmund Burke - Filósofo Irlandês (1729-1797)
}

Ao meu amado esposo André pela paciência, amor, respeito e pela compreensão das minhas ausências, 


\section{AGRADECIMENTOS}

Agradeço a DEUS, todo poderoso, por me acompanhar em todos os momentos de minha vida e por ter colocado em meu caminho, minha querida amiga e "irmã torta" Silvia Afonseca Lourenço, sem a qual esta Dissertação jamais seria concluída.

À Escola Superior de Agricultura "Luiz de Queiroz", em especial ao Departamento de Entomologia, Fitopatologia e Zoologia Agrícola por ter me dado a oportunidade de conhecer este maravilhoso mundo da Fitopatologia.

À Escola Profa. Catharina Casale Padovani e a Universidade Metodista de Piracicaba, professores e amigos pelo aprendizado e formação de caráter.

À empresária Walquíria Moda de Souza pelo estímulo a minha entrada na Universidade.

Ao Prof. Dr. Armando Bergamin Filho pela orientação e estímulo a capacidade de raciocínio.

À Profa. Dra. Lilian Amorim, por todos os momentos de dedicação e amizade a mim dispensados desde os primeiros dias de estágio no Departamento em 1995.

Ao querido amigo Dr. Leonardo Gianasi pela co-orientação nesta Dissertação e sugestões preciosas em toda a minha vida científica.

Ao Prof. Dr. Hiroshi Kimati e a Dra. Marise C. M. Parisi, não só pelo ensino científico, mas também humano.

Às amigas Elisa, Cássia e Marissônia por todo carinho e auxílio a mim dispensado.

Á CAPES e FAPESP pelo financiamento parcial deste trabalho.

À todos os professores do Departamento pelas valiosas contribuições. 
Ao Sr. Pedro Arthuso que mesmo diante de tantas dificuldades sempre esteve ao meu lado incentivando e me ensinando como manejar meus experimentos.

Aos funcionários Jeferson, Marina, Fernanda, Rodolpho, Edivaldo e a minha querida Maria Heloisa e aos vários amigos, Cecília G. Diaz, Claudia Tofanelli, Bringel, Ivone Schoenmaker, João Parisi, Renata, Daniela Truffi, Larissa May de Mio, Leliane, Raquel (Charqueada), Célia Malvas, Célia Tremacoldi, Ana Paula, Robinson, Fabiana, Hélio, Renato, enfim TODOS os amigos do Departamento de Fitopatologia que passaram por mim deixando boas lembranças e que sempre estiveram prontos a me ajudar em todos os momentos, desde auxiliando nas laboriosas avaliações dos experimentos até confortando-me nos momentos tristes. Saudades...

À bibliotecária Eliana M. Garcia pela paciência nas correção dos formatos e das referências bibliográficas e a bibliotecária Maria Cristina M. R. de Andrade pela confecção da ficha catalográfica.

À Hokko do Brasil Ind. Quím e Agropecuária Ltda. pelo fornecimento do fungicida oxycarboxin utilizado nos ensaios de ferrugem e a todos os amigos da Estação Experimental de Pereiras.

Ao querido amigo Walter Pereira pelo total apoio durante a condução dos me us experimentos e também aos amigos José Ferreira, Claudionir, Meneghel.

Aos maravilhosos amigos e colegas de trabalho Domingos Pedroni, Sérgio B. Paiva, Carlos Fabri, Antonio Nascimento, Débora, Jairo, Lisanne, Leandro, Maria de Lourdes, Claudette, Sônia, Isabel, André Bachiega, Santiago, Carlos, Karl, Carlos Gustavo, Luis Gustavo, Leandro Sitta, Dagoberto, Luis Straito, Luiz Guedes e a todos da Syngenta Proteção de Cultivos Ltda., pelo incentivo a este trabalho e pela contribuição à minha vida profissiona $1 \mathrm{e}$ pessoal.

À amiga Claudia Godoy e aos amigos José Soto Veiga e Thomas Altmann pela correção da Dissertação e elaboração do Summary.

À toda a família Sitta (Mario Luis, Catherine, William e Jonathan) pelo convívio familiar.

À quem por ventura eu possa ter esquecido de citar, mas que de alguma forma desempenhou papel essencial na conclusão de mais essa etapa de minha vida.

À você que por algum motivo consultou este trabalho, espero ter ajudado. 


\section{SUMÁRIO}

LISTA DE FIGURAS................................................................................. ix

LISTA DE TABELAS...........................................................................

LISTA DE SIGLAS, ABREVIATURAS E SÍMBOLOS....................................... x xii

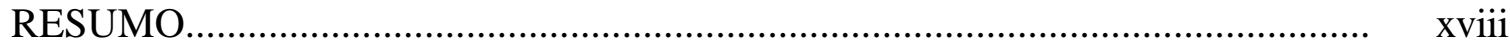

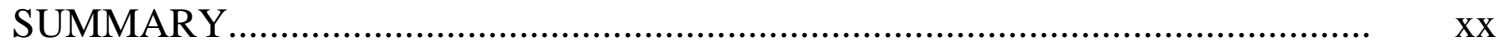

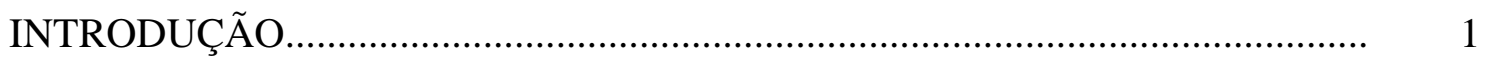

2 REVISÃO DE LITERATURA.................................................................. 5

2.1 Ferrugem do Feijoeiro [Uromyces appendiculatus (Pers.:Pers.) Unger]............. 5

2.1.1 Etiologia e Morfologia................................................................................. 5

2.1.2 Sintomatologia .......................................................................................

2.1.3 Ocorrência e Importância............................................................................... 6

2.1.4 Epidemiologia e Controle da Doença.............................................................. 7

2.2 Mancha Angular do Feijoeiro (Phaeoisariopsis griseola (Sacc.) Ferraris......... 9

2.2.1 Etiologia e morfologia...............................................................................

2.2.2 Sintomatologia ................................................................................... 10

2.2.3 Ocorrência e Importância............................................................................... 10

2.2.4 Epidemiologia e Controle da Doença................................................................ 11

2.3 Quantificação de Danos..................................................................................... 14

2.3.1 Modelos para a Estimativa de Danos............................................................ 15

2.4 Avaliação de Danos através da Área Foliar Fotossintetizante.............................. 16

2.5 Manejo Integrado de Doenças........................................................................... 20

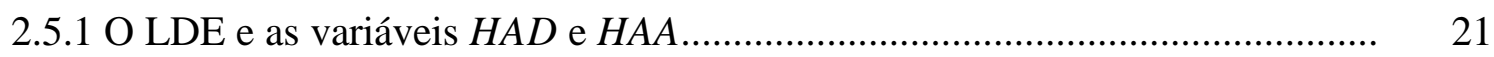

2.6 Sensoriamento Remoto................................................................................. 24

3 MATERIAL E MÉTODOS........................................................................ 28 
3.1 Instalação dos Ensaios em Campo.................................................................... 28

3.2 Avaliações do Desenvolvimento do Hospedeiro, Severidade da Doença e

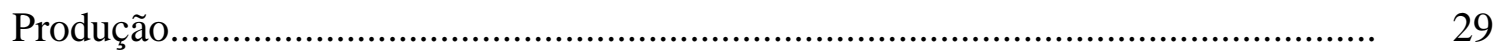

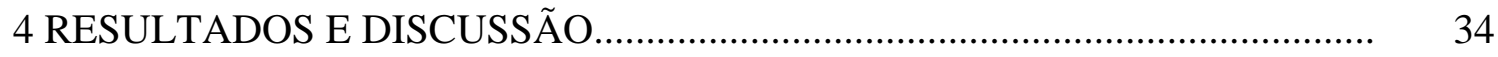

4.1 Forma de análise dos resultados................................................................ 34

4.1.1 Cálculo da área sob a curva de progresso da doença $(A U D P C)$.................... 34

4.1.2 Porcentagem de Desfolha........................................................................... 35

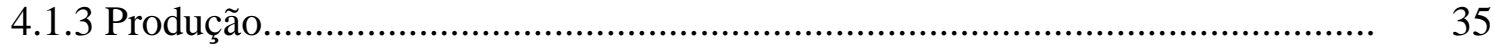

4.1.4 Dados obtidos com o Ceptômetro................................................................ 37

4.2 Dados Climáticos e Radiação Solar................................................................. 37

4.3 Área Foliar, Área sob a Curva de Progresso da Doença (AUDPC), Duração da Área Foliar Sadia $(H A D)$, Absorção da Área Foliar Sadia $(H A A)$ e Produção......... 41

4.4 Área foliar Sadia (HLAI), Radiação Interceptada pela Área Foliar Sadia (HRI)

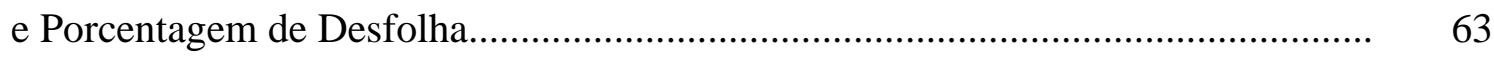

4.5 Limiar de Dano Econômico: A Tomada de Decisão........................................ 75

4.6 Comparação dos dados do Índice de Área entre Foliar ( $L A I)$ obtidos de avaliações diretas (LAI Manual) e indiretas com o Ceptômetro (LAI Ceptômetro) • 86

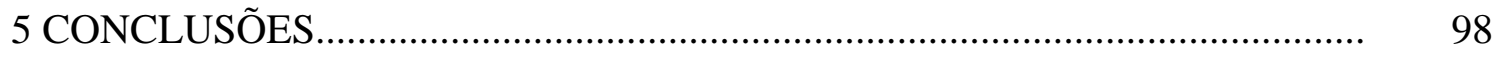

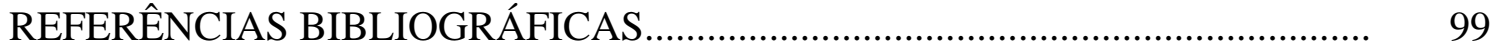




\section{LISTA DE FIGURAS}

Página

1 Escala diagramática da severidade (porcentagem de área foliar afetada) da ferrugem do feijoeiro, causada por Uromyces appendiculatus (Godoy, et al., 1997). Piracicaba, São Paulo, 1998 - 2000

2 Escala diagramática da severidade (porcentagem de área foliar afetada) da mancha angular do feijoeiro, causada por Phaeoisariopsis griseola (Godoy, et al., 1997). Piracicaba, São Paulo, 1998 - 2000.

3 Valores médios da área foliar $(\mathrm{cm})$ dos experimentos C1 e C3 (ferrugem oxycarboxin) e dos experimentos C2 e C4 (mancha angular - trifenil hidróxido de estanho) do feijoeiro. Piracicaba, São Paulo, 1998 - 2000.

4 Valores individuais da área sob a curva de progresso da doença (AUDPC) (60 plantas) promovida pela ferrugem (experimentos C1 e C3) e pela mancha angular (experimentos C2 e C4) do feijoeiro. Piracicaba, São Paulo, 1998 2000 .

5 Área sob a curva de progresso da doença $(A U D P C)$ promovida pela ferrugem (experimentos C1 e C3) e mancha angular (experimentos C2 e C4) do feijoeiro. Valores médios de 12 plantas por tratamento. Piracicaba, São Paulo, 1998 - 2000.

6 Área sob a curva de progresso da doença $(A U D P C)$ promovida pela ferrugem (experimentos C1 e C3) e mancha angular (experimentos C2 e C4) do feijoeiro. Valores médios de 12 plantas por tratamento. Médias Seguidas de mesma letra não diferem significativamente entre si pelo teste de Tukey (p<0,05). Piracicaba, São Paulo, 1998 - 2000. 
7 Produção gramas por planta dos experimentos C1, C3 (ferrugem oxycarboxin), C2 e C4 (mancha angular - trifenil hidróxido de estanho) do feijoeiro. Médias \pm desvio padrão de 12 plantas por tratamento. Médias seguidas de mesma letra não diferem significativamente entre si pelo teste de Tukey (p<0,05). Piracicaba, São Paulo, 1998 - 2000...................................

8 Produção gramas por parcela dos experimentos C1, C3 (ferrugem oxycarboxin), C2 e C4 (mancha angular - trifenil hidróxido de estanho) do feijoeiro. Médias \pm desvio padrão de três parcelas por tratamento. Médias seguidas de mesma letra não diferem significativamente entre si pelo teste de Tukey (p<0,05). Piracicaba, São Paulo, 1998 - 2000....................................

9 Relação entre $A U D P C$ e produção (gramas por planta) de 60 plantas dos experimentos C1, C3 (ferrugem - oxycarboxin), C2 e C4 (mancha angular trifenil hidróxido de estanho) do feijoeiro. Piracicaba, São Paulo, 1998 2000.

10 Médias \pm desvio padrão de 12 plantas por tratamento de $H A D$ (dias) dos experimentos C1, C3 (ferrugem - oxycarboxin), C2 e C4 (mancha angular trifenil hidróxido de estanho) do feijoeiro. Médias seguidas de mesma letra não diferem significativamente entre si pelo teste de Tukey $(\mathrm{p}<0,05)$. Piracicaba, São Paulo, 1998 - 2000.

11 Médias \pm desvio padrão de 12 plantas por tratamento de $H A A\left(\mathrm{MJ} \mathrm{m}^{-2}\right)$ dos experimentos C1, C3 (ferrugem - oxycarboxin), C2 e C4 (mancha angular trifenil hidróxido de estanho) do feijoeiro. Médias seguidas de mesma letra não diferem significativamente entre si pelo teste de Tukey $(\mathrm{p}<0,05)$. Piracicaba, São Paulo, 1998 - 2000.

12 Relação entre $H A D$ (dias) e produção (gramas por planta) dos experimentos C1, C3 (ferrugem - oxycarboxin), C2 e C4 (mancha angular - trifenil hidróxido de estanho) do feijoeiro. Piracicaba, São Paulo, 1998 - 2000...........

13 Relação entre HAA ( $\mathrm{MJ} \mathrm{m}^{-2}$ ) e produção (gramas por planta) dos experimentos $\mathrm{C} 1$, C3 (ferrugem - oxycarboxin), C2 e C4 (mancha angular - trifenil hidróxido de estanho) do feijoeiro. Piracicaba, São Paulo, 1998 - 2000 
14 Análise conjunta dos dados entre $H A D$ (dias) e produção (gramas/planta) dos experimentos $\mathrm{C} 1, \mathrm{C} 3$ (ferrugem - oxycarboxin), $\mathrm{C} 2$ e $\mathrm{C} 4$ (mancha angular trifenil hidróxido de estanho). Piracicaba, São Paulo, 1998 - 2000.................. 62

15 Análise conjunta dos dados entre $H A A\left(\mathrm{MJ} \mathrm{m}^{-2}\right)$ e produção (gramas/planta) dos experimentos C1, C3 (ferrugem - oxycarboxin), C2 e C4 (mancha angular - trifenil hidróxido de estanho). Piracicaba, São Paulo, 1998 - 2000...

16 Efeito da ferrugem - oxycarboxin (experimentos C1 e C3) e mancha angular - trifenil hidróxido de estanho (experimentos C2 e C4) do feijoeiro sobre o índice de área foliar sadio (HLAI). Piracicaba, São Paulo, 1998 - 2000............

17 Porcentagem média de desfolha $( \pm$ desvio padrão de 12 plantas por tratamento) obtida dos experimentos $\mathrm{C} 1, \mathrm{C} 3$ (ferrugem - oxycarboxin), C2 e C4 (mancha angular - trifenil hidróxido de estanho) do feijoeiro. Médias seguidas de mesma letra não diferem significativamente entre si pelo teste de Tukey (p<0,05). Piracicaba, São Paulo, 1998 - 2000

18 Produção (gramas por planta) versus porcentagem de desfolha, para plantas individuais de feijão infectadas com ferrugem (C1 e C3) e mancha angular (C2 e C4) (60 plantas por experimento). Piracicaba, São Paulo, 1998 - 2000.

19 Número de folhas emitidas obtidas dos experimentos C1, C3 (ferrugem oxycarboxin), C2 e C4 (mancha angular - trifenil hidróxido de estanho) do feijoeiro. Médias \pm desvio padrão de 12 plantas por tratamento. Médias Seguidas de mesma letra não diferem significativamente entre si pelo teste de Tukey (p<0,05). Piracicaba, São Paulo, 1998 - 2000.

20 Curvas de progresso do número de folhas emitidas em função dos experimentos C1, C3 (ferrugem - oxycarboxin), C2 e C4 (mancha angular trifenil hidróxido de estanho) do feijoeiro. Médias \pm desvio padrão de 12 plantas por tratamento. Médias seguidas de mesma letra não diferem significativamente entre si pelo teste de Tukey $(\mathrm{p}<0,05)$. Piracicaba, São Paulo, 1998 - 2000..

21 Porcentagens de desfolha em função do tempo obtidas dos experimentos $\mathrm{C} 1$, C3 (ferrugem - oxycarboxin), C2 e C4 (mancha angular - trifenil hidróxido 
de estanho) do feijoeiro. Médias \pm desvio padrão de 12 plantas por tratamento. Médias seguidas de mesma letra não diferem significativamente entre si pelo teste de Tukey ( $\mathrm{p}<0,05)$. Piracicaba, São Paulo, 1998 - 2000.......

22 Relação entre HLAI (dias) e produção (gramas por planta) dos experimentos C1, C3 (ferrugem - oxycarboxin), C2 e C4 (mancha angular - trifenil hidróxido de estanho do feijoeiro. Piracicaba, São Paulo, 1998 - 2000............

23 Análise conjunta dos dados entre HLAI e produção (gramas/planta) dos experimentos C1, C3 (ferrugem - oxycarboxin), C2 e C4 (mancha angular trifenil hidróxido de estanho). Piracicaba, São Paulo, 1998 - 2000...................

24 Efeito da ferrugem - oxycarboxin (experimentos C1 e C3) e mancha angular - trifenil hidróxido de estanho (experimentos C2 e C4) do feijoeiro sobre a radiação interceptada pela área foliar sadia por unidade de tempo (HRI, MJ $\mathrm{m}^{-2}$ ). Médias de 12 plantas por tratamento. Piracicaba, São Paulo, 1998-2000. 73

25 Relação entre HRI (MJ m ${ }^{-2}$ e produção (gramas por planta) dos experimentos C1, C3 (ferrugem - oxycarboxin), C2 e C4 (mancha angular trifenil hidróxido de estanho) do feijoeiro. Piracicaba, São Paulo, 1998 2000 .

26 Análise conjunta dos dados entre $H R I\left(\mathrm{MJ} \mathrm{m}^{-2}\right)$ e produção (gramas/planta) dos experimentos C1, C3 (ferrugem - oxycarboxin), C2 e C4 (mancha angular - trifenil hidróxido de estanho). Piracicaba, São Paulo, 1998 - 2000...

27 Coeficientes angulares obtidos pela regressão linear, com passagem forçada pela origem da produção (gramas por planta) com índice de área foliar sadio (HLAI) medidos nos estádios de crescimento do feijoeiro infectado com a ferrugem $(\mathrm{C} 1, \mathrm{C} 3)$ e mancha angular $(\mathrm{C} 2, \mathrm{C} 4)$. Estádios de crescimento: $\mathrm{V}_{3}=$ primeira folha trifoliolada; $\mathrm{V}_{4}=$ terceira folha trifoliolada; $\mathrm{R}_{5}=$ pré florescimento; $\mathrm{R}_{6}=$ florescimento; $\mathrm{R}_{7}=$ formação das vagens; $\mathrm{R}_{8}=$ enchimento das vagens e $R_{9}=$ maturidade fisiológica (Michaelis, 1994). Piracicaba, São Paulo, 1998 - 2000.

28 Coeficientes angulares obtidos pela regressão linear, com passagem forçada pela origem da produção (gramas por planta) com radiação interceptada pela 
área foliar sadia por unidade de tempo $\left(H R I, \mathrm{MJ} \mathrm{m}^{-2}\right)$ medido nos estádios de crescimento do feijoeiro infectado com a ferrugem (C1 e C3) e mancha angular (C2 e C4). Estádios de crescimento: $V_{3}=$ primeira folha trifoliolada; $\mathrm{V}_{4}=$ terceira folha trifoliolada; $\mathrm{R}_{5}=$ pré - florescimento; $\mathrm{R}_{6}=$ florescimento; $\mathrm{R}_{7}=$ formação das vagens $; \mathrm{R}_{8}=$ enchimento das vagens e $\mathrm{R}_{9}=$ maturidade fisiológica (Michaelis, 1994). Piracicaba, São Paulo, 1998 2000 .

29 Índice de Área Foliar Sadio (HLAI) do feijoeiro infectado com a ferrugem (C1 e C3) e mancha angular (C2 e C4) para os tratamentos T1 (s/ pulverização com fungicidas e com duas inoculações artificiais em intervalo de 10 dias) e T5 (aplicações semanais de fungicida e sem inoculação). Piracicaba, São Paulo, 1998 - 2000.

30 Radiação Interceptada pela área foliar sadia por unidade de tempo $(H R I)$ do feijoeiro infectado com a ferrugem (C1 e C3) e mancha angular (C2 e C4) para os tratamentos $\mathrm{T} 1$ (s/ pulverização com fungicidas e com duas inoculações artificiais em intervalo de 10 dias) e T5 (aplicações semanais de fungicida e sem inoculação). Piracicaba, São Paulo, 1998 - 2000.....................

31 Estimativas comparativas dos Índices de Área Foliar obtido através de medições diretas da área foliar (LAI Manual) e indiretamente com ceptômetro (LAI Ceptômetro) do experimento C1 (ferrugem - oxycarboxin). Piracicaba, São Paulo, 1998 - 2000

32 Estimativas comparativas dos Índices de Área Foliar obtido através de medições diretas da área foliar (LAI Manual) e indiretamente com ceptômetro (LAI Ceptômetro) do experimento C2 (mancha angular - trifenil hidróxido de estanho). Piracicaba, São Paulo, 1998 - 2000.

33 Estimativas comparativas dos Índices de Área Foliar obtido através de medições diretas da área foliar (LAI Manual) e indiretamente com ceptômetro (LAI Ceptômetro) do experimento C3 (ferrugem - oxycarboxin). Piracicaba, São Paulo, 1998 - 2000 
34 Estimativas comparativas dos Índices de Área Foliar obtido através de medições diretas da área foliar (LAI Manual) e indiretamente com ceptômetro (LAI Ceptômetro) do experimento C4 (ferrugem - oxycarboxin).

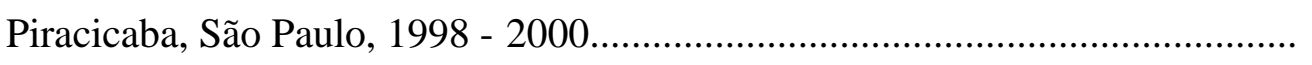

35 Relação entre as estimativas comparativas dos Índices de Área Foliar obtido através de medições diretas da área foliar (LAI Manual) e indiretamente com ceptômetro (LAI Ceptômetro) do experimento C1 (ferrugem - oxycarboxin). Piracicaba, São Paulo, 1998 - 2000.

36 Relação entre as estimativas comparativas dos Índices de Área Foliar obtido através de medições diretas da área foliar (LAI Manual) e indiretamente com ceptômetro (LAI Ceptômetro) do experimento C2 (mancha angular - trifenil hidróxido de estanho). Piracicaba, São Paulo, 1998 - 2000.

37 Relação entre as estimativas comparativas dos Índices de Área Foliar obtido através de medições diretas da área foliar (LAI Manual) e indiretamente com ceptômetro (LAI Ceptômetro) do experimento C3 (ferrugem - oxycarboxin). Piracicaba, São Paulo, 1998 - 2000..

38 Relação entre as estimativas comparativas dos Índices de Área Foliar obtido através de medições diretas da área foliar (LAI Manual) e indiretamente com ceptômetro (LAI Ceptômetro) do experimento C4 (mancha angular - trifenil hidróxido de estanho). Piracicaba, São Paulo, 1998 - 2000

39 Análise conjunta dos dados entre as estimativas obtidas através de medições diretas da área foliar (LAI Manual) e indiretamente com ceptômetro (LAI Ceptômetro) dos quatro experimentos. Piracicaba, São Paulo, 1998 - 2000..... 


\section{LISTA DE TABELAS}

Página

1 Características dos defensivos agrícolas utilizados nos experimentos com a ferrugem $(\mathrm{C} 1, \mathrm{C} 3)$ e com a mancha angular $(\mathrm{C} 2, \mathrm{C} 4)$ do feijoeiro. Piracicaba,

São Paulo, 1998 - 2000...................................................................... 32

2 Descrição dos tratamentos realizados nos experimentos com a ferrugem $(\mathrm{C} 1$, C3) e com a mancha angular (C2, C4) do feijoeiro. Piracicaba, São Paulo,

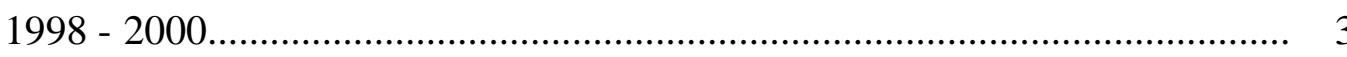

3 Dados climáticos realizados durante a execução do experimento C1 (ferrugem - oxycarboxin). Piracicaba, São Paulo, 1998 - 2000........................

4 Dados climáticos realizados durante a execução do experimento do C2 (mancha angular - trifenil hidróxido de estanho). Piracicaba, São Paulo, 1998 $-2000$.

5 Dados climáticos realizados durante a execução do experimento do C3 (ferrugem - oxycarboxin). Piracicaba, São Paulo, 1998 - 2000.

6 Dados climáticos realizados durante a execução do experimento do $\mathrm{C} 4$. (mancha angular - trifenil hidróxido de estanho). Piracicaba, São Paulo, 1998 $-2000$.

7 Época de pulverização dos experimentos C1, C3 (ferrugem), C2 e C4 (mancha angular) com os fungicidas oxycarboxin e trifenil hidróxido de estanho, respectivamente. Piracicaba. São Paulo, 1998 - 2000

8 Dados dos componentes da produção número de vagens viáveis, no. De sementes viáveis e peso sementes (gramas) obtidos do experimento $\mathrm{C} 1, \mathrm{C} 2$, C3 e C4. Piracicaba, São Paulo. 1998 - 2000 
9 Coeficientes angulares ( \pm erro padrão) das retas de regressão (passagem forçada através da origem) entre produção (gramas/planta) e índice de área foliar sadio (HLAI) e entre produção (gramas/planta) e radiação interceptada pela área foliar sadia $\left(H R I, \mathrm{MJ} \mathrm{m}^{-2}\right)$, em diferentes estádios de crescimento do feijoeiro (GS), quantificados no patossistema ferrugem (C1 e C3) e mancha angular (C2 e C4). Piracicaba, São Paulo, 1998 - 2000

10 Dados dos Índices de Área Foliar obtido de avaliações diretas da área foliar (LAI Manual) e indiretamente com o ceptômetro (LAI Ceptômetro) do experimento Cl (ferrugem - oxycarboxin). Piracicaba, São Paulo, 1998 2000 .

11 Dados dos Índices de Área Foliar obtido de avaliações diretas da área foliar (LAI Manual) e indiretamente com o ceptômetro (LAI Ceptômetro) do experimento C2 (mancha angular - trifenil hidróxido de estanho). Piracicaba,

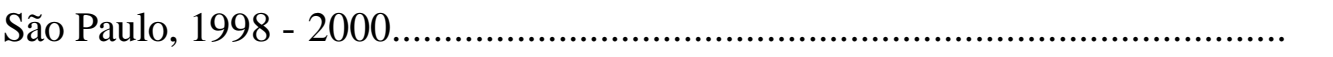

12 Dados dos Índices de Área Foliar obtido de avaliações diretas da área foliar (LAI Manual) e indiretamente com o ceptômetro (LAI Ceptômetro) do experimento C3 (ferrugem - oxycarboxin). Piracicaba, São Paulo, 1998 2000.

13 Dados dos Índices de Área Foliar obtido de avaliações diretas da área foliar (LAI Manual) e indiretamente com o ceptômetro (LAI Ceptômetro) do experimento C4 (mancha angular - trifenil hidróxido de estanho). Piracicaba, São Paulo, 1998 - 2000 


\section{LISTA DE SIGLAS, ABREVIATURAS E SÍMBOLOS}

AUDPC: $\quad$ Área sob a curva de progresso da doença (Area Under Disease Progress Curve).

C1: $\quad$ Experimento 1: ferrugem - oxycarboxin.

C2: $\quad$ Experimento 2: `mancha angular - trifenil hidróxido de estanho.

C3: $\quad$ Experimento 3: ferrugem - oxycarboxin.

C4: $\quad$ Experimento 4: `mancha angular - trifenil hidróxido de estanho.

DAP: $\quad$ Dias após o plantio.

HAA: $\quad$ Absorção da área foliar sadia (Healthy Area Absorption).

HAD: $\quad$ Duração da área foliar sadia (Healthy Leaf Area Duration).

HLAI: $\quad$ Índice de área foliar sadio (Healthy Leaf Area Index).

HRI: Absorção da área foliar sadia por unidade de tempo Healthy Radiation Intercepted).

LAA: $\quad$ Absorção da área foliar (Leaf Area Absorption).

LAD: $\quad$ Duração da área foliar (Leaf Area Duration).

LAI: $\quad$ Índice de área foliar (Leaf Area Index).

LBE: Limiar biológico de dano.

LDE: Limiar de dano econômico.

$\mathrm{V}_{3}$ : $\quad$ Primeira folha trifoliolada (Michaelis, 1994).

$\mathrm{V}_{4}$ : $\quad$ Terceira folha trifoliolada (Michaelis, 1994).

R5: pré-florescimento (Michaelis, 1994).

$\mathrm{R}_{6}: \quad \quad$ Florescimento (Michaelis, 1994).

$\mathrm{R}_{7}$ : $\quad$ Formação das vagens (Michaelis, 1994).

R8: $\quad$ Enchimento das vagens (Michaelis, 1994).

$\mathrm{R}_{9}$ : $\quad$ Maturidade fisiológica (Michaelis, 1994). 


\title{
FERRUGEM E MANCHA ANGULAR DO FEIJOEIRO: EFEITO DE FUNGICIDAS NO DESENVOLVIMENTO DO HOSPEDEIRO E NO PROGRESSO DAS DOENÇAS
}

\author{
Autor: Nilceli Fernandes Buzzerio \\ Orientador: Prof. Dr. Armando Bergamin Filho
}

\section{RESUMO}

Foram conduzidos quatro experimentos com a cultivar 'Carioca' do feijoeiro (Phaseolus vulgaris), objetivando a possibilidade de implementação de um sistema de manejo integrado da ferrugem e mancha angular do feijoeiro após a intervenção com os fungicidas oxycarboxin (Hokko Plantvax 750 - 700 gramas/ha) e trifenil hidróxido de estanho (Mertin ${ }^{\circledR}-660 \mathrm{ml} / \mathrm{ha}$ ), respectivamente, aplicados em diferentes épocas. Foi realizada a quantificação de danos nesses patossistemas, verificando por meio de regressões lineares e não lineares as possíveis relações existentes entre as variáveis integrais $A U D P C$ (área sob a curva de progresso de doença), $H A D$ (duração da área foliar sadia) e $H A A$ (absorção da área foliar sadia) e suas correspondentes HLAI (índice de área foliar sadio) e HRI (absorção da área foliar por unidade de tempo) com a produção (gramas/planta). Os melhores resultados foram obtidos com as variáveis $H A D$ e $H A A$, com coeficientes de determinação $\left(\mathrm{R}^{2}\right)$ variáveis entre 0,19 e 0,56 para $H A D$ e 0,23 e 0,49 para $H A A$. Quando as variáveis $H L A I$ e $H R I$ foram relacionadas com a produção, os coeficientes de determinação variaram entre 0,24 e 0,57 para $H L A I$ e 0,28 e 0,56 para $H R I$. A partir das avaliações 
semanais de HLAI e HRI foram realizadas regressões lineares entre estas variáveis e a produção (gramas/planta). Os coeficientes angulares foram relacionados com os estádios de desenvolvimento observando-se a estabilização das curvas entre os estádios R5-R8 para o patossistema ferrugem - feijão e entre os estádios V4-R8 para o patossistema mancha angular - feijão para HLAI e HRI. Nesses experimentos foram também realizadas avaliações do Índice de Área Foliar $(L A I)$ utilizando-se medições diretas (avaliações manuais) e indiretas com ceptômetro. As medições obtidas com o este equipamento apresentaram sensibilidade suficiente para captar as variações no índice de área foliar sadio e portanto podem ser usadas em sistemas de manejo integrado da ferrugem e da mancha angular do feijoeiro. 


\title{
BEAN RUST AND ANGULAR LEAF SPOT OF BEAN: EFFECT OF FOLIAR FUNGICIDES ON THE HOST VEGETATIVE DEVELOPMENT OF HOST AND ON THE PROGRESS OF THE DISEASES
}

\author{
Author: Nilceli Fernandes Buzzerio \\ Adviser: Prof. Dr. Armando Bergamin Filho
}

\section{SUMMARY}

Four trials were carried out on dry beans (Phaseolus vulgaris), variety 'Carioca' with goal to verify the possibility of implementation of an integrated management system for rust and angular spot after the application with of oxycarboxin (Hokko Plantvax 750 - $700 \mathrm{~g} / \mathrm{ha}$ ) and trifenil stannic hydroxide $\left(\mathrm{Mertin}^{\circledR}-660 \mathrm{ml} / \mathrm{ha}\right.$ ) fungicides, applied in different timings. The damage quantification in these pathosystems were done analyzing the possible existing relation among the integral variables $A U P D C$ (Area Under Disease Progress Curve), $H A D$ (Healthy Area Duration) and $H A A$ (Healthy Area Absorption) and its correspondents HLAI (Healthy Leaf Area Index) and HRI (Healthy Radiation Intercept) with yield (grams/plant) through linear and non linear regression. The best results were obtained using the variables $H A D$ and $H A A$ with the determination coefficients $\left(\mathrm{R}^{2}\right)$ from 
0.19 to 0.56 for $H A D$ and 0.23 to 0.49 for $H A A$. When $H L A I$ and $H R I$ were related with yield, the determination coefficient ranged from 0.24 and 0.57 for HLAI and 0.28 to 0.56 for HRI. From weekly assessments of HLAI and HRI, linear regression analysis were done between those variables and yield (grams/plant). The angular coefficient were related with the different crop stages and the stability of curves was observed between R5-R8 stages for rust - dry bean pathosystem and between V4-V8 stages for angular spot - dry bean pathosystem when $H L A I$ and $H R I$ were analyzed. In these experiments, Leaf Area Indice (LAI) was also assessed with direct (manual) and indirect measures with a ceptometer. The measures obtained using this set provided necessary sensibility to catch $H L A I$ variation and, therefore, may be used in an integrated management system of rust and angular spot in dry beans. 


\section{INTRODUÇÃO}

Evidências oriundas do Novo Mundo indicam que o feijão (Phaseolus vulgaris L.) foi uma das primeiras plantas cultivadas pelo homem nas Américas, datando sua domesticação no México de 5.000 anos a.C. e no Peru a cerca de 3.000 anos a.C., pouco antes do aparecimento do milho nestas regiões (Fancelli, 1987).

É a principal leguminosa para o consumo humano (Voysest, 1983), principalmente nos países da América Latina e África devido ao seu alto teor protéico (22\%) (Vieira, 1988). A América Latina, em particular, é a zona de maior produção e consumo destacando-se dentre os países produtores o Brasil, considerado o maior produtor mundial (2,5 milhões de toneladas), constituindo-se por cerca de $20 \%$ do tipo preto e $80 \%$ do tipo cores. Os Estados de Paraná, Minas Gerais, Bahia e São Paulo são, em ordem crescente, os principais produtores do país (Di Stefano, 2000).

A maior parte do cultivo é ainda efetuado em caráter de subsistência por pequenos agricultores, entretanto devido aos fatores de mercado o feijão começou a ser cultivado também a nível empresarial, constituindo-se cerca de $15 \%$ da produção brasileira (450.000 toneladas) através do uso de pivô central (Menezes, 1994).

Apesar do Brasil ser um dos maiores produtores e consumidores de feijão do mundo, a cultura não apresenta grande produtividade no país devido ao baixo nível da tecnologia utilizada, ao empobrecimento do solo por culturas sucessivas e à ocorrência de pragas e doenças que podem assumir caráter epidêmico (Kimati, 1980). Bianchini et al. (1989) citam a existência de mais de 200 doenças capazes de afetar a cultura, limitando sua produção e reduzindo a qualidade fisiológica, sanitária, nutricional e comercial do produto. 
Dentre as doenças fúngicas que afetam o feijoeiro pode-se destacar a ferrugem (Uromyces appendiculatus Pers. Unger) e a mancha angular (Phaeoisariopsis griseola (Sacc.) Ferraris).

A ferrugem do feijoeiro provoca sintomas como amarelecimentos puntiformes, que se rompem quando as frutificações do fungo amadurecem. Esta doença afeta folhas, vagens, ramos e todas as demais porções verdes das plantas. A doença ocorre mundialmente, mas é mais comum em áreas tropicais e subtropicais. Severas epidemias ocorrem periodicamente em climas temperados úmidos, sendo rara em climas áridos. Os prejuízos na produção podem chegar a 100\% e estão diretamente relacionados à precocidade e severidade da infecção (Hall, 1991; Stavely, 1994).

Já a mancha angular do feijoeiro é a mais importante doença do feijoeiro em áreas tropicais e subtropicais, afetando várias regiões produtoras como a África, América Latina e Brasil (Beebe \& Pastor-Corrales, 1991; Saettler, 1994). Ela causa manchas necróticas nas folhas, afetando pecíolos, vagens e ramos, provocando reduções variáveis na produção entre 7 e $80 \%$, dependendo do local e ano dos experimentos (Schwart et al., 1982; Brenes, 1983; Sartorato \& Rava, 1992). É particularmente destrutiva em áreas onde a umidade e a temperatura são acompanhadas por um abundante inóculo proveniente de resíduos de plantas infectadas e sementes contaminadas (Saettler, 1994).

Os prejuízos reais, causados pela ferrugem e mancha angular do feijoeiro, podem variar de citação para citação, entretanto ainda não existem em literatura recomendações de controle das doenças baseadas nos danos que estas podem causar.

Para tanto, como pré-requisito para o desenvolvimento de qualquer programa bem sucedido de controle de doenças, faz-se necessário o conhecimento de estimativas confiáveis dos prejuízos causados pelos patógenos, sendo a quantificação de danos, portanto, um ponto chave na definição de qualquer estratégia de controle (Bergamin Filho \& Amorim, 1996), pois não se pode reduzir os prejuízos causados por uma doença a níveis aceitáveis sem se conhecer o dano causado por ela, além de não poder esperar a aplicação de recursos à pesquisa agropecuária na determinação de 
métodos de controle de doenças sem antes caracterizá-las (James, 1974; Campbell \& Madden, 1990). Deste modo, no contexto fitopatológico, a determinação dos prejuízos causados por fitopatógenos representa a definição do problema, e seria ilógico e certamente ineficiente buscar soluções para um problema que ainda não tenha sido definido (Bergamin Filho, 1995).

Novas abordagens foram propostas para a quantificação de danos como o hoje clássico artigo 'Desfoliation, disease and growth" de Waggoner \& Berger (1987). Estes autores propuseram o uso da duração da área foliar sadia (HAD - Healthy Area Duration - dias) e da absorção da área foliar sadia (HAA - Healthy Area Absorption - $\mathrm{MJ} \mathrm{m}^{-2}$ ) para estimar a redução da produção induzida pelas doenças.

Estas medições (HAD e $H A A)$ mostraram-se eficientes na determinação de danos na cultura do feijoeiro em diferentes patógenos (Lopes et al., 1994; Nunes, 1994; Amorim et al., 1995; Bergamin Filho, 1995; Nunes \& Bergamin Filho, 1996; Carneiro, 1995; Godoy, 1995; Iamauti, 1995; Bergamin Filho et al., 1997; Carneiro et al., 1997; Canteri, 1998; Canteri et al., 1998; Silva, 1997; Silva et al., 1998; Gianasi, 1999; Diaz, 2000).

Em outros patossistemas, estas variáveis também demonstraram potencial, como por exemplo, Greene \& Gorbet (1973), Nickle (1977), Mangold (1979), Wilkerson et al., (1984) e Pixley (1985), que trabalharam com o patossistema Cercosporidium personatum - amendoim; Carver \& Griffths (1982) com cevada Erysiphe graminis f.sp. hordei; Paveley et al., (1997), com o patossistema Septoria tritici - trigo; Rossing et al., (1992) com batata - Phytophthora infestans, dentre outros.

Além de estimar a possibilidade de decréscimo na produção, a quantificação de danos subsidia, com informações, o manejo das doenças (Campbell \& Madden, 1990). Esses modelos de avaliação de danos podem ser incorporados num sistema de manejo de doenças, o qual pode ser utilizado para prever o desenvolvimento da doença e prevenir a redução da produção através da utilização de medidas de controle (James \& Teng, 1990). Um modelo que capture a essência do efeito da doença sobre a produção permitirá, por exemplo, a determinação do limiar de dano econômico para o controle (Teng, 1987). 
Algumas dificuldades, porém, têm impedido a rápida proliferação de trabalhos nesta linha, já que as determinações das variáveis $H A D$ e $H A A$ são mais trabalhosas quando comparadas a medições de intensidade de doença $(x)$ (Canteri \& Giglioti, 1996), uma vez que esta é uma medida relativa, estimada geralmente com o auxílio de escalas diagramáticas, e aquelas, medidas absolutas que normalmente exigem a determinação real da área foliar Madden, 1983; Campbell \& Madden, 1990). Um segundo problema é devido ao relacionamento direto da intensidade da doença na produção ou dano da produção sem considerar a sua causa (Bastiaans et al., 1994). Também importante é a quantificação da desfolha promovida pela patógeno em estudo, o que pode ter impedido o estabelecimento da função de dano baseado na severidade da doença (Waggoner \& Berger, 1987). Outro ponto deficiente na adoção destes modelos é a falta de transportabilidade dos mesmos (Rouse, 1988).

Para tanto, este trabalho traz como objetivos principais:

- Estabelecer uma função de dano para a ferrugem e a mancha angular do feijoeiro, no cultivar Carioca, relacionando as variáveis integrais $A U D P C, H A D$ e $H A A$ e suas correspondentes HLAI e HRI com o componente da produção (gramas/planta);

- Avaliar o desenvolvimento do hospedeiro (em diferentes estádios de desenvolvimento), por meio do índice de área foliar sadio (HLAI), utilizando-se de medições diretas da área foliar e avaliar o progresso das doenças, após a intervenção com os fungicidas oxycarboxin (Hokko Plantvax 750 - 700 gramas/ha), para o controle da ferrugem e e trifenil hidróxido de estanho $\left(\right.$ Mertin $^{\circledR}$ - $660 \mathrm{ml} / \mathrm{ha}$ ) para o controle da mancha angular do feijoeiro;

- Estimar um limiar de dano econômico para os patossistemas ferrugem e mancha angular do feijoeiro;

- Comparar as medições dos índices de área foliar obtidos através de medições diretas da área foliar e medições indiretas utilizando-se de um ceptômetro. 


\section{REVISÃO DE LITERATURA}

\subsection{Ferrugem do Feijoeiro [Uromyces appendiculatus (Pers.:Pers.) Unger]}

\subsubsection{Etiologia e Morfologia}

Uromyces appendiculatus Pers. Unger é um Basidiomiceto da Ordem Uredinales que tem sido reportado infectando outras plantas de Phaseolus spp. e algumas espécies de Vigna (Stavely, 1994).

O fungo é um parasita obrigatório, macrocíclico e autóico. No entanto, picnidiósporos e aeciósporos são raramente vistos na natureza. Nas nossas condições, onde é possível o cultivo do feijoeiro durante praticamente todo o ano, o fungo sobrevive na fase uredial (Bianchini et al., 1997).

A infecção dos basidiósporos produz espermogônio (pícnia) na superfície adaxial das folhas. A pícnia aparece como um "flack" clorótico que aumenta em $2 \mathrm{~mm}$ de diâmetro, produzindo um néctar branco contendo os picnidiósporos. Após o movimento dos picnidiósporos para um pícnio de "matting type" oposto e fertilização cruzada, agrupamentos circulares (1-2 mm de diâmetro) de aécios brancos são formados na superfície abaxial das folhas. Os aécios produzem aeciósporos elipsoidais ou oblongos, poucos coloridos com aproximadamente 18-33 x 16-24 $\mu \mathrm{m}$. Os aeciósporos infectam as plantas de feijão para produzir as pústulas marromavermelhadas (Schwartz et al., 1990). Os urediniósporos medem 20-33 x 18-29 $\mu \mathrm{m}$ e são de coloração marrom-alaranjada, unicelulares, elipsóides ou globosos, medindo

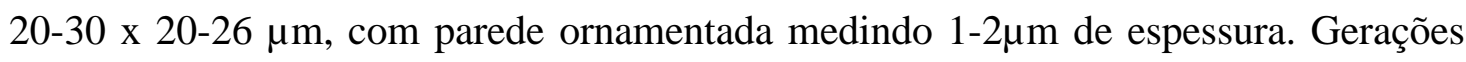
repetidas de urediniósporos ocorrem mais na estação de crescimento. Sob condições 
apropriadas e com o envelhecimento das uredínias são formados os teliósporos de coloração amarronzada (próximo a negros), de formato ovóide ou elipsoidal com dois núcleos com células dicarióticas fundidas, produzindo um grande núcleo diplóide, medindo 24-5 x 20-29 $\mu \mathrm{m}$ com espessura de parede entre 2-4 $\mu \mathrm{m}$. Imediatamente após a formação dos teliósporos, os dois núcleos com células dicarióticas fundem-se para produzir um núcleo diplóide grande. Posteriormente a um período de dormência, os teliósporos germinam para produzir um metabasídio, onde a meiose ocorre e onde são produzidos quatro basidiósporos unicelulares. Os basidiósporos são de formatos reniformes a oval-elíptico, lisos, hialinos medindo 5,8-11,4 x 10,7-20 $\mu \mathrm{m}$. Há poucas informações sobre a germinação dos teliósporos e produção dos pícnios e aécios, sendo estas porções do ciclo de vida raramente encontradas na natureza (Schwartz et al., 1990, Bianchini, et al. 1997).

\subsubsection{Sintomatologia}

A ferrugem do feijoeiro freqüentemente afeta folhas, mas também pode ser encontrada em vagens, ramos e todas as partes verdes das plantas de feijão. Os sinais mais comuns da ferrugem são as pústulas urediniais circulares de coloração marrom-avermelhada nas folhas ou vagens com ruptura da epiderme e produção abundante de urediniósporos. As pústulas podem variar em tamanho de um minúsculo ponto a 1-2 $\mathrm{mm}$ de diâmetro até grandes proporções. Inicialmente os sintomas aparecem com 5-6 dias após a infecção como uma diminuta e esbranquiçada mancha que se rompe entre 7-9 dias após a infecção, produzindo urediniósporos marromalaranjados. Poucas semanas depois, a produção de urediniósporos cessa gradualmente e teliósporos negros podem ser produzidos. Freqüentemente as pústulas são rodeadas por um halo de tecido amarelo (Stavely, 1994).

\subsubsection{Ocorrência e Importância}

A doença ocorre mundialmente, mas é mais comum em áreas tropicais e subtropicais úmidas. Severas epidemias ocorrem periodicamente em clima temperadoúmido e com raridade em climas áridos. Os danos na produção podem chegar a 100\% 
e estão diretamente relacionados à severidade precoce da infecção (Hall, 1991; Stavely, 1994). No entanto, estes dados são muito variáveis, não havendo consistência entre o nível de severidade da doença e os danos causados na produção (Godoy, 1995).

É considerada como um dos principais problemas que afeta a produção de feijão em muitas regiões da América Latina, incluindo o Brasil, Colômbia, México, e Peru (Schwartz \& Gálvez, 1980; Rios, 1994).

No Brasil com o surgimento da terceira época de plantio, a do "inverno" (semeaduras de janeiro a agosto), houve um despertar no interesse dos médios e grandes produtores com a ocorrência da ferrugem e principalmente devido às condições climáticas características desta época de plantio, diferentes das épocas tradicionais, a das "águas" (semeadura de outubro a novembro) e a das "secas" (semeaduras de janeiro a março). Na época do "inverno", o clima mais ameno e a elevada umidade, devido à irrigação, contribuem para o desenvolvimento da doença (Bulisani, 1990; Vieira, 1994).

Uromyces appendiculatus está entre o mais variável de todos os patógenos de planta, possuindo mais de 250 raças em todo o mundo diferindo quanto à virulência em cultivares de feijão (Menezes, 1994).

\subsubsection{Epidemiologia e Controle da Doença}

Os urediniósporos são disseminados pelo homem, implementos, animais e principalmente pelo vento (Menezes, 1994). Podem sobreviver entre as estações de cultivo, iniciando nova epidemia quando as condições são favoráveis. A penetração dá-se pelos estômatos, após o tubo germinativo entrar em contato com as células estomáticas e desenvolver apressório. A germinação dos urediniósporos dá-se entre 68 horas de período de umidade e entre $16-25^{\circ} \mathrm{C}$ de temperatura, não ocorrendo em temperaturas acima de $28{ }^{\circ} \mathrm{C}$. Temperaturas abaixo de $15{ }^{\circ} \mathrm{C}$ retardam o desenvolvimento da esporulação nas pústulas estendendo-se por 7 dias à temperatura ótima de $24{ }^{\circ} \mathrm{C}$ e por 9 dias à $16{ }^{\circ} \mathrm{C}$. Temperaturas prolongadas maiores que $32{ }^{\circ} \mathrm{C}$ podem matar o fungo. Produções abundantes de urediniósporos são favorecida por alta 
umidade abaixo do ponto de saturação, dias longos e tecidos vigorosos do hospedeiro (Stavely, 1994; Menezes, 1994).

A eficiência da esporulação varia inversamente com a densidade uredinal. O tamanho uredinal (pústulas) também decresce com a alta intensidade das infecções (Bianchini et al., 1997).

As condições ideais para o desenvolvimento da infecção da ferrugem são a temperatura entre $17-27^{\circ} \mathrm{C}$ e umidade relativa maior que $95 \%$ por $10-18$ horas (Bianchini et al., 1997).

É considerada uma doença de juros compostos de ciclo secundário, pois pode desenvolver diversas gerações da doença durante o mesmo ciclo do hospedeiro, (Vanderplank, 1963), de tal forma que uma planta infectada no início de seu ciclo servirá como fonte de inóculo para posteriores infecções do patógeno no mesmo ciclo da cultura.

As recomendações para o controle da ferrugem do feijoeiro incluem práticas culturais como a rotação de culturas e eliminação de restos culturais visando a diminuição do inóculo inicial até o uso de variedades resistentes como IAPAR-14, IAC-Maravilha, IAC-Una, Ouro Negro, Vermelho-2157, Ouro, Meia Noite, Rudá e Aporé, Uirapuru e tendem a diminuir a taxa de aumento da doença (Vanderplank, 1963; Schwartz \& Gálvez, 1980; Bianchini et al., 1997). Vale ressaltar que muitas variedades são resistentes a poucas raças do patógeno. A redução quanto ao número de pústulas é uma forma de resistência algumas vezes observada. Períodos latentes longos tem sido reportados, mas usualmente estão associados com o tamanho da pústula (Stavely, 1994).

Pompeu et al. (1988), estudando a produtividade de diferentes cultivares de feijão no Estado de São Paulo, concluíram que os cultivares Ayso, Carioca 80, Moruna 80 e Aroana 80 tiveram uma boa produção além de serem considerados resistentes a doenças como a ferrugem, já o cultivar Carioca foi considerado susceptível. 
$\mathrm{O}$ ajuste da época de plantio de modo a minimizar a exposição da cultura a longos períodos de umidade e temperaturas favoráveis à infecção pode efetivamente reduzir a incidência da doença em muitos locais (Stavely, 1994).

O controle químico deve ser realizado com o aparecimento das primeiras pústulas, em regiões de alta incidência. Produtos como oxycarboxin, bitertanol, tebuconazole, triforine são eficientes no controle da doença (Kimati et al. 1997). O inseticida Cartap tem ação preventiva, curativa e erradicante sobre a ferrugem do feijoeiro (Ito et al., 1994; Ito et al, 1996). Já o mancozeb apresentou uma ação preventiva para o controle da ferrugem do feijoeiro, porém com uma pequena ação curativa (Sartorato et al., 1983)

Ainda não se conhece em literatura recomendações de controle baseadas nos danos que possam ser ocasionados pela ferrugem do feijoeiro.

\subsection{Mancha Angular do Feijoeiro (Phaeoisariopsis griseola (Sacc.) Ferraris}

\subsubsection{Etiologia e morfologia}

A mancha angular do feijoeiro é causada por Phaeoisariopsis griseola (Sacc.) Ferraris. Foi descrita pela primeira vez por Saccardo em 1878 como Isariopsis griseola. Em 1909, Ferraris concluiu que o gênero Isariopsis era sinonímia do gênero Phaeoisariopsis, propondo então a denominação de fungo Phaeoisariopsis griseola para o patógeno (Zaumeyer \& Thomas, 1957).

O fungo produz os conidióforos em grupos (sinêmio) de 8 a $40 \mu \mathrm{m}$, ostentando conídios acinzentados, cilíndricos e fusiformes, às vezes curvos, com 2-6

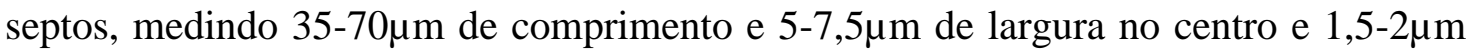
de largura na base (Bianchini et al., 1997).

O patógeno exibe variabilidade quanto a patogenicidade e 14 patotipos tem sido identificados mundialmente. O fungo é capaz de infectar várias culturas, incluindo o feijão comum, feijão lima, feijão "scarlet runner", feijão "tepary", ervilha, "cowpea", Vigna angularis (Willd) Ohwi \& H. Ohashi e Vigna umbrellata (Thunb.) Ohwi \& H. Ohashi (Ferraz, 1980). 


\subsubsection{Sintomatologia}

A mancha angular apresenta sintomas típicos de lesões necróticas delimitadas pelas nervuras em folhas trifolioladas. No campo geralmente são observados logo após o florescimento ou quando as plantas atingem a maturidade. Os danos maiores na cultura resultam na desfolha precoce ocasionada pela doença, ocorrendo de forma generalizada em folhas, vagens e hastes, sendo mais facilmente identificada nas folhas. A esporulação pode ocorrer em lesões em vagens, folhas, pecíolos ou ramos sob condições de umidade prolongada (Kulik, 1984).

Nas folhas primárias, as lesões são geralmente circulares, de coloração castanha ou marrom-acinzentada, já nas folhas trifolioladas, as lesões aparecem como manchas angulares de coloração marrom ou acinzentada de aproximadamente 0,30 a $0,63 \mathrm{~cm}$ de diâmetro rodeada por um halo amarelo, delimitadas pelas nervuras. Em condições favoráveis observa-se na face inferior dos folíolos, pontuações negras formadas pelos sinêmios do fungo (Zaumeyer \& Thomas, 1957; Ferraz, 1980).

Nos pecíolos e ramos as lesões são alongadas e de coloração marrom escuro ou marrom-avermelhada. Nas vagens as lesões são ovais, circulares de aproximadamente 1,22 $\mathrm{cm}$ de coloração marrom-avermelhada, apresentando bordos escuros, facilmente confundidas com aquelas causadas pelo crestamento bacteriano, especialmente em culturas mais velhas. As vagens infectadas podem produzir sementes pouco desenvolvidas ou totalmente enrugadas (Ferraz, 1980; Saettler, 1994).

A esporulação em vagens, hastes e lesões no pecíolo ocorrem após 2448 horas de umidade contínua ou condições de umidade prolongada (Saettler, 1994).

\subsubsection{Ocorrência e Importância}

A mancha angular é de ocorrência mundial tanto em regiões tropicais como sub-tropicais, entretanto possui características mais próximas do patossistema tropical, ou seja, é mais dependente da quantidade de inóculo do que das condições climáticas (Canteri, 1998).

Citam-se como países de ocorrência a Colômbia, Argentina, Brasil, Costa Rica, Guatemala, México, Peru, Venezuela, Estados Unidos, Austrália, Índia, 
Irã, Japão, Israel, além de países da África e Europa (Zaumeyer \& Thomas, 1957; Ellis et al., 1976; Ferraz, 1980). Na África, especialmente, o controle desta doença é a maior prioridade do programa nacional na região (Pyndji \& Trutmann, 1992).

No Brasil esta doença já foi considerada como secundária (Costa, 1972;

Vieira, 1988), entretanto atualmente vêm se tornando importante (Beebe \& PastorCorrales, 1991). As razões para essa mudança são ainda desconhecidas, acreditando-se que o plantio de materiais suscetíveis aliado a um ambiente favorável tenham proporcionado condições ideais ao seu desenvolvimento (Sartorato, 1988) e provavelmente responsáveis pelo aumento nos danos causados por esta doença (Godoy, 1995).

A mancha angular é mais comum nas safras das secas, com semeaduras realizadas entre os meses de janeiro a março (Rodrigues et al., 1999).

\subsubsection{Epidemiologia e Controle da Doença}

Os conídios de Phaeoisariopsis griseola germinam na superfície das folhas e as hifas penetram através dos estômatos desenvolvendo-se no espaço intercelular do parênquima foliar. A partir do $9^{\circ}$ dia o desenvolvimento do fungo dá-se intracelularmente no tecido necrótico, sendo o estroma formado a partir do $10^{\circ}$ ao $12^{\circ}$ dias na cavidade sub-estromática. $\mathrm{O}$ sinêmio é formado em presença de alta umidade, sendo à $25^{\circ} \mathrm{C}$ a temperatura ótima para o seu desenvolvimento. Já para a formação dos conídios as temperaturas de 15,20 e $25{ }^{\circ} \mathrm{C}$ com ótimo de $25{ }^{\circ} \mathrm{C}$ foram citadas por (Cardona-Alvarez \& Walker, 1956).

Tanto a infecção quanto à doença são favorecidas a $16-28{ }^{\circ} \mathrm{C}$, com desenvolvimento máximo à temperatura de $24{ }^{\circ} \mathrm{C}$. Sintomas no campo são geralmente observadas logo após a floração ou em plantas próximas a maturidade. A maioria dos prejuízos causados resultam na desfolha prematura (Cardona-Alvarez \& Walker, 1956; Saettler, 1994).

A disseminação dos conídios são responsáveis pelo desenvolvimento do ciclo secundário da doença. Eles são disseminados pelo vento, partículas de solo infestadas e respingos de chuva, sendo que a liberação dos conídios ocorre melhor na 
ausência de chuva (Cardona-Alvarez \& Walker, 1956). O fungo sobrevive em sementes e restos culturais por períodos entre 10 meses e 2 anos (Cardona-Alvarez \& Walker, 1956; Correa \& Saettler, 1986).

A fonte de inóculo primário do patógeno incluem sementes contaminadas e restos de plantas infectadas. Em ambos os casos, os conídios produzidos são disseminados através do vento, chuva, respingos ou ambos. As sementes podem apresentar contaminação externa ou interna. Contaminações externas em sementes de "red kidney" estão associadas ao desenvolvimento do fungo apenas na região do hilo, quando essas estão localizadas abaixo das lesões das vagens. Em outros tipos de feijões, o desenvolvimento do patógeno pode ser tanto no hilo como em outros locais da casca das sementes. O nível de infecção de $P$. griseola nas sementes varia entre os cultivares e a sua viabilidade com o tempo (Dhingra \& Kushalappa, 1980; Saettler, 1994).

Quanto à esporulação, esta ocorre durante períodos de alta umidade. Para a germinação dos conídios, Cardona-Alvarez \& Walker (1956) concluíram que as temperaturas entre 8 e $32{ }^{\circ} \mathrm{C}$, com ótimo entre $20-28{ }^{\circ} \mathrm{C}$ são necessárias, além de um período mínimo de 3 horas de molhamento.

Além do Phaseolus vulgaris, Phaeoisariopsis griseola também ataca Phaseolus lunatus (Cardona-Alvarez \& Walker, 1956) além de P. coccineous, $P$. angularis, $P$. acutifolius e $P$. calcaratus, sendo estes últimos infectados artificialmente por Campos \& Fucikovsky (1980).

Também importante para o desenvolvimento de epidemias, pode-se citar o sistema de cultivo, além dos períodos de alta umidade relativa, suficientemente longos (24-48 horas), alternados por períodos de baixa umidade, ação dos ventos e temperatura entre $15,5-27,7^{\circ} \mathrm{C}$ (Kulik, 1984). Em condições controladas a máxima severidade ocorreu na faixa de temperatura entre $21-25{ }^{\circ} \mathrm{C}$ e o menor período de incubação a $25^{\circ} \mathrm{C}$. Já o período infeccioso e a colonização foram favorecidos pela temperatura de $24^{\circ} \mathrm{C}$ e a taxa de crescimento das lesões aumentaram à $25^{\circ} \mathrm{C}$. Quanto ao período de molhamento, o mínimo requerido foi de 6 horas para que o processo de infecção iniciasse, já que a severidade da doença é altamente influenciada por este 
fator (Dalla Pria, 1997). Combinando-se dados de temperatura e duração do molhamento foliar, Dalla Pria (1997) concluiu que a severidade da mancha angular do feijoeiro aumenta à medida que aumenta também o período de molhamento quando associada a faixa de temperatura entre 21 e $25^{\circ} \mathrm{C}$.

Para o controle desta doença têm-se recomendado o uso de sementes sadias, eliminação dos restos culturais infectados, rotação de culturas para permitir a eliminação do inóculo presente na área (Bianchini et al., 1989) e o uso de resistência varietal. Até o momento são poucas as variedades com bom nível de resistência, a obtenção de materiais com alto nível de resistência é dificultada pelo grande número de raças fisiológicas do fungo (Sartorato, 1988). As variedades que apresentam melhor reação ao patógeno são Aporé, Ouro, Diamante Negro e Uirapuru (Bianchini et al., 1997).

O controle químico também é indicado (Issa et al., 1982; Tanaka \& Junqueira Neto, 1982; Castro et al., 1989; Goulart, 1990; Oliveira et al., 1992; Canteri, 1998), apesar de ainda não se conhecer recomendações de controle baseadas nos danos que possam ser ocasionados pela doença. Atualmente tem-se recomendado o controle preventivo, utilizando-se de duas a três aplicações, de acordo com o histórico de ocorrência da doença (Menezes, 1994).

Produtos como o trifenil acetato de estanho, trifenil hidróxido de estanho, tebuconazole e chorothalonil são recomendados (Menezes, 1994). Barros \& Castro (2000), recomendam a mistura de fungicidas fluquinconazole + fentin hidróxido, azoxystrobin + chlorothalonil, tetraconazole + tiofanato metílico. Ito et al. (2000a e b), recomendam também o uso da mistura trifenil hidróxido de estanho + fluquinconazole, além de azoxystrobin e imibenconazole + trifenil acetato de estanho. Já fungicidas a base de mancozeb apresentaram ação preventiva eficiente, porém com uma pequena ação curativa (Sartorato et al., 1983). Ito et al. (1994) estudando o efeito do Cartap concluíram que este inseticida reduz a severidade da mancha angular.

\subsection{Quantificação de Danos}

As doenças de plantas começaram a ser estudadas inicialmente em função do dano que causavam, entretanto ainda hoje poucas são as estimativas 
confiáveis de danos causadas por patógenos. A ausência destas relações foi o fator que mais retardou o progresso do manejo de doenças de plantas (James, 1974), pois não basta apenas afirmar que uma doença leva a perdas, deve-se saber a magnitude deste dano para se poder correlacionar com o ganho obtido e conseqüentemente desenvolver métodos de controle de doenças econômicos e racionais dentro de um manejo de doenças de plantas. Somente após a relação doença-dano estar estabelecida, é possível determinar as perdas econômicas devido a diferentes intensidades de doença (James, 1974; James \& Teng, 1979).

Para tanto, de acordo com a FAO (1968), o controle integrado de doenças pode ser definido como um sistema de manejo de doenças que utiliza todas as técnicas disponíveis para manter as doenças abaixo do limiar de dano. Dentre esses métodos utilizados, alguns são definidos antes da instalação da cultura, como por exemplo, a escolha do cultivar, outros precisam ser decididos durante o crescimento da cultura, como a escolha do fungicida e a época de sua aplicação. Neste caso, a decisão necessita de informações como a previsão do crescimento da doença durante o ciclo e as perdas que poderão advir se o controle não for efetuado, além da relação custobenefício para cada tratamento.

Estas informações requerem a quantificação de danos, já que estabelece a função de dano requerida pelo manejo integrado. Entretanto, para se quantificar o dano, faz-se necessário a avaliação da injúria causada pela doença que no contexto fitopatológico pode ser traduzida por incidência ou severidade da doença, e o dano decorrente dessa injúria como reduções quantitativas da produção (Iamauti, 1995).

O parâmetro incidência é o de maior precisão, simplicidade e facilidade de obtenção e pode ser definido como a porcentagem de plantas, ou de seus órgãos, doentes em uma população. Do ponto de vista epidemiológico, a incidência expressa em porcentagem, pode ser utilizada na elaboração de curvas de progresso de doenças. Quando a epidemia está em sua fase inicial, a incidência é um parâmetro satisfatório para a avaliar a maioria das doenças, uma vez que nesta fase pode ser correlacionada à severidade (Amorim et al., 1995). 
Já a severidade é definida como a área de tecido foliar afetado pela doença, expressa com relação à proporção total de área. Sua aplicabilidade é maior no caso de doenças foliares, já que se encontra muito ligada à produtividade e, conseqüentemente aos danos causados pelas doenças (James, 1974; Kranz, 1988).

Tem-se ainda, um termo mais geral usado para a quantificação de doenças, a intensidade, que pode se referir tanto à incidência como a severidade (Chiarappa, 1971).

$\mathrm{Na}$ determinação da severidade tem-se utilizado chaves descritivas, escalas diagramáticas, análise de imagem e sensoriamento remoto (James, 1974; James \& Teng, 1979; Gaunt, 1987; Kranz, 1988).

Dentre estes métodos, o uso de escalas diagramáticas é o mais utilizado (Amorim \& Bergamin Filho, 1991) devido ao menor custo despendido e a facilidade no uso, já os métodos de sensoriamento remoto apesar de serem práticos, possuem maior rapidez e precisão nas avaliações, entretanto o seu custo elevado vem retardando a sua utilização maciça.

\subsubsection{Modelos para a Estimativa de Danos}

Para se estudar a relação doença-dano, modelos matemáticos são utilizados (Campbell \& Madden, 1990).

Zadoks $^{1}$ (1973), (citado por Bastiaans, 1994), reviu a tentativa de relacionar redução de danos com doença e categorizou então o modelo de ponto crítico, múltiplos pontos e modelos integrais. Modelos de ponto crítico e múltiplos pontos usualmente relacionam dano com severidade da doença em apenas um estágio de crescimento da cultura ou em vários estágios, respectivamente. Já modelos integrais usualmente relacionam produção com a área sob a curva de progresso da doença (Area Under the Disease Progress Curve - $A U D P C$ ), por exemplo. Todos estes modelos são usados para deduzir funções de danos empíricas através de análises de regressão com dados de campo (Bastiaans, 1994; Bergamin Filho et al., 1995).

${ }^{1}$ ZADOKS, J.C. Modelling the models. Introduction to Symposium: Developing Models for Measuring of Crop Losses (Handdout). 2nd International Congress of Plant Pathology, Minneapolis, 1973. 
Teng (1985), sugeriu que estes modelos fossem classificados como empíricos, explanatórios e conceituais. O modelo empírico é o mais amplamente aplicado para avaliação de danos e desenvolvido a partir de dados experimentais. Simulação de danos requer modelos explanatórios, e os conceituais utilizam o conhecimento existente da fisiologia vegetal e os efeitos da doença na produção para formular prováveis respostas.

\subsection{Avaliação de Danos através da Área Foliar Fotossintetizante}

Os modelos de ponto crítico, múltiplos pontos e modelos integrais não possuem elementos mecanísticos ou explanatórios (Fleming \& Bruhn, 1983² ; Rossing et al., 1992 ${ }^{3}$, citados por Bergamin Filho \& Amorim, 1996), já que relacionam diretamente a medida da intensidade da doença na produção ou dano na produção, sem considerar a sua causa. São portanto específicos a determinadas condições (tempo, localização e cultivar) (Bastiaans et al., 1994), não passando, portanto no teste de transportabilidade (Rouse, 1988).

Entretanto, a partir dos anos 80, maior atenção vem sendo dada à relação dano na produção com a resposta fisiológica da planta (Gaunt, 1981; Madden, 1983), pois sem ela não seria possível uma completa compreensão do processo de dano e, portanto o estabelecimento de estratégias adequadas de manejo de doenças (Boote et al., 1983).

O parâmetro área foliar total e também o índice de área foliar lLAI Leaf Area Index) (relação entre metros quadrados de área foliar por metro quadrado de solo) são mais comumente utilizados, já que descrevem e explicam diferenças no potencial de crescimento de plantas submetidas a diferentes tratamentos, podendo ser inclusive correlacionados com produção (Gaunt, 1981).

Waggoner \& Berger em 1987, reforçaram esta idéia e sugeriram que a lógica da relação entre severidade da doença e produção é incerta em virtude de não

\footnotetext{
${ }^{2}$ FLEMING, R.A. \& BRUHN, J.A. The role of mathematical models in plant health management. In: Challenging problems in plant heath. Kommdahl, T. \& Williams, P.H., ed APS Press, St. Paul. 368-378, 1983.

${ }^{3}$ ROSSING, W.A.H.; van OIJEN, M.; van der Werf, W.; BASTIAANS \& RABBINGE, R. Modeling the effects of foliar pests and pathogens on light interception, photosynthesis, growth rate and yield of field crops. In: Pests
} 
haver relação para todas as doenças, com exceções encontradas por Schneider et al. (1976); Lim (1980) e Broscious et al. (1987), além de que a severidade da doença tem efeito diferente, caso ocorra precoce ou tardiamente no ciclo da cultura e porque a desfolha não é considerada nas avaliações de severidade.

Estes autores lembraram ainda que já em 1947, Watson havia encontrado alta correlação entre produção e índice de área foliar (LAI). Este autor propôs que a produção correlacionava-se ainda melhor com a duração da área foliar (LAD - Leaf Area Duration), definida como a integral em função do tempo do índice de área foliar, de acordo com a equação:

$$
L A D=\sum_{i=1}^{n o-1}\left(\left(L A I_{i}+L A I_{i+1}\right) / 2\right)\left(t_{i+1}-t_{i}\right)
$$

onde $L A D$ é a duração da área foliar (expressa em dias), $L A I_{i}$, o índice de área foliar no tempo $t_{i}$ (sem dimensão) e $t$, o tempo.

Outras pesquisas como as desenvolvida por Monteith (1981) e CharlesEdwards (1982), refinaram as hipóteses de Watson (1947).

A lei de Beer, citada por Waggoner \& Berger (1987), expressa a relação entre a isolação transmitida $\left(I \mathrm{em} \mathrm{MJ} \mathrm{m}^{-2}\right.$ ) através da folhagem, isto é a fração absorvida RI é dada por:

$$
R I=[1-\exp (-\mathrm{k} L A I)]
$$

sendo k o coeficiente de extinção, valor próximo a um para plantas com folhas horizontais e ao redor de 0,3 para plantas eretas. Para o feijoeiro, Miglioranza (1992) determinou experimentalmente que o valor médio de k é de 0,7.

Portanto a produção está mais relacionada com a quantidade de energia absorvida pela folha do que com $L A D$. Para tanto, Lopes et al., (1994) propuseram o termo absorção da área foliar (LAA - Leaf Area Absorption), definida pela equação:

$$
L A A=\sum_{i=1}^{n o-1} I\left[\left(1-\exp \left(-k L A I_{i}\right)\right)+\left(1-\exp \left(-k L A I_{i+1}\right)\right)\right] / 2\left(t_{i+1}-t_{i}\right)
$$

A partir dessas explanações, pode-se compreender o porque dos muitos resultados desapontadores. Os fitopatologistas estavam mais preocupados com o 
patógeno do que com o hospedeiro, isto é relacionavam doença com produção, não com a radiação absorvida pelas folhas, esta fundamental para a produção da matéria seca.

Como elucidam Waggoner \& Berger (1987), o LAD é a soma do índice de área foliar em função do tempo e $L A A$ é a soma da fração de insolação absorvida multiplicada pela própria insolação em função do tempo. Essas variáveis ( $L A D$ e $L A A)$ fornecem informações a respeito do tamanho da folhagem, quanto tempo ela persiste e quanta radiação ela absorve (Iamauti, 1995).

Baseados nos conceitos fisiológicos desenvolvidos por Watson (1947) e refinados por Gallagher \& Biscoe (1978) e Monteith \& Elston (1983), é possível verificar os efeitos da doença sobre a folhagem do hospedeiro. Para isso basta subtrair a área foliar doente da duração da área foliar $(L A D)$. Isto se faz por meio da integração da área foliar sadia e operacional durante o período de crescimento do hospedeiro [(1y)LAI]. Esta integração resulta no que Waggoner \& Berger (1987) chamam de duração da área foliar sadia (HAD - Healthy Area Duration) (dias) é calculada por

$$
H A D=\sum_{i=1}^{n o-1}\left[L A I_{i}\left(1-y_{i}\right)+L A I_{i+1}\left(1-y_{i+1}\right)\right] / 2\left(t_{i+1}-t_{i}\right)
$$

De igual forma, pode-se realizar esta adaptação à variável absorção da área foliar ( $L A A)$. A equação proposta na equação 3 gera o que Waggoner \& Berger (1987) chamaram de absorção da área foliar sadia (HAA - Healthy Area Absorption), expressa em $\mathrm{MJ} \mathrm{m}^{-2}$.

$$
H A A=\sum_{i=1}^{n-1} I\left[\left(1-y_{i}\right)\left(1-\exp \left(-k L A I_{i}\right)\right)+\left(1-y_{i+1}\right)\left(1-\exp \left(-k L A I_{i+1}\right)\right)\right] / 2\left(t_{i+1}-t_{i}\right)
$$

Embora recente e trabalhosa, a abordagem proposta por Waggoner \& Berger (1987) tem trazido o desenvolvimento de vários artigos científicos, que relacionaram as variáveis duração da área foliar sadia $(H A D)$ ou absorção da área foliar sadia $(H A A)$ com produção. 
Trabalhos como os de Carver \& Griffths (1982) (cevada - Erysiphe graminis f.sp. hordei; Madeira et al. (1988) (Vicia faba - Ascochyta fabae); Subba Rao et al. (1989) (trigo - Puccinia recondita f.sp. tritici); Johnson \& Teng (1990) (batata Alternaria solani); Oijen, (1990); Rossing et al., (1992) (batata - Phytophthora infestans); Aquino et al. (1992) (amendoim - Cercosporidium personatum); Ferrandino \& Elmer, (1992) (tomateiro - Septoria lycopersici); Yang et al., (1992) (soja Phakopsora pachyrhizi); Carneiro (1995) (feijão - Phaeoisariopsis griseola); Godoy (1995) (feijão - Phaeoisariopsis griseola); Iamauti (1995) (feijão - Uromyces appendiculatus); Nunes \& Bergamin Filho (1996) (feijão - Colletotrichum lindemuthianum); Paveley et al. (1997) (trigo - Septoria tritici); Canteri, (1998) (feijão - Phaeoisariopsis griseola), Silva et al. (1998) (feijão - Phaeoisariopsis griseola, Uromyces appendiculatus, Colletotrichum lindemuthianum); Carneiro et al. (2000) (feijão - Phaeoisariopsis griseola), Gianasi (1999) (feijão - Colletotrichum lindemuthianum); Diaz (2000) (feijão - Xanthomonas axonopodis f.sp. phaseoli), dentre outros, podem exemplificar o uso destas variáveis.

Como consideraram Madden (1983) e Campbell \& Madden (1990), estas estimativas ( $H A D$ e $H A A)$ não atingiram estudos em grandes proporções devido à dificuldade na determinação de trabalhos nesta linha, já que a determinação da intensidade de doença $(x)$, uma medida relativa estimada geralmente com o auxílio de escalas diagramáticas, é menos trabalhosa que aquelas medidas absolutas que, normalmente exigem a determinação real da área foliar.

Esta dificuldade tem impedido, até aqui, o emprego de $H A D$ e $H A A$ em sistemas de manejo integrado de doenças. Entretanto, atualmente este obstáculo já está sendo superado graças ao aperfeiçoamento das técnicas de sensoriamento remoto (Lopes et al., 1994).

\subsection{Manejo Integrado de Doenças}

Antes de iniciar as definições sobre manejo integrado, faz-se necessária à descrição de alguns termos utilizados neste contexto. Zadoks (1985) define organismo nocivo como qualquer agente biológico que danifique uma plantação. 
Produção, como o produto mensurável de valor econômico de uma plantação. Qualquer sintoma causado por um organismo nocivo é injúria e a redução na quantidade e/ou qualidade da produção é chamada de dano. A redução em retorno financeiro, por unidade de área, devido à ação de organismos nocivos é chamada de perda.

Desta forma, manejo integrado pode ser definido como a utilização de todas as técnicas disponíveis dentro de um programa unificado, de tal modo a manter a população de organismos nocivos abaixo do limiar de dano econômico e a minimizar os efeitos colaterais deletérios ao meio ambiente (NAS, 1969).

Sistemas de manejo integrado procuram fazer com que a produção atual de uma área se aproxime ao máximo da produção econômica, com a menor agressão possível ao homem e ao meio ambiente (Bergamin Filho \& Amorim, 1996). A produção econômica pode ser definida como o nível de produção em que há maior lucro para o agricultor (Zadoks \& Schein, 1979). Sua definição não é fácil, pois os preços dos produtos variam conforme as leis de mercado e os subsídios governamentais, entre outros fatores. A aplicação prática dos sistemas de manejo integrado depende de estudos sobre o limiar de dano econômico e de considerações sobre custo/benefício, para cada patossistema (Gianasi, 1999).

O emprego do manejo integrado implica na determinação do limiar de dano econômico (LDE), definido como "a densidade populacional do organismo nocivo na qual o benefício do controle iguala ao seu custo" (Munford \& Norton 1984). Além do LDE outros limiares são importantes para a implementação de programas de manejo integrado de doenças, conforme descrito por Bergamin Filho \& Amorim (1996): o limiar de ação (Zadoks \& Schein, 1979), definido como "a menor densidade populacional do organismo nocivo na qual táticas de manejo necessitam ser tomadas para impedir que o LDE seja alcançado" e o limiar biológico de dano (LBD) (Morse \& Buhler, 1997), definido como "a menor densidade populacional do organismo nocivo que ocasiona diminuição na produção".

O LDE não é estático e imutável (Canteri et al., 1998). Exemplos para seu cálculo podem ser encontrados em Bergamin Filho \& Amorim (1996). A 
dificuldade para calculá-lo é um dos motivos da pequena quantidade de trabalhos com aplicações práticas sobre o assunto, apesar do LDE ser a pedra fundamental do manejo integrado de doença (Zadoks, 1985). Dentre as razões para isto, percebe-se, segundo Bergamin Filho (1995), a incerteza avaliada na relação doença-dano já discutida anteriormente.

\subsubsection{O LDE e as variáveis $H A D$ e $H A A$}

Um dos objetivos principais a ser alcançado com o desenvolvimento da abordagem de quantificação de danos para o limiar de dano econômico é a criação de um sistema transportável capaz de produzir recomendações precisas e exatas a nível de propriedade, especialmente adaptado às condições tropicais e subtropicais (Bergamin et al., 1995).

Dois de seus componentes relacionam-se diretamente com esse objetivo, o primeiro já bastante discutido é a variável explanatória absorção da área foliar sadia (HAA), o segundo é a utilização da parcela controle (PC), livre de doença, indispensável para cada situação de produção (SP) e responsável pela transportabilidade do sistema (Lopes et al., 1994).

A execução dessa abordagem, permitirá definir um limiar de dano econômico, mais estável, baseado nas variáveis explanatórias $H A D$ e $H A A$ relacionadas com produção (Lopes et al., 1994), que utilizando ensaios apropriados de campo, permitirão o estabelecimento da relação entre a diminuição da $H A D$ ou $H A A$ e a respectiva diminuição da produção (Bergamin et al., 1995).

A partir dessa relação, e contando com informações sobre a eficiência das possíveis medidas de controle, incluindo a recuperação de $H A D$ ou $H A A$, e sobre os custos e benefícios envolvidos, chega-se à determinação do novo limiar de dano econômico $\left(\mathrm{LDE}_{H A D}\right.$ ou $\left.\mathrm{LDE}_{H A A}\right)$ agora não mais expresso em porcentagem de doença, ambos de relação incerta com produção, mas sim em unidades de $H A D$ (dias) ou $H A A$ $\left(\mathrm{MJ} \mathrm{m}^{-2}\right)$. 
A partir dessas informações, as medidas de controle só serão recomendadas pelo sistema de manejo integrado de doenças quando a variação de $H A D$ for superior ao $\mathrm{LDE}_{H A D}$.

Assim, $\Delta_{H A D}=H A D_{\mathrm{PC}}-H A D_{\mathrm{SP}}$ ou quando a variação de $H A D$ for superior ao $\mathrm{LDE}_{\mathrm{HAD}} \cdot$

Assim, $\Delta_{H A A}=H A A_{\mathrm{PC}}-H A A_{\mathrm{SP}}$, onde $H A D_{\mathrm{PC}}$ ou $H A A_{\mathrm{PC}}$ é a estimativa na parcela controle e $H A D_{\mathrm{SP}}$ ou $H A A_{\mathrm{SP}}$ é a estimativa de $H A D$ ou $H A A$ estimados na situação de produção considerada.

A recomendação de qual produto aplicar ou que medida de controle empregar dependerá do patógeno, ou patógenos envolvidos na situação de produção de $H A D$ ou $H A A$.

Além de $H A D$ e $H A A$ há outras variáveis sugeridas por Madden \& Nutter Jr. (1995), de mais fácil quantificação que poderá ser aplicada em sistemas de manejo integrado, são as variáveis índice de área foliar sadio (HLAI - Healthy Leaf Area Index) e a radiação interceptada pela área foliar sadia por unidade de tempo (HRI - Healthy Radiation Intercepted). O mesmo raciocínio acima descrito pode ser adotado (Bergamin Filho \& Amorim, 1995).

De acordo com as sugestões de Madden \& Nutter Jr. (1995), Bergamin Filho et al. (1997) demonstraram que os coeficientes angulares da regressão entre a produção do feijoeiro e $H L A I$ e $H R I$, apresentavam-se muito variáveis no estádio de crescimento $V_{3}$ de Michaels (1994) e tenderam a estabilizar-se entre os estádios de crescimento $R_{5}-R_{8}$. Esta estabilização permitiu sua utilização como uma variável chave no sistema de manejo de doenças. Eles verificaram que tal estabilização deu-se ao redor de 26,8 $\mathrm{g} \mathrm{MJ}^{-1}$, o que significa que para cada unidade de $H R I$ ocorreu um incremento de $268 \mathrm{~kg}$ ha, se considerarmos 200.000 planta ha. Tem-se que o custo de controle de doenças no feijoeiro seja da ordem de US\$ 40 ha e que este valor equivale a aproximadamente $96 \mathrm{~kg}$ de feijão. Este custo de $96 \mathrm{~kg}$ ha equivale a aproximadamente $1 / 3$ do benefício advindo do controle que é $268 \mathrm{~kg}$ ha $(96 / 268=0,36)$. Deste modo, tem-se que quando a diferença entre o HRI no sistema 
produtivo e a parcela controle for de $1 / 3$ da unidade, já se recomenda o controle, ou seja, tem-se grosseiramente o nível de dano em 1/3 de HRI. Lembrando-se que a variável quantificada a nível de campo e utilizada para cálculo do HRI é HLAI, são necessários acurácias da ordem de 1/20 unidade HLAI para culturas de feijão com HLAI de $0,2,1 / 10$ para $1,2,1 / 5$ para $2,2,1 / 3$ para $2,9,1 / 2,5$ para $3,2,1 / 2$ para 3,5 e $1 / 1$ para 4,5 (valores calculados para radiação média de $\mathrm{I}=12,0 \mathrm{MJ} \mathrm{m}^{-2}$ e $\mathrm{K}=0,7$ ).

Resultados semelhantes foram observados por Bergamin Filho \& Amorim (1996), entretanto, os autores utilizaram para cálculo do limiar de dano o HLAI e obtiveram como resultado que o limiar de dano estaria ao redor de 1/8 de HLAI.

Gianasi (1999) utilizou o mesmo raciocínio de Bergamin Filho et al. (1997) e encontrou que o limiar de dano econômico para o patossistema antracnose feijão é de $1 / 4$ de unidade de $H R I$, significando que a diferença entre a parcela controle e a situação de produção não poderia atingir $1 / 4$ de unidade de $H R I$.

Embora praticamente seja menos morosa a determinação do HLAI ao nível de extensionista e/ou produtor, quando comparada ao HRI, HLAI tem a desvantagem de ser influenciada pelo sistema de produção (Bergamin Filho et al., 1997).

Níveis de dano mais refinados somente poderão ser estabelecidos após o reconhecimento de qual é o efeito de medidas de controle sobre $H L A I$ e $H R I$, o que atualmente na literatura é extremamente deficiente (Bergamin Filho \& Amorim, 1996).

Alguns trabalhos têm demonstrado que os valores de HRI e HLAI tornam-se maiores em sistemas onde são utilizados defensivos comparados ao sistema sem uso (Lim \& Gaunt, 1981; Rawlinson et al., 1984; Madeira et al., 1988; Aquino et al., 1992; Bourgeois \& Boote, 1992).

Finalmente, a implantação do manejo de doenças baseada em $H R I$ ou HLAI até então esbarrava na dificuldade de obtenção dos dados de área foliar e severidade de doença. Essas atividades demandam grande trabalho, o que vinha dificultando sua implementação. Entretanto, atualmente com o uso de técnicas de sensoriamento remoto esta demanda vem sendo reduzida. 


\subsection{Sensoriamento Remoto}

O conjunto de técnicas capazes de obter informações de um objeto sem que haja contato físico com este foi denominado por Jackson (1986) de sensoriamento remoto. São medidas não destrutivas e não invasivas de um objeto específico, podendo ser analisado muitas vezes sem danificação da amostra (Nilsson, 1995).

São muitos os equipamentos e técnicas disponíveis nos estudos de sensoriamento remoto, podendo-se citar as estimativas visuais (Richardoson et al., 1975), radiômetros de múltiplo espectro (Chiang \& Wallen, 1977); fotografias aéreas (Mannering \& Johnson, 1969) além de ceptômetros e barras de interceptação de luz (ACCUPar, s.d.).

Informações obtidas em folhas individuais fornecem dados sobre os mecanismos das transformações ocorridas dentro da planta, entretanto, para se obter alguma aplicação prática, necessita-se estende-la para o nível do dossel em condições de campo (Hatfield, 1990).

Informações da arquitetura do dossel são essenciais para descrever diferentes mecanismos como o da radiação interceptada (Ross, 1981), o da interceptação da precipitação (Norman \& Campbell, 1989), da produtividade da cultura (de Wilt, 1965), dentre outros.

A arquitetura do dossel de uma planta é função do arranjamento espacial dos órgãos aéreos que em conjunto formam a copa das plantas. Folhas e outros órgãos que realizam fotossíntese atuam como coletoras de energia solar, deste modo, a arquitetura do dossel afeta a quantidade e qualidade da radiação solar que é refletida, transmitida ou absorvida (Hatfield, 1990; Nutter Jr. \& Littrell, 1996).

Em geral, a estrutura do dossel refere à distribuição da posição, orientação, forma e área de vários órgãos da planta (folhas, flores, ramos, etc.). O desenvolvimento recente das técnicas matemáticas tem trazido descrições detalhadas da arquitetura do dossel. Estas técnicas utilizam-se da densidade dedutiva da folhagem e o ângulo de distribuição das folhas através das medições das frações de abertura das mesmas. Freqüentemente medições da estrutura do dossel incluem o índice de área 
foliar ( $L A I$ ), densidade foliar (área da folhagem por unidade de volume do dossel) e algumas medições de como os elementos da folhagem estão orientados, como o ângulo de distribuição das folhas ou o ângulo de inclinação das folhas (Welles \& Norman, 1991).

Os métodos de estimativa indireta do $L A I$ são baseados em medições da transmissão de luz através da camada do dossel. Este método é menos tedioso e laborioso.

Campbell \& Norman (1989) estudaram algumas técnicas diretas para estimar o LAI e o ângulo de distribuição foliar. O erro associado com a dificuldade em medir amostragens individuais e espaciais levaram a procura de um método para estimar as características da arquitetura do dossel. Técnicas indiretas baseadas na união entre a penetração da radiação e a estrutura do dossel trouxe uma alternativa. As medições das frações das aberturas do dossel (a fração visível através do dossel) em vários ângulos é particularmente um sucesso (Campbell \& Norman, 1989).

Vale ressaltar que a estrutura do dossel é dinâmica durante a estação de crescimento, com alterações na população de folhas, que geralmente aumenta durante o ciclo da cultura, a não ser que seja anulada pela desfolha que pode ser provocada pelo patógeno, pela alimentação de insetos ou pela própria senescência da planta (Nutter Jr. \& Littrell, 1996). Deste modo, a arquitetura obtida pelo "stand" no campo e a quantidade de produção são funções do crescimento da planta através do tempo. Este processo geralmente é de difícil mensuração, porque tanto o crescimento do hospedeiro como a quantificação da severidade de doença demandam grande intensidade de trabalho. A taxa de crescimento das plantas geralmente é proporcional à quantidade de radiação interceptada pelas suas copas, deste modo o HLAI e o HRI juntamente com suas intergrais $H A D$ e $H A A$ apresentam alta correlação com a produção (Waggoner \& Berger, 1987).

Pode-se citar alguns equipamentos que utilizam estes parâmetros de medições, são as barras métricas (Miller, 1967), LAI - 2000 Plant Canopy Analyzer (LI-COR) (Martens \& Rosseau, 1993; Oplustilova et al. 1995); os GEOSCAN (Portable Field Spectroradiometer -PFS) (Smith et al., 1993); os Sunfleck Ceptometer 
(Chen et al., 1997), as barras de interceptação de luz (Armbrust, 1990); os Ceptômetros ou barras de desfolha (Degacon, USA - Oplustilova et al., 1995), dentre outros.

A cobertura do dossel, isto é, a porcentagem da superfície do solo coberta pelas folhas das plantas, é freqüentemente utilizada em estudos de fotossíntese transpiração e erosão provocada pela água ou vento, estresses provocados pela água na cultura, eficácia de fertilizantes e pesticidas bem como avaliação do efeito das doenças (ACCUPar, s.d; Armbrust, 1990; Martins, 1994).

Alguns métodos extremamente laboriosos e algumas vezes também destrutivos requerem remoção das folhas das plantas para posterior secagem e pesagem de forma a obter estimativas de produtividade (coca - Erythroxylum spp). (Acock et al., 1994). Outros, parcialmente laboriosos e destrutivos (avaliação de subamostras de folhas), alternativamente, estimam a massa foliar usando uma área específica da área foliar (SLA - Specific Leaf Area) que nada mais é que a transformação da proporção de área foliar em massa foliar (Acock et al., 1994).

Existem diferentes equipamentos de interceptação de luz, também chamados de ceptômetros ou barra de desfolha, dentre eles o LAI - 2000 Plant Canopy Analyzer (LI-COR), que mede a luz difusa por diferentes ângulos zenitais simultaneamente. Cada sensor possui cinco anéis concêntricos detectores de luz que recebem a radiação de diferentes setores do céu nos ângulos de $7,23,38,53$ e 68 , além da possibilidade de agrupamento de todos os cinco ângulos zenitais para medições de luz direta ao invés da difusa. A proporção de níveis de luz medidas acima e abaixo do dossel oferece a transmitância para cada setor do céu (Chason et al., 1991).

Outro equipamento é o Light Interception - Crop \& Timber Canopy (ACCUPar - DECAGON), mais conhecido como barra de desfolha ou ceptômetro. Este equipamento possui uma barra com 82 centímetros de comprimento, 10 milímetros de largura x 15 milímetros de altura, contendo 80 sensores sensíveis à luz distribuídos a cada 1 centímetro (Armbrust, 1990), que medem a radiação fotossinteticamente ativa (PAR) nos comprimentos de onda de 400 a $700 \mathrm{~nm}$ e indiretamente o índice de área foliar (ACCUPar, s.d.). 
Estudos comparativos efetuados por Armbrust (1990), entre o método eletrônico ceptômetro (Sunfleck Ceptometer - DECAGON) e barra métrica foram correlacionadas através de medições do dossel de trigo (Triticum aestivum L.), milho (Zea mays L.) e soja (Glycine max ). O autor comprovou que ambos os métodos produziram estimativas semelhanças de cobertura do dossel das plantas, entretanto o ceptômetro foi o de mais fácil utilização do que o método de barra métrica, especialmente para dosséis de pequenos grãos e gramíneas.

Os ceptômetros ou barras de desfolha, demonstraram potencial na estimativa rápida e precisa do índice de área foliar ( $L A I)$, pois ofereceram alto grau de confiabilidade, medições não destrutivas e a possibilidade de efetuar um grande número de leituras em curto espaço de tempo além da conversão em índice de área foliar (Campbell \& Norman, 1989), que associado ao ângulo de distribuição das folhas pode prever a produtividade de determinadas culturas (Lang, 1987). 


\section{MATERIAL E MÉTODOS}

\subsection{Instalação dos Ensaios em Campo}

Foram instalados quatro experimentos, entre os anos agrícolas de 1998 a 2000, no campo experimental do Departamento de Entomologia, Fitopatologia e Zoologia Agrícola da Escola Superior de Agricultura "Luiz de Queiroz - ESALQ/USP, em Piracicaba, São Paulo.

Em todos os plantios, instalados no primeiro semestre dos anos agrícolas de 1998 e 1999 para o patossistema ferrugem - feijão (safra de inverno) e segundo semestre dos anos agrícolas de 1998 e 1999 para o patossistema mancha angular - feijão (safra das águas e seca, respectivamente), foram utilizados o cultivar 'carioca' (lote IT 128/97) fornecido pelo Instituto Agronômico de Campinas (IAC CATI).

$\mathrm{O}$ primeiro experimento (C1) e o terceiro (C3), destinados à quantificação do efeito do fungicida oxycarboxin no desenvolvimento do hospedeiro (feijão) e no progresso da doença (ferrugem), foram instalados no dia 26/06/98 e 07/06/99, respectivamente. Já o segundo (C2) e o quarto (C4) experimentos, destinados à quantificação do efeito do fungicida trifenil hidróxido de estanho no desenvolvimento do hospedeiro (feijão) e no progresso da doença (mancha angular) foram instalados no dia 06/11/98 e 10/01/00, respectivamente.

As semeaduras foram realizadas manualmente em sulcos que receberam $350 \mathrm{~kg} / \mathrm{ha}$ da fórmula 4-14-8 na adubação de plantio e $200 \mathrm{~kg} / \mathrm{ha}$ de sulfato de amônio na adubação de cobertura, aos 22 dias após a germinação. A manutenção dos experimentos deu-se por meio de práticas culturais convencionais, seguindo-se as 
práticas agronômicas atuais recomendadas à cultura. A suplementação hídrica foi realizada a partir de irrigações durante o período requerido, mediante aspersores instalados na área cultivada, com uma lâmina d'agua aplicada de 25-30 mm e em turno de rega de três dias.

Quando necessário realizou-se pulverizações com inseticida methamidophos (1,25 litro p.c./ha), a partir dos 15 dias após a emergência. e deltametrin (100 mL/100 L de água) para se obter controle de insetos como vaquinhas tripes, etc.

\subsection{Avaliações do Desenvolvimento do Hospedeiro, Severidade da Doença e Produção}

Para todos os experimentos, utilizou-se o mesmo delineamento experimental, o de blocos ao acaso, com cinco tratamentos e doze repetições. Cada parcela possuía $8 \mathrm{~m}^{2}$, sendo composta por quatro linhas de plantio (duas linhas úteis e duas de bordadura), espaçadas em 0,50 metros, procurando-se obter em média a densidade de 10 plantas por metro linear, através de desbaste realizado aos 25 DAP (dias após o plantio). Após o desbaste as plantas foram contadas para obter o "stand" inicial das parcelas e no dia da colheita as plantas foram recontadas para se saber o "stand" final das parcelas, de modo a ser utilizado para cálculo da produção por parcela.

Cada parcela foi dividida em duas partes, sendo a primeira metade (1S) destinada às medições manuais da área foliar e porcentagem da severidade da doença e a segunda metade $(2 \mathrm{~S})$ foi destinada às medições com o ceptômetro. Esta subdivisão de parcelas teve como objetivo evitar os danos nas plantas que seriam avaliadas com o ceptômetro.

A metodologia de avaliação utilizada foi a de plantas individuais (Hau et al., 1980), onde na primeira metade da parcela (1S) foram selecionadas quatro plantas semelhantes em tamanho e vigor, duas a cada uma das linhas centrais, num total de sessenta plantas por experimento. Estas plantas foram marcadas no surgimento do primeiro par de folhas trifolioladas [(estádio de desenvolvimento V3 da escala descrita por Michaelis (1994)]. 
Durante todo o ciclo da cultura, foram realizadas avaliações semanais do desenvolvimento do hospedeiro mediante medições da maior largura do folíolo central $(\mathrm{L}=\mathrm{cm})$ de todo os trifólios de todas as plantas marcadas. Estes dados foram transformados em área foliar $\left(\mathrm{LA}=\mathrm{cm}^{2}\right)$ através da equação proposta por Bassanezi (1995), com um coeficiente de determinação $\left(\mathrm{R}^{2}\right)=0,88$ :

$$
\mathrm{LA}=3,03 L^{1,87}
$$

De igual forma, foram realizadas avaliações semanais da porcentagem de severidade da doença, utilizando-se de escalas diagramáticas da ferrugem (experimentos C1 e C3) e da mancha angular (experimentos C2 e C4) desenvolvidas por Godoy et al. (1997) (Figuras 1 e 2), com as quais foram avaliadas a porcentagem média da severidade para todos os trifólios de todas as plantas marcadas.

Os primeiros sinais da ferrugem provocados por Uromyces appendiculatus do experimento $\mathrm{C} 1$ foram observados aos 34 dias após o plantio (DAP) para o experimento $\mathrm{C} 1$ e aos 38 DAP para o experimento C3. As avaliações da severidade da doença foram realizadas aos 34, 41, 48, 55, 62, 69, 76, 83 e 92 dias após o plantio (DAP) (C1) e aos 38, 46, 52, 67, 73, 81, 88 e 94 DAP para o experimento C3. Já os primeiros sintomas da mancha angular, causado por Phaeoisariopsis griseola foram observados aos 27 DAP para o experimento C2 e aos 31 DAP para o experimento C4. As avaliações do experimento C2 foram realizadas aos 27, 34, 41, 46, 53, 62 e 69 DAP e aos 31, 39, 44, 52, 60, 66, 73, 78 e 85 DAP para o experimento C4.

Para cada experimento foram realizadas duas inoculações com intervalo de dez dias, iniciadas quando as plantas apresentavam o segundo par de folhas trifolioladas totalmente expandidas [entre o estádio $V_{3}$ e $V_{4}$ (Michaelis, 1994)] e a segunda após 10 dias isto é aos 34 e 44 DAP para os experimentos C1 e C3 (ferrugem - oxycarboxin) e aos 25-35 DAP e 35-45 DAP respectivamente para os experimentos C2 e C4 (mancha angular - trifenil hidróxido de estanho). As concentrações médias foram de $10^{5}$ urediniósporos/ml para os experimentos com ferrugem e de $10^{5}$ conídios/ml para os experimentos com mancha angular. 
Essas suspensões foram pulverizadas sobre todas as plantas nas duas linhas centrais de cada parcela, utilizando-se pulverizador costal de pressão constante (40 Lb/pol 2 ), aplicando-se em média $150 \mathrm{ml}$ de suspensão para cada tratamento, com exceção do tratamento 5 (T5). As inoculações iniciavam-se sempre após as 19:00 horas sendo que, previamente, as plantas recebiam quinze minutos de aspersão com água de irrigação, de forma a proporcionar molhamento foliar, indispensável para o desenvolvimento das doenças.

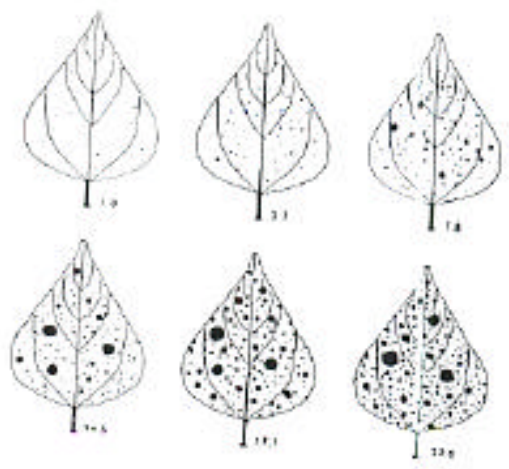

Figura 1 - Escala diagramática da severidade (porcentagem de área foliar afetada) da ferrugem do feijoeiro, causada por Uromyces appendiculatus (Godoy, et al., 1997). Piracicaba, São Paulo, 1998 - 2000.

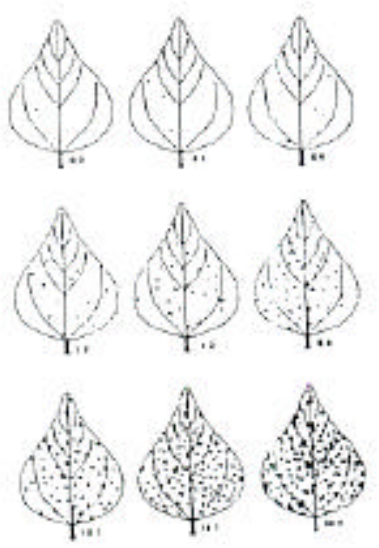

Figura 2 - Escala diagramática da severidade (porcentagem de área foliar afetada) da mancha angular do feijoeiro, causada por Phaeoisariopsis griseola (Godoy, et al., 1997). Piracicaba, São Paulo, 1998 - 2000. 
Paraproporcionar diferentes níveis de severidade das doenças, foram realizadas pulverizações com fungicidas à base de oxycarbonix $(0,5-0,8 \mathrm{Kg} / \mathrm{há}) \mathrm{e}$ trifenil hidróxido de estanho (325 - $1000 \mathrm{ml} / \mathrm{ha})$ para o controle da ferrugem e da mancha angular do feijoeiro e em diferentes épocas (Tabela 1 e 2).

Tabela 1. Características dos defensivos agrícolas utilizados nos experimentos com a ferrugem $(\mathrm{C} 1, \mathrm{C} 3)$ e com a mancha angular $(\mathrm{C} 2, \mathrm{C} 4)$ do feijoeiro. Piracicaba, São Paulo, 1998 - 2000.

\begin{tabular}{llll}
\hline \multicolumn{1}{c}{ Produto técnico } & Produto comercial (pc) & \multicolumn{1}{c}{ Dosagem (pc) } & Fabricante \\
\hline Oxycarboxin & Hokko Plantvax 750 & 700 gramas/ha & Hokko do Brasil S.A \\
trifenil hidróxido de estanho & Mertin $400^{\oplus}$ & $660 \mathrm{ml} / \mathrm{ha}$ & Syngenta Prot. Cultivos Ltda. \\
\hline
\end{tabular}

Tabela 2. Descrição dos tratamentos realizados nos experimentos com a ferrugem $(\mathrm{C} 1$, C3) e com a mancha angular (C2, C4) do feijoeiro. Piracicaba, São Paulo, 1998 - 2000.

\begin{tabular}{cl}
\hline Tratamentos & \\
\hline T1 & Sem pulverização com fungicida e com duas inoculações artificiais em intervalo de 10 \\
& dias; \\
T2 & Primeira pulverização no estádio R5 1 (pré-floração) e repetida uma única vez após 14 dias \\
& com duas inoculações artificiais em intervalo de 10 dias; \\
T3 & Primeira pulverização iniciada no estádio R6 (floração) e repetida uma única vez após 14 \\
& dias com duas inoculações artificiais em intervalo de 10 dias; \\
T4 & Pulverização iniciada no estádio R5 (pré-floração) e continuada a cada 14 dias até as \\
& plantas terem atingido o estádio R6 (floração) com duas inoculações artificiais em \\
& intervalo de 10 dias; \\
Aplicações semanais com fungicida e sem inoculação artificial.
\end{tabular}

${ }^{1}$ Michaelis (1994)

As observações climáticas como a precipitação pluvial (mm) e o número total de dias com precipitação, a temperatura mínima, máxima e média além da porcentagem de umidade relativa do período entre as avaliações dos experimentos 
C1, C2, C3 e C4 foram obtidas de uma Estação Meteorológica localizada no Departamento de Ciências Exatas da Escola Superior de Agricultura "Luiz de Queiroz - ESALQ/USP, em Piracicaba, São Paulo, cujas coordenadas são: Latitude 22 42'30" sul; :Longitude: $47^{\circ} 38^{\prime} 30^{\prime \prime}$ oeste e altitude de 546 metros.

A desfolha do hospedeiro foi quantificada simultaneamente durante as avaliações da área foliar $\left(\mathrm{cm}^{2}\right)$ e severidade $(\%)$.

Para cálculo da produção, as colheitas de todos os experimentos foram realizadas quando a maioria das vagens atingiram a maturação fisiológica [(estádio R9: início da senescência a completa senescência (Michaelis, 1994)]. Foram colhidas separadamente as plantas marcadas das duas linhas centrais de cada parcela, numa área útil de $8 \mathrm{~m} 2$ de forma a padronizar a densidade de plantas por metro quadrado e avaliados os componentes da produção: número de vagens viáveis por planta, número total de sementes e peso de sementes por planta. Para o cálculo da produção por parcela foram contadas ("stand" final) e colhidas as duas linhas centrais de cada parcela de forma a padronizar a densidade de plantas por metro quadrado. Após a colheita, procedeu-se à secagem do material colhido ao ar livre até que as sementes atingissem 12\% de umidade (Marcos Filho et al., 1987), com posterior debulha e pesagem dos grãos. 


\section{RESULTADOS E DISCUSSÃO}

\subsection{Forma de análise dos resultados}

\subsubsection{Cálculo da área sob a curva de progresso da doença (AUDPC)}

A partir dos dados de área foliar $\left(\mathrm{cm}^{2}\right)$ de cada trifólio obtidos de medições da maior largura do folíolo central, foi realizada uma somatória da área foliar total e da severidade de cada planta. Estes dados foram utilizados no cálculo da área foliar doente da planta (transformação da severidade estimada em porcentagem) isto é, área foliar doente subtraída da área foliar total $\left(\mathrm{cm}^{2}\right)$.

Obtidos estes valores procedeu-se ao cálculo da área sob a curva de progresso da doença $(A U D P C)$, calculada por integração trapezoidal (Shaner \& Finney, 1977), através da equação:

$$
A U D P C=\sum_{i=1}^{n-1}\left[\left(X_{i}+X_{i+1}\right) / 2\right]\left(t_{i+1}-t_{i}\right)
$$

onde $X$ é a severidade média da doença por planta (porcentagem), $X_{i}=x\left(t_{i}\right), n$ é o número de avaliações e $\left(t_{i+1}-t_{i}\right)$ é o intervalo entre duas avaliações consecutivas.

O cálculo do Índice de Área Foliar (LAI) de cada planta foi obtido de acordo com a equação:

$$
L A I=\mathrm{AFm} / 10.000 / 0,0417
$$

onde AFm é a área foliar média obtida de cada planta

Estes dados foram utilizados para o cálculo da absorção da área foliar sadia $(H A D)$ para cada planta, calculada através da equação:

$$
H A D=\sum_{i=1}^{n-1}\left\{\left[L A I_{i}\left(1-X_{i}\right)+L A I_{i+1}\left(1-X_{i+1}\right)\right] / 2\right\}\left(t_{i+1}-t_{i}\right)
$$


onde $L A I_{i}=L A I\left(t_{i}\right) . \mathrm{O}$ valor do índice de área foliar sadio $(H L A I)$ para cada planta e em cada avaliação foi calculado de acordo com a equação:

$H L A I=L A I(1-X)$

Os valores de radiação interceptada $\left(R I_{i}\right)$ em $\mathrm{MJ} \mathrm{m}^{-2}$ foram calculados de acordo com a equação

$$
R I_{i}=I_{i}\left[1-\exp \left(-k L A I_{i}\right)\right]
$$

em que $I_{i}$ é a média de radiação solar incidente $\left(\mathrm{MJ} \mathrm{m}^{-2}\right)$ no período $\left(t_{i+1}-t_{i}\right)$ e $k$ é o coeficiente de extinção [ $k=0,7$ (Miglioranza, 1992)].

Já os valores da absorção da área foliar sadia $(H A A)$ em $\mathrm{MJ} \mathrm{m}^{-2}$ para cada planta foi calculado a partir da equação:

$$
H A A=\sum_{i=1}^{n-1} I_{i}\left(\left\{\left(1-X_{i}\right)\left[1-\exp \left(-k L A I_{i}\right)\right]+\left(1-X_{i+1}\right)\left[1-\exp \left(-k L A I_{i+1}\right)\right]\right\} / 2\right)\left(t_{i+1}-t_{i}\right)
$$

Os valores da radiação interceptada pela área foliar sadia $\left(H R I, M J \mathrm{~m}^{-2}\right)$ para planta e data de avaliação foi calculado através da equação:

$H R I=R I(1-X)$

A radiação solar incidente $(I)$ foi medida por uma Estação Meteorológica computadorizada situada no Departamento de Ciências Exatas da ESALQ/USP, cujas coordenadas são: Latitute: $22^{\circ} 42^{\prime} 30^{\prime \prime}$ sul; Longitude: $47^{\circ} 38^{\prime}$ 30' oeste; Altitude 546 metros.

\subsubsection{Porcentagem de Desfolha}

Os dados de desfolha foram utilizados para cálculo da porcentagem de desfolha (DF, \%) tomando-se como referência a área foliar total das plantas, através da equação:

$$
\mathrm{DF}=(\text { Área desfolhada/Área foliar total }) * 100
$$

\subsubsection{Produção}

A produção foi estimada pelo método de planta individual, onde se obteve os dados dos componentes da produção: no. de vagens viáveis por planta, no. de sementes viáveis por planta e produção em gramas/planta. 
Também foram obtidas a produção por parcela a partir da contagem final do "stand" da parcela de forma a estimar a densidade de plantas por metro quadrado.

Os dados obtidos da área sob a curva de progresso da doença (AUDPC), índice de área foliar sadio (HLAI), duração da área foliar sadia $(H A D)$, radiação interceptada pela área foliar sadia por unidade de tempo $(H R I)$, absorção da área foliar sadia $(H A A)$, porcentagem de desfolha e número de folhas emitidas de todos os experimentos ( $\mathrm{C} 1, \mathrm{C} 2, \mathrm{C} 3$ e $\mathrm{C} 4)$ foram submetidos a análise de variância e comparação de médias entre os tratamentos através do teste de Tukey a $5 \%$ de probabilidade através do software Plot-It For Windows (Scientic Programming Enterprises, Haslett, MI).

Os dados da produção (gramas/planta) foram relacionados com AUDPC, HLAI, HAD, HRI, HAA e porcentagem de desfolha. Posteriormente realizouse análise de regressão linear e não linear (software Statistica - StatSoft, Tulsa, E.U.A.), de forma a verificar a tendência dos dados obtidos. Também foram realizadas análises conjuntas dos dados dos quatro experimentos com as variáveis HLAI, HAD, $H R I$ e $H A A$, de forma a obter uma única equação que representasse todos os experimentos. Foram realizadas também regressões lineares com passagem forçada através da origem entre os dados da produção (gramas/planta) e as variáveis HLAI e $H R I$ e os coeficientes angulares obtidos foram relacionados com os estádios de crescimento do feijoeiro (Michaelis, 1994), de forma a verificar a estabilização dos dados e posteriormente calcular o limiar de dano econômico para estas variáveis.

A colheita do experimento $\mathrm{C} 1$ foi realizada aos 80 DAP para o tratamento T1 e aos 95 DAP para os demais tratamentos. Para o experimento C2 a colheita foi realizada aos 68 DAP para o tratamento T1 e aos 76 DAP para os demais tratamentos. Já para o experimento C3, a colheita foi realizada aos 86 DAP para o tratamento T1 e aos 101 DAP para os demais tratamentos. No experimento C4 a colheita foi realizada aos 78 DAP para o tratamento T1 e aos 87 DAP para os demais tratamentos. 


\subsubsection{Dados obtidos com o Ceptômetro}

Foram realizadas avaliações semanais (subparcela 2S) com um ceptômetro (Light Interception - Crop \& Timber Canopy - ACCUPar - DECAGON), que mede a radiação fotossinteticamente ativa (PAR) nos comprimentos de onda de 400 a $700 \mathrm{~nm}$ e indiretamente o índice de área foliar (LAI). Procurou-se padronizar o horário das avaliações (sempre próximo ao meio dia solar) e a radiação incidente ao sol entre 1200 -1400 de forma a minimizar os possíveis fatores de interferência nas leituras.

A partir das medições do índice de área foliar obtidas com o ceptômetro, fez-se primeiramente, uma média das seis leituras por tratamento e posteriormente relacionou-se os gráficos comparativos entre o LAI obtido manualmente (LAI Manual) com o LAI obtido com o ceptômetro (LAI Ceptômetro) de forma a verificar se o $L A I$ obtido com o ceptômetro conseguiu capturar as variações ocorridas do índice de área foliar durante o decorrer dos experimentos. Posteriormente o LAI obtido manualmente (LAI manual) foi relacionado com o LAI obtido com o ceptômetro (LAI ceptômetro) e realizada regressão linear com passagem forçada através da origem, de forma a verificar, através do coeficiente de determinação $\left(\mathrm{R}^{2}\right)$, se o ceptômetro pode ser viável em sistemas de manejo integrado de doenças do feijoeiro na estimativa de variáveis como HLAI, HAD e HAA.

\subsection{Dados Climáticos e Radiação Solar}

Os dados climáticos e de radiação solar dos experimentos $\mathrm{C} 1, \mathrm{C} 2$, C3 e C4 estão representados nas Tabelas 3, 4, 5 e 6 respectivamente.

A temperatura média durante a condução dos experimentos $\mathrm{C} 1$ e $\mathrm{C} 3$ (ferrugem - oxycarboxin), ficou em torno de $19,83^{\circ} \mathrm{C}$ e $20,05^{\circ} \mathrm{C}$, respectivamente, temperaturas estas dentro dos limites ideais para o desenvolvimento da ferrugem do feijoeiro (Bianchini et al., 1997). Temperaturas acima de $24{ }^{\circ} \mathrm{C}$ reduzem a severidade da ferrugem mesmo sob período adequado de molhamento foliar (Mendes \& Bergamin Filho, 1989). Já a porcentagem de umidade relativa média destes experimentos ficou em torno de 76,74\% e 67,75\% respectivamente aos experimentos $\mathrm{C} 1$ e $\mathrm{C} 3$, valores 
estes inferiores à umidade relativa ideal ao desenvolvimento da infecção desta doença, isto é umidade relativa maior que 95\% (Bianchini et al., 1997). Vale \& Zambolim (1996), estudando a ferrugem do feijoeiro concluíram que o número de horas em que as plantas permanecem molhadas não parece ser mais importante do que a temperatura para infecção de Uromyces appendiculatus. A precipitação média durante a condução destes experimentos foi de 12,5 e 9,36 mm respectivamente, aos experimentos C1 e C3 (Tabelas 3 e 5).

Observa-se nas Tabelas 4 e 6 que a temperatura média durante a condução dos experimentos C2 e C4 (mancha angular - trifenil hidróxido de estanho), ficou em torno de $24,32^{\circ} \mathrm{C}$ e $24,21^{\circ} \mathrm{C}$, respectivamente, temperaturas estas dentro dos limites ideais, segundo Kulik (1984), para o desenvolvimento da mancha angular do feijoeiro. Já a porcentagem da umidade relativa média destes experimentos ficou em torno de $84,44 \%$ e $84,25 \%$ respectivamente aos experimentos $\mathrm{C} 2$ e $\mathrm{C} 4$, valores estes suficientes para o desenvolvimento da doença (Kulik, 1984).

Com relação aos dados de precipitação, pode-se notar que em todos os intervalos das avaliações houve períodos de chuva, condição esta que aliada à irrigação por aspersão são importantes no desenvolvimento da mancha angular e na ocorrência de epidemias (Vale \& Zambolim, 1996; Rodrigues et al., 1999).

De modo geral as condições climáticas foram favoráveis ao desenvolvimento da ferrugem e mancha angular do feijoeiro durante o decorrer dos experimentos. 
Tabela 3. Dados climáticos realizados durante a execução do experimento C1 (ferrugem - oxycarboxin). Piracicaba, São Paulo, 1998 - 2000.

\begin{tabular}{|c|c|c|c|c|c|c|c|}
\hline \multirow[t]{2}{*}{ Mês/ Ano } & \multirow[t]{2}{*}{$\mathrm{DAP}^{1}$} & \multicolumn{2}{|c|}{ Precipitação } & \multicolumn{3}{|c|}{ Temperatura $\left({ }^{\circ} \mathrm{C}\right)$} & \multirow{2}{*}{$\begin{array}{c}\text { UR } \\
\%\end{array}$} \\
\hline & & $\mathrm{mm}$ & $\begin{array}{c}\text { No. de } \\
\text { dias }\end{array}$ & Mínima & Máxima & Média & \\
\hline $06 / 98$ & 34 & 0,4 & 2 & 10,6 & 25,7 & 18,2 & 81,5 \\
\hline $07 / 98$ & 41 & 1,9 & 3 & 11,6 & 24,8 & 18,2 & 82,4 \\
\hline 08/98 & 48 & 0,5 & 1 & 14,1 & 24,3 & 19,2 & 88,2 \\
\hline 08/98 & 55 & 0,5 & 1 & 16,2 & 29,9 & 23,1 & 76,1 \\
\hline $08 / 98$ & 62 & 0 & 0 & 14,8 & 31,1 & 23,0 & 67,5 \\
\hline 08/98 & 69 & 0 & 0 & 13,0 & 26,4 & 12,1 & 66,7 \\
\hline 09/98 & 76 & 5,2 & 5 & 15,7 & 25,5 & 20,6 & 84,2 \\
\hline 09/98 & 83 & 0 & 0 & 15,6 & 30,0 & 22,8 & 72,7 \\
\hline $09 / 98$ & 92 & 4,0 & 3 & 14,6 & 28,0 & 21,3 & 71,4 \\
\hline & & $12,5^{2}$ & $15^{2}$ & $14,02^{3}$ & $27,3^{3}$ & $19,83^{3}$ & $76,74^{3}$ \\
\hline
\end{tabular}

${ }^{1}$ DAP: Dias após o plantio

${ }^{2}$ Somatória do período

${ }^{3}$ Média do período

Tabela 4. Dados climáticos realizados durante a execução do experimento do C2 (mancha angular - trifenil hidróxido de estanho). Piracicaba, São Paulo, $1998-2000$.

\begin{tabular}{cccccccc}
\hline Mês/ Ano & DAP $^{1}$ & \multicolumn{2}{c}{ Precipitação } & \multicolumn{3}{c}{ Temperatura $\left({ }^{\circ} \mathrm{C}\right)$} & UR \\
\cline { 3 - 6 } & & $\mathrm{mm}$ & $\begin{array}{c}\text { No. de } \\
\text { dias }\end{array}$ & Mínima & Máxima & Média & $\%$ \\
\hline $12 / 98$ & 27 & 0,9 & 3 & 17,1 & 30,9 & 23,9 & 74,2 \\
$12 / 98$ & 34 & 18,3 & 5 & 19,9 & 30,4 & 25,2 & 81,8 \\
$12 / 98$ & 41 & 11,1 & 6 & 20,5 & 29,8 & 25,2 & 87,7 \\
$12 / 98$ & 46 & 2,9 & 2 & 18,2 & 30,3 & 24,2 & 76,6 \\
$12 / 98$ & 53 & 10,1 & 4 & 18,2 & 27,1 & 22,6 & 90,8 \\
$01 / 99$ & 62 & 16,4 & 7 & 20,3 & 28,0 & 24,1 & 91,5 \\
$01 / 99$ & 69 & 11,6 & 5 & 20,0 & 30,1 & 25,1 & 88,5 \\
\hline & $71,3^{2}$ & $32^{2}$ & $19,17^{3}$ & $29,51^{3}$ & $24,32^{3}$ & $84,44^{3}$ \\
\hline
\end{tabular}

${ }^{1}$ DAP: Dias após o plantio

${ }^{2}$ Somatória do período

${ }^{3}$ Média do período 
Tabela 5. Dados climáticos realizados durante a execução do experimento do C3 (ferrugem - oxycarboxin). Piracicaba, São Paulo, 1998 - 2000.

\begin{tabular}{|c|c|c|c|c|c|c|c|}
\hline \multirow[t]{2}{*}{ Mês/ Ano } & \multirow[t]{2}{*}{$\mathrm{DAP}^{1}$} & \multicolumn{2}{|c|}{ Precipitação } & \multicolumn{3}{|c|}{ Temperatura $\left({ }^{\circ} \mathrm{C}\right)$} & \multirow{2}{*}{$\begin{array}{c}\text { UR } \\
\%\end{array}$} \\
\hline & & $\mathrm{mm}$ & $\begin{array}{c}\text { No. de } \\
\text { dias }\end{array}$ & Mínimas & Máxima & Média & \\
\hline $07 / 99$ & 38 & 1,73 & 8 & 11,46 & 24,35 & 17,92 & 81,77 \\
\hline 07/99 & 46 & 0,16 & 2 & 12,88 & 27,88 & 20,29 & 75,38 \\
\hline 07/99 & 52 & 0 & 0 & 12,50 & 29,18 & 20,87 & 71,33 \\
\hline 08/99 & 67 & 0 & 0 & 9,58 & 27,11 & 18,36 & 69,20 \\
\hline 08/99 & 73 & 0 & 0 & 8,65 & 23,10 & 15,90 & 69,50 \\
\hline 08/99 & 81 & 0 & 0 & 11,54 & 30,01 & 20,80 & 56,88 \\
\hline 08/99 & 88 & 0 & 0 & 12,87 & 33,30 & 23,11 & 52,0 \\
\hline 09/99 & 94 & 7,47 & 2 & 16,47 & 29,73 & 23,12 & 66,0 \\
\hline & & $9,36^{2}$ & $12^{2}$ & $11,99^{3}$ & $28,08^{3}$ & $20.05^{3}$ & $67,75^{3}$ \\
\hline
\end{tabular}

${ }^{1}$ DAP: Dias após o plantio

${ }^{2}$ Somatória do período

${ }^{3}$ Média do período

Tabela 6. Dados climáticos realizados durante a execução do experimento do C4. (mancha angular - trifenil hidróxido de estanho). Piracicaba, São Paulo, 1998 - 2000.

\begin{tabular}{|c|c|c|c|c|c|c|c|}
\hline \multirow[t]{2}{*}{ Mês/ Ano } & \multirow[t]{2}{*}{$\mathrm{DAP}^{1}$} & \multicolumn{2}{|c|}{ Precipitação } & \multicolumn{3}{|c|}{ Temperatura $\left({ }^{\circ} \mathrm{C}\right)$} & \multirow{2}{*}{$\begin{array}{c}\text { UR } \\
\%\end{array}$} \\
\hline & & $\mathrm{mm}$ & $\begin{array}{c}\text { No. de } \\
\text { dias }\end{array}$ & Mínima & Máxima & Média & \\
\hline $02 / 00$ & 31 & 4,4 & 14 & 19,2 & 30,7 & 25,0 & 81,4 \\
\hline $02 / 00$ & 39 & 6,9 & 5 & 19,2 & 27,7 & 23,4 & 90,8 \\
\hline $02 / 00$ & 44 & 0,9 & 2 & 17,6 & 31,0 & 24,3 & 83,0 \\
\hline $02 / 00$ & 52 & 5,3 & 4 & 19,2 & 32,3 & 25,8 & 85,4 \\
\hline $03 / 00$ & 60 & 2,9 & 1 & 18,5 & 29,9 & 24,2 & 83,0 \\
\hline 03/00 & 66 & 0,2 & 1 & 17,5 & 29,6 & 23,5 & 81,7 \\
\hline 03/00 & 73 & 3,6 & 4 & 19,8 & 29,4 & 24,6 & 84,9 \\
\hline $03 / 00$ & 78 & 23,3 & 3 & 19,0 & 30,0 & 24,5 & 85,8 \\
\hline $04 / 00$ & 85 & 0,1 & 1 & 17,3 & 28,0 & 22,6 & 82,3 \\
\hline & & $47,6^{2}$ & $35^{2}$ & $18,58^{3}$ & $29.84^{3}$ & $24,21^{2}$ & $84,25^{3}$ \\
\hline
\end{tabular}

${ }^{1}$ DAP: Dias após o plantio

${ }^{2}$ Somatória do período

${ }^{3}$ Média do período 
Durante a condução dos experimentos a radiação solar média do experimento $(\mathrm{C} 1)$ foi de 13,42 $\mathrm{MJ} \mathrm{m}^{-2}$ por dia; 17,33 $\mathrm{MJ} \mathrm{m}^{-2}$ por dia para o experimento $\mathrm{C} 2 ; 14,34 \mathrm{MJ} \mathrm{m}^{-2}$ por dia para o experimento $\mathrm{C} 3$ e $18,59 \mathrm{MJ} \mathrm{m}^{-2}$ por dia para o experimento $\mathrm{C} 4$.

4.3 Área Foliar, Área sob a Curva de Progresso da Doença (AUDPC), Duração da Área Foliar Sadia (HAD), Absorção da Área Foliar Sadia (HAA) e Produção

Conforme enunciado no item 3.2 (Avaliações do Desenvolvimento do Hospedeiro, Severidade da Doença e Produção), para evitar os possíveis danos nas plantas a serem avaliadas com o ceptômetro, cada parcela foi dividida em duas partes, sendo a primeira metade (1S) destinada às medições manuais da área foliar (cm) e porcentagem da severidade da doença e a segunda metade (2S) foi destinada às medições com o ceptômetro.

A seguir serão apresentados os dados obtidos da primeira metade da parcela (1S). Já no item 5.5 serão apresentados os dados obtidos da segunda metade da parcela $(2 \mathrm{~S})$

As avaliações da área foliar $(\mathrm{cm})$ dos experimentos foram iniciadas com o surgimento do primeiro par de folhas trifolioladas, estádio V3 da escala descrita por Michaelis (1994), aproximadamente aos 34, 38, 27 e 44 DAP, respectivamente para os experimentos $\mathrm{C} 1, \mathrm{C} 3, \mathrm{C} 2$ e $\mathrm{C} 4$.

Para os experimentos C1 e C3 (ferrugem - oxycarboxin), as avaliações da área foliar (cm) foram realizadas respectivamente aos 34, 41, 48, 55, 62, 69, 76, 83 e 92 dias após o plantio (DAP) e aos 38, 46, 52, 67, 73, 81, 88 e 94 DAP. Já para os experimentos C2 e C4 (mancha angular - trifenil hidróxido de estanho), as avaliações da área foliar (cm) foram realizadas, respectivamente aos 27, 34, 41, 46, 53, 62 e 69 DAP e aos 31, 39, 44, 52, 60, 66, 73, 78 e 85 DAP.

Na Tabela 7 estão representadas as datas de pulverizações com os fungicidas oxycarboxin e trifenil hidróxido de estanho aplicados nos experimentos $\mathrm{C} 1$, $\mathrm{C} 3$ e $\mathrm{C} 2$ e $\mathrm{C} 4$, respectivamente, em todos os tratamentos. 
Nota-se através da Figura 3, que o progresso da área foliar $(\mathrm{cm})$ do experimento $\mathrm{C} 1$ (média de 12 plantas por tratamento) teve seus incrementos crescentes até os 76 DAP para o tratamento T1 e até os 69 DAP para o tratamento T5. Já no experimento $\mathrm{C} 2$ para ambos os tratamentos (T1 e T5) o progresso da área foliar $(\mathrm{cm})$ atingiu seu limite máximo aos 46 DAP. No experimento C3 os maiores valores da área foliar (cm) foram obtidos aos 80 DAP (T1) e aos 73 DAP (T5). Cinquienta e dois dias após o plantio e 60 DAP foram os períodos de maiores valores da área foliar $(\mathrm{cm})$ obtidos do experimento C4 nos tratamentos T1 e T5, respectivamente. Diante destes resultados, observa-se que nem sempre o tratamento $\mathrm{T} 5$, que recebia pulverizações semanais com os respectivos fungicidas para cada doença e que não recebeu nenhuma inoculação artificial, produziu maiores áreas foliares (experimentos C3 e C4) (Figura3).

O progresso da doença foi estimado através da área sob a curva de progresso da doença (AUDPC) (Vanderplank, 1963). Pode-se notar que em todos os experimentos $(\mathrm{C} 1, \mathrm{C} 2, \mathrm{C} 3$ e $\mathrm{C} 4)$ houve uma distribuição contínua entre os valores da $A U D P C$, ou seja, as plantas apresentaram diferentes áreas sob a curva de progresso da doença, condições estas necessárias para o estabelecimento de uma função de dano (Figura 4). Estes diferentes valores da $A U D P C$ foram obtidos graças as diferentes épocas de aplicação dos fungicidas para o controle da ferrugem e da mancha angular do feijoeiro, proporcionando assim diferentes variações na severidade das doenças (Tabela 2). 

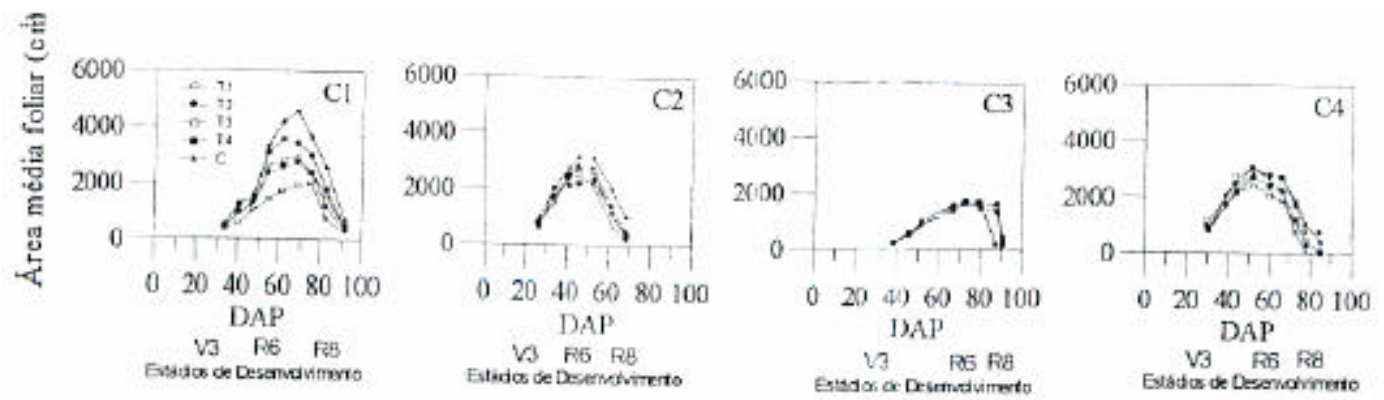

Figura 3 - Valores médios da área foliar $(\mathrm{cm})$ dos experimentos $\mathrm{C} 1$ e $\mathrm{C} 3$ (ferrugem oxycarboxin) e dos experimentos C2 e C4 (mancha angular - trifenil hidróxido de estanho) do feijoeiro. Piracicaba, São Paulo, 1998 - 2000.

Tabela 7. Época de pulverização dos experimentos C1, C3 (ferrugem), C2 e C4 (mancha angular) com os fungicidas oxycarboxin e trifenil hidróxido de estanho, respectivamente. Piracicaba. São Paulo, 1998 - 2000.

\begin{tabular}{ccccc}
\hline Tratamentos & $\begin{array}{c}\text { Experimento C1 } \\
\left(\mathrm{DAP}^{1}\right)\end{array}$ & $\begin{array}{c}\text { Experimento C2 } \\
\left(\mathrm{DAP}^{1}\right)\end{array}$ & $\begin{array}{c}\text { Experimento C3 } \\
\left(\mathrm{DAP}^{1}\right)\end{array}$ & $\begin{array}{c}\text { Experimento C4 } \\
\left(\mathrm{DAP}^{1}\right)\end{array}$ \\
\hline T1 & - & - & - & - \\
T2 & 48,62 & 34,48 & 59,73 & 38,52 \\
T3 & 62,76 & 48,62 & 73,88 & 52,68 \\
T4 & $48,62,76$ & $34,48,62$ & $59,73,88$ & $38,52,66$ \\
T5 & $34,41,48,55,62$, & $27,34,41,48$, & $45,52,59,66$, & $31,38,45,52$, \\
& $69,76,83,90$ & $55,62,69$ & $84,87,94$ & $60,67,74$ \\
\hline
\end{tabular}

${ }^{1}$ DAP: Dias após o plantio 

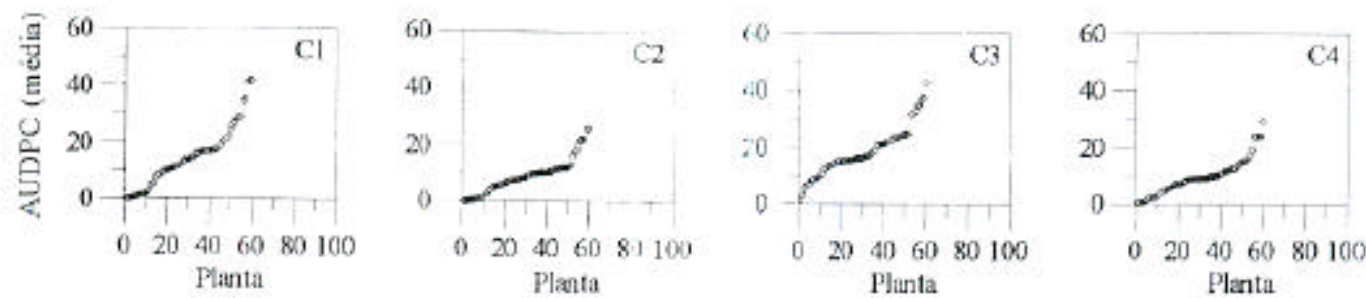

Figura 4 - Valores individuais da área sob a curva de progresso da doença (AUDPC) (60 plantas) promovida pela ferrugem (experimentos C1 e C3) e pela mancha angular (experimentos C2 e C4) do feijoeiro. Piracicaba, São Paulo, 1998 - 2000.

A proposta inicial na condução dos experimentos era que um dos tratamentos fosse totalmente livre de doença (T5), de forma a simular uma situação de produção sensu Lopes et al. (1994), entretanto pode-se notar na Figura 5 que o tratamento $\mathrm{T} 5$, nos experimentos $\mathrm{C} 1$ e C3, já na primeira avaliação, apresentava porcentagens de severidade da ferrugem, continuando seu progresso em baixos níveis no decorrer dos experimentos mesmo aplicando-se semanalmente o fungicida oxycarboxin. O motivo para tal evento pode ser explicado pela presença de inoculo inicial presente na área dos experimentos, além da pressão de inóculo exercida pelos demais tratamentos (T1, T2, T3 e T4) que receberam duas inoculações artificiais com urediniósporos do fungo.

No experimento C1 (ferrugem - oxycarboxin), os maiores valores de $A U D P C$ foram obtidos no tratamento T2 (19,17 unidades de $A U D P C)$ apesar dos demais tratamentos (T1, T3 e T4) não terem diferido ao nível de 5\% de probabilidade ao Teste de Tukey (15,2; 15,4 e 16,5 unidades de AUDPC, respectivamente). O tratamento T5 apresentou 4,4 unidades de AUDPC. Já no experimento C3 (ferrugem - 
oxycarboxin), os maiores valores de $A U D P C$ foram obtidos no tratamento T3 $(24,21$ unidades de $A U D P C$ ), sendo este tratamento estatisticamente semelhante ao tratamento T1 e T4 (21,17 e 18,26 unidades de $A U D P C$, respectivamente). Os tratamentos T2 e T5 foram estatisticamente semelhantes (16,39 e 11,78 unidades de AUDPC) (Figura 6).

Com relação ao experimento C2 (mancha angular - trifenil hidróxido de estanho), os maiores valores de $A U D P C$ foram obtidos pelo tratamento T1 $(13,97$ unidades de $A U D P C)$, sendo este estatisticamente semelhante ao tratamento T3 $(10,42$ unidades de $A U D P C$ ). Os tratamentos $\mathrm{T} 2$ e T4 foram estatisticamente semelhantes e apresentaram 7,6 e 9,9 unidades de $A U D P C$, respectivamente. Já no experimento C4 (mancha angular - trifenil hidróxido de estanho) os maiores valores de AUDPC foram obtidos pelo tratamento T1 (15,29 unidades de $A U D P C)$, sendo os tratamento T2 e T4 os que apresentaram valores de $A U D P C$ intermediários. Neste experimento o tratamento T5 apresentou apenas 1,51 unidades de AUDPC (Figura 6).

Segundo Cardona-Alvarez \& Walker (1956) e Saettler (1991), os sintomas da mancha angular do feijoeiro no campo são geralmente observados logo após a floração ou em plantas próximas a maturidade, fato este também comprovado nos experimentos $\mathrm{C} 2$ e $\mathrm{C} 4$, onde os maiores valores de $A U D P C$ foram encontrados nos tratamento T3, isto é entre os 48 e 62 DAP para o experimento C2 e entre os 52 e 68 DAP para o experimento C4 (Figura 6). 

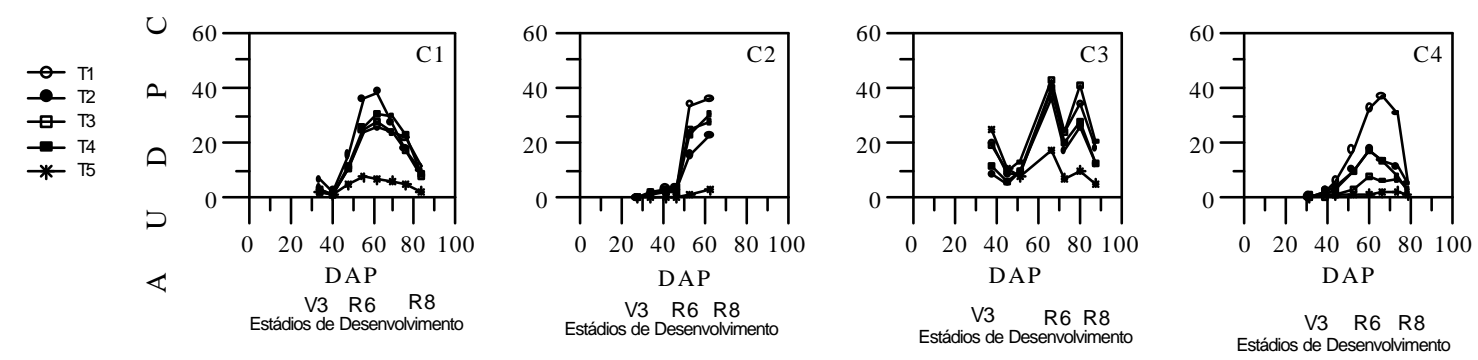

Figura 5 - Área sob a curva de progresso da doença (AUDPC) promovida pela ferrugem (experimentos $\mathrm{C} 1$ e C3) e mancha angular (experimentos $\mathrm{C} 2$ e C4) do feijoeiro. Valores médios de 12 plantas por tratamento. Piracicaba, São Paulo, 1998 - 2000.

Os dados dos componentes da produção número de vagens viáveis por planta, número de sementes viáveis e peso das sementes (gramas/planta) (média \pm desvio padrão de 12 plantas por tratamento) dos experimentos C1, C2, C3 e C4 estão representados na Tabela 8 entretanto serão apresentados graficamente apenas o componente da produção gramas por planta (média \pm desvio padrão de 12 plantas por tratamento) relacionado com as variáveis AUDPC, HAD, HAA, HLAI, HRI e porcentagem de desfolha. 

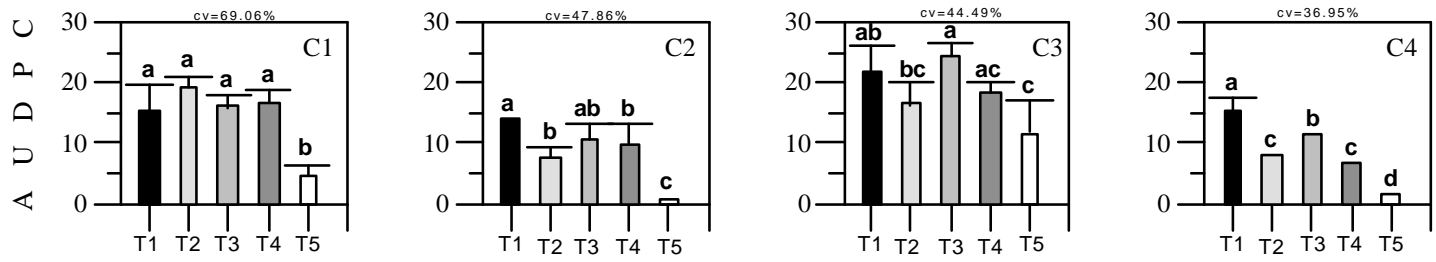

Figura 6 - Área sob a curva de progresso da doença (AUDPC) promovida pela ferrugem (experimentos C1 e C3) e mancha angular (experimentos C2 e C4) do feijoeiro. Valores médios de 12 plantas por tratamento.

Médias seguidas de mesma letra não diferem significativamente entre si pelo teste de Tukey (p<0,05). Piracicaba, São Paulo, 1998 - 2000.

A produção em gramas por planta dos experimentos $\mathrm{C} 1, \mathrm{C} 2, \mathrm{C} 3$ e $\mathrm{C} 4$ estão representados na Tabela 8 e Figura 7.

Observando os dados de peso de sementes/planta (gramas) nota-se que o tratamento T5 apresentou maiores valores de produção nos experimentos C1, C2 e C3. No experimento C1 (ferrugem - oxycarboxin) os tratamentos T1, T2 e T4 foram estatisticamente semelhantes ao tratamento T5, apresentando os tratamentos T4, T1 e T3 como intermediários. No experimento C2 (mancha angular - trifenil hidróxido de estanho) o tratamento T4 foi estatisticamente semelhante ao T5, ficando os tratamentos T3 e T2 com intermediários. A aplicação com o fungicida trifenil hidróxido de estanho antes ou após a floração não promoveu diferença na produtividade. $\mathrm{O}$ experimento $\mathrm{C} 3$ não apresentou diferença estatística entre os tratamentos (Tukey $p<0,05$ ), evidenciando que as diferentes épocas de aplicação do fungicida oxycarboxin não trouxeram nenhum ganho na produção, quando comparados ao tratamento T1 (s/ pulverização com fungicidas e com duas inoculações artificiais em intervalo de 10 dias). No experimento C4 (mancha angular - trifenil hidróxido de estanho) o tratamento T5 foi o 
que apresentou maior produção por planta ficando o tratamento T2 como intermediário e os tratamentos T1, T4 e T3 como inferiores.

A aplicação dos fungicidas oxycarboxin e trifenil hidróxido de estanho em diferentes épocas proporcionou diferença na produtividade dos tratamentos dos experimentos com a ferrugem e mancha angular do feijoeiro. Na Figura 8 estão os dados da produção gramas/parcela (média \pm desvio padrão de três parcelas) dos experimentos $\mathrm{C} 1, \mathrm{C} 2, \mathrm{C} 3$ e $\mathrm{C} 4$.

Observa-se que o tratamento T5 apresentou maior produção (gramas) em todos os experimentos $(822,35 \pm 209,05$ para $\mathrm{C} 1 ; 681,99 \pm 101,80$ para $\mathrm{C} 2 ; 905,42$ $\pm 201,0$ para C3 e 859,11 $\pm 25,28$ para C4). No experimento $\mathrm{C} 1$, os tratamentos $\mathrm{T} 2$ e T4 apresentaram produção estatisticamente semelhante ao tratamento T5, isto é 770,30 \pm 144,37 e 589, $67 \pm$ 159,31 gramas, ficando o tratamento T3 com a menor produtividade $(513,17 \pm 96,61)$. Já no experimento C2 o tratamento T3 foi o que apresentou a produtividade semelhante ao tratamento T5 $(625,48 \pm 87,22$ gramas $)$, ficando os tratamentos T2 e T4 como intermediários $(473,13 \pm 90,06$ e 522,6 \pm 46,19 gramas). As diferentes épocas de aplicação com os fungicidas não proporcionaram diferenças estatísticas (Tukey $\mathrm{p}<0,05$ ) na produtividade do experimento C3. Já no experimento $\mathrm{C} 4$ o tratamento $\mathrm{T} 4$ foi o que apresentou semelhança estatística com o tratamento T5 $(691,86 \pm 113,36)$, ficando os tratamentos T2 e T3 com produtividade intermediária $(601,67 \pm 81,35$ e 591,36 \pm 151,14 gramas, respectivamente). 
Tabela 8. Dados dos componentes da produção número de vagens viáveis, no. de sementes viáveis e peso sementes (gramas) obtidos do experimento $\mathrm{C} 1$, C2, C3 e C4. Piracicaba, São Paulo. 1998 - 2000.

\begin{tabular}{|c|c|c|c|}
\hline $\mathrm{C} 1$ & No.vagens viáveis $^{2}$ & No.de sementes viáveis $^{2}$ & $\begin{array}{c}\text { Peso sementes } \\
\text { (gramas) }^{1-2}\end{array}$ \\
\hline $\mathrm{T} 1$ & $9,50 \pm 5,28$ & $71,58 \pm 34,36$ & $13,97 \pm 6,15 \mathrm{ab}$ \\
\hline $\mathrm{T} 2$ & $13,41 \pm 8,68$ & $68,16 \pm 48,63$ & $11,81 \pm 9,24 \mathrm{a}$ \\
\hline $\mathrm{T} 3$ & $15,36 \pm 8,50$ & $74,63 \pm 45,76$ & $13,70 \pm 8,38 \mathrm{ab}$ \\
\hline $\mathrm{T} 4$ & $15,83 \pm 6,76$ & $80,25 \pm 35,52$ & $16,14 \pm 7,62 \mathrm{ab}$ \\
\hline T5 & $18,33 \pm 7,08$ & $119,0 \pm 41,90$ & $23,50 \pm 9,66 b$ \\
\hline $\mathrm{C} 2$ & No.vagens viáveis ${ }^{2}$ & Node sementes viáveis ${ }^{2}$ & $\begin{array}{c}\text { Peso sementes } \\
\text { (gramas) }^{1-2}\end{array}$ \\
\hline $\mathrm{T} 1$ & $7,45 \pm 4,24$ & $39,45 \pm 19,97$ & $4,82 \pm 2,58 \mathrm{a}$ \\
\hline $\mathrm{T} 2$ & $11,41 \pm 5,40$ & $51,83 \pm 24,86$ & $7,70 \pm 3,98 \mathrm{ab}$ \\
\hline $\mathrm{T} 3$ & $11,83 \pm 5,77$ & $56,26 \pm 29,56$ & $8,74 \pm 5,32 a b$ \\
\hline $\mathrm{T} 4$ & $15,08 \pm 8,46$ & $67,16 \pm 38,12$ & $10,65 \pm 6,52 b$ \\
\hline T5 & $17,81 \pm 8,97$ & $77,27 \pm 36,42$ & $12,32 \pm 6,76 b$ \\
\hline $\mathrm{C} 3$ & No.vagens viáveis $^{2}$ & No.de sementes viáveis ${ }^{2}$ & $\begin{array}{l}\text { Peso sementes } \\
\text { (gramas) }^{1-2}\end{array}$ \\
\hline $\mathrm{T} 1$ & $10,66 \pm 5,28$ & $53,25 \pm 28,05$ & $7,57 \pm 4,22 \mathrm{a}$ \\
\hline $\mathrm{T} 2$ & $11,41 \pm 4,10$ & $66,33 \pm 22,34$ & $8,27 \pm 4,02 \mathrm{a}$ \\
\hline $\mathrm{T} 3$ & $10,91 \pm 3,62$ & $64,25 \pm 16,67$ & $8,05 \pm 4,80 \mathrm{a}$ \\
\hline $\mathrm{T} 4$ & $12,16 \pm 4,21$ & $66,91 \pm 29,56$ & $7,85 \pm 4,75 \mathrm{a}$ \\
\hline T5 & $13,58 \pm 4,50$ & $72,91 \pm 19,57$ & $8,15 \pm 2,94 \mathrm{a}$ \\
\hline $\mathrm{C} 4$ & No.vagens viáveis ${ }^{2}$ & No.de sementes viáveis ${ }^{2}$ & $\begin{array}{l}\text { Peso sementes } \\
\text { (gramas) }^{1-2}\end{array}$ \\
\hline $\mathrm{T} 1$ & $19,09 \pm 10,18$ & $81,82 \pm 53,64$ & $17,68 \pm 10,57 \mathrm{a}$ \\
\hline $\mathrm{T} 2$ & $21,92 \pm 5,37$ & $102,92 \pm 32,87$ & $20,19 \pm 5,46 a b$ \\
\hline $\mathrm{T} 3$ & $14,83 \pm 7,91$ & $69,08 \pm 45,51$ & $14,17 \pm 8,96 a$ \\
\hline $\mathrm{T} 4$ & $18,26 \pm 7,34$ & $91,33 \pm 51,01$ & $17,06 \pm 8,85 \mathrm{a}$ \\
\hline $\mathrm{T} 5$ & $22,40 \pm 9,07$ & $122,50 \pm 70,65$ & $24,81 \pm 11,40 b$ \\
\hline
\end{tabular}

${ }^{1-2} \mathrm{Cv}=(35,78 \%$ para $\mathrm{C} 1 ; 33,17 \%$ para $\mathrm{C} 2 ; 29,57 \%$ para $\mathrm{C} 3$ e $32,64 \%$ para $\mathrm{C} 4)$.

${ }^{2}$ Média de 12 plantas por tratamento.

Médias seguidas de mesma letra não diferem significativamente entre si pelo teste de Tukey (p<0,05). Piracicaba, São Paulo, 1998 - 2000. 

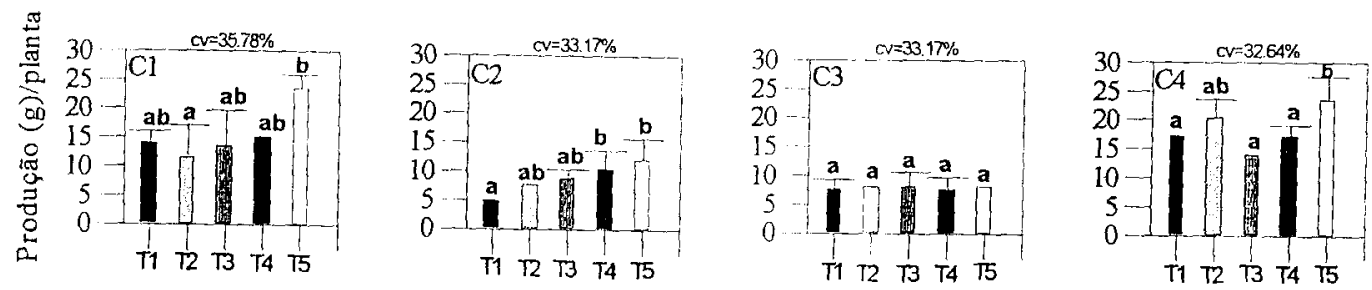

Figura 7 - Produção gramas por planta dos experimentos C1, C3 (ferrugem - oxycarboxin), C2 e C4 (mancha angular - trifenil hidróxido de estanho) do feijoeiro. Médias \pm desvio padrão de 12 plantas por tratamento.

Médias seguidas de mesma letra não diferem significativamente entre si pelo teste de Tukey $(p<0,05)$. Piracicaba, São Paulo, $1998-2000$.
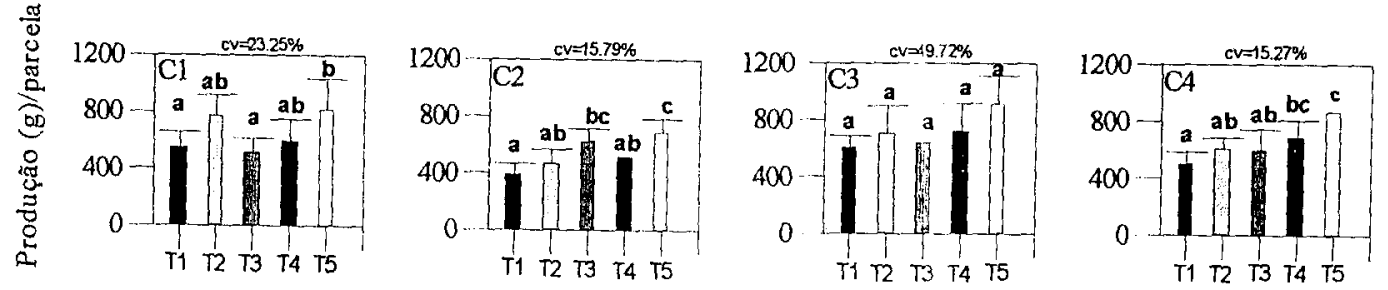

Figura 8 - Produção gramas por parcela dos experimentos C1, C3 (ferrugem oxycarboxin), C2 e C4 (mancha angular - trifenil hidróxido de estanho) do feijoeiro. Média \pm desvio padrão de três parcelas por tratamento.

Média seguidas de mesma letra não diferem significativamente entre si pelo teste de Tukey (p<0,05). Piracicaba, São Paulo, 1998 - 2000. 
Para verificar a possibilidade de correlação, a variável integral área sob a curva de progresso da doença $(A U D P C)$ foi relacionada com a produção gramas/planta (Figura 9). Constatou-se que apenas um dos quatro experimentos realizados (C4) apresentou relação entre estas variáveis. A relação encontrada foi a linear com coeficiente de determinação $\left(\mathrm{R}^{2}\right)$ de 0,11 (Produção=23,80148$0,59441 * A U D P C)$, relação esta considerada insatisfatória para prever danos quando comparada com as relações realizadas com $H A D$ (dias) e $H A A\left(\mathrm{MJ} \mathrm{m}^{-2}\right)$ e produção (Figuras 12 e 13). Neste experimento foi observada também uma maior porcentagem de desfolha $(45,30 \%)$ quando comparada aos demais experimentos (Figura 17). A maior queda das folhas pode ter contribuído para a obtenção de melhores ajustes entre a severidade e a produção.

Carneiro (1995) e Godoy (1995) não encontraram correlação entre estas variáveis no patossistema mancha angular - feijão. Lindgren et al. (1995), trabalhando com a ferrugem do feijoeiro, obtiveram ajuste linear entre dano e severidade da doença.

Silva et al. (1998) encontraram três ajustes exponenciais e um linear entre $A U D P C$ e produção quando estudaram os patossistemas antracnose, ferrugem e mancha angular do feijoeiro. Os coeficientes de determinação $\left(R^{2}\right)$ variaram de 0,10 a 0,37 em quatro das dez tentativas de correlação. Segundo estes autores, o fato de encontrar diferentes modelos que se ajustam a essa função de maneira satisfatória não é anormal, até mesmo quando se considera um único plantio e uma única doença como observado com a ferrugem em feijão - fava (Sache \& Zadoks, 1994).

Canteri (1998) encontrou relação linear negativa $(\mathrm{p}<0,01)$ com a produção $\left(\mathrm{g} \mathrm{m}^{-2}\right)$ no patossistema mancha angular - feijão, sugerindo que a ocorrência da relação entre estas variáveis está associada à quantidade máxima da área foliar sadia observada, fato este também notado por Bergamin Filho et al., (1997). Canteri (1998) sugere ainda que uma possível explicação para a ocorrência de relação entre a produção e a $A U D P C$ deve-se aos altos valores de $H L A I$ encontrados nas plantas, que as impede de provocar desfolha, desta forma, quando a desfolha é reduzida, a produção se relaciona com a severidade da doença. 
Com relação aos experimentos C1 e C3 (ferrugem - oxycarboxin), nenhum dos dois experimentos apresentaram relação entre as variáveis $A U D P C$ e produção (gramas por planta) (Figura 9), fato este também observado por Iamauti (1995) e Silva et al., (1998), quando estudaram este mesmo patossistema.

Em outros patossistemas os autores Pataky et al., (1983), Larsson \& Gerhardson (1992), Bissonnette et al., (1994), Griffey et al. (1994), Bryson et al., (1995), Gianasi (1999) e Diaz (2000) encontraram relações entre estas variáveis. A ausência de relação entre a produção e $A U D P C$ é mais comum quando dados de diferentes locais ou estações são comparados (Gaunt, 1995a; Gaunt \& Bryson, 1995).

O fato de haver mais do que um modelo que se ajuste aos dados de $A U D P C$ observados reflete a incerteza da relação entre essas duas variáveis bem como a falta de uma base fisiológica que explique a interdependência entre as mesmas.

Altos valores de AUDPC dos quatro experimentos (Figura 6) produziram também elevados valores de produção (Tabela 8 e Figura 7), uma contradição que já vem sendo discutida há algum tempo (Waggoner \& Berger, 1987; Aquino et al., 1988; Bergamin Filho et al., 1997).

A justificativa para a falta de relação entre as variáveis $A U D P C$ e produção foi enunciada por Waggoner \& Berger (1987). Estes autores sugeriram que a lógica da relação entre a severidade da doença e produção é incerta em virtude da severidade das doenças não fornecer estimativas a respeito do tamanho e da duração da área foliar da planta e da insolação absorvida por esta área foliar. Desta forma, plantas com a mesma porcentagem de severidade, mas com diferentes valores da área foliar podem apresentar potenciais distintos de produção.

Carneiro (1995) sugeriu que a falta de correlação entre estas variáveis é possível devido a fatores como a variação da área foliar doente durante o ciclo da cultura e a tolerância a maiores intensidades de doença em plantas com maiores áreas foliares.

Segundo Bergamin Filho et al. (1997), a falta de relação entre AUDPC e produção é atribuída a três fatores principais: $i$ ) intensa desfolha promovida pelo 
patógeno; ii) falta de estimativa de desfolha; iii) ao hábito de crescimento indeterminado do hospedeiro.

Modelos baseados na área foliar doente podem ter sucesso somente quando a área foliar é a mesma nos diferentes tratamentos que estão sendo comparados. A mesma proporção de severidade da doença nas diferentes áreas foliares pode não ter o mesmo impacto na produção. Segundo Bergamin Filho et al. (1997), isto se torna especialmente verdadeiro em patossistemas que causam desfolha e em hospedeiros com crescimento indeterminado. Este é caso dos experimentos C2 e C4 (mancha angular - trifenil hidróxido de estanho).
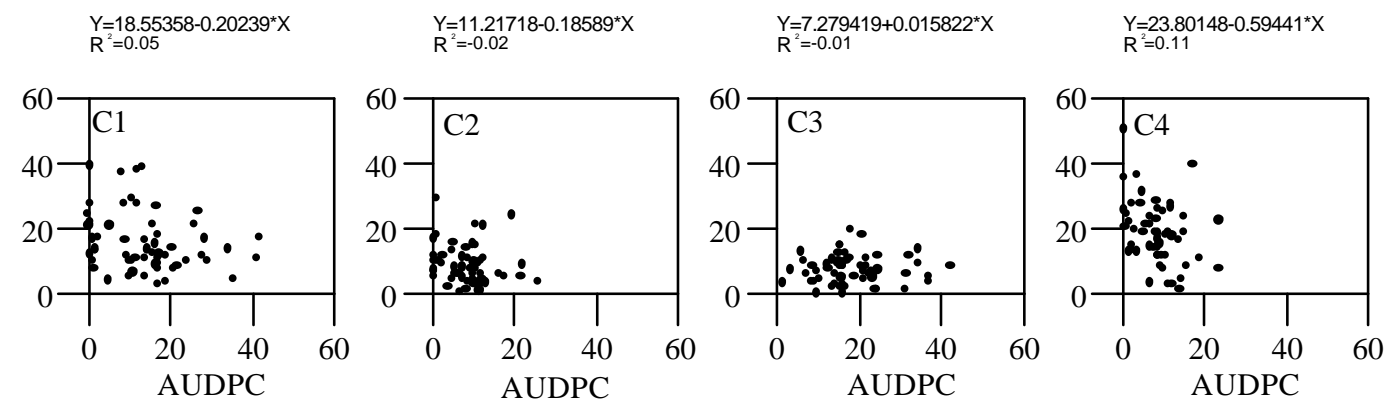

Figura 9 - Relação entre $A U D P C$ e produção (gramas por planta) de 60 plantas dos experimentos C1, C3 (ferrugem - oxycarboxin), C2 e C4 (mancha angular trifenil hidróxido de estanho) do feijoeiro. Piracicaba, São Paulo, 1998 2000 .

$\mathrm{Na}$ Figura 10 estão representados os valores de $H A D$ (dias) obtidos através da média de 12 plantas por tratamento dos experimentos $\mathrm{C} 1, \mathrm{C} 2, \mathrm{C} 3$ e $\mathrm{C} 4$ realizados entre o período de 1998 a 2000.

Os maiores valores de $H A D$ (dias) do experimento $\mathrm{C} 1$ foram encontrados na parcela controle (T5) (376 unidades de $H A D$ - dias). Neste experimento 
os valores de $H A D$ (dias) dos tratamentos $\mathrm{T} 4 \mathrm{e} \mathrm{T} 1$ foram estatisticamente semelhantes ao tratamento T5. Os menores valores de $H A D$ (dias) foram obtidos no experimento T2 (265 unidades de $H A D$ - dias). No experimento C2, o tratamento T5 foi o que apresentou maior valor de $H A D$ (dias), não diferindo estatisticamente dos tratamentos T2 e T3. Os experimentos C3 e C4 não apresentaram diferença estatística entre os valores de $H A D$ (dias) nos diferentes tratamentos realizados. Esses resultados advêm da semelhança entre os valores de HLAI observados (Figura 16).

Com relação aos valores da absorção da área foliar sadia (HAA - MJ m 2) do experimento $\mathrm{C} 1$, o tratamento $\mathrm{T} 5$ foi estatisticamente superior aos demais tratamentos, ficando como intermediários os tratamentos T4, T1 e T3, com valores respectivos de $H A A\left(\mathrm{MJ} \mathrm{m}^{-2}\right)$ de $850 ; 830$ e 822 unidades. O tratamento T2 apresentou o menor valor em unidades de $H A A\left(\mathrm{MJ} \mathrm{m}^{-2}\right)$. De igual forma aos valores de $H A D$ (dias), o experimento $\mathrm{C} 2$, apresentou no tratamento $\mathrm{T} 5$ valor estatisticamente superior aos demais experimentos (971,30 unidades de $H A A-\mathrm{MJ} \mathrm{m}^{-2}$ ), ficando os tratamentos T2 e T4 como intermediários (907,94 e 907,36 unidades de $H A A-\mathrm{MJm}^{-2}$ ) e os tratamentos T1 e T4 como inferiores $(854,46$ e 847,25) quando comparados ao T5 (Figura 11).

Não houve diferença estatística entre os tratamentos dos experimentos $\mathrm{C} 3$ e $\mathrm{C} 4$, isto em virtude dos valores de $H R I\left(\mathrm{MJ} \mathrm{m}^{-2}\right)$ também não terem apresentado diferença estatística previamente.

A ausência de diferença estatística entre os tratamentos dos experimentos $\mathrm{C} 3$ e $\mathrm{C} 4$, quando analisados os valores de $H A D$ (dias) e $H A A\left(\mathrm{MJ} \mathrm{\textrm {m } ^ { - 2 }}\right)$, mesmo quando a $A U D P C$ foi de 7 unidades, é, segundo Canteri (1998), devido às variações das condições edafo - climáticas nas áreas dos experimentos e também devido a redução da eficiência fotossintética na área foliar remanescente nas plantas.

Comparando-se os dados de $H A A\left(\mathrm{MJ} \mathrm{m}^{-2}\right)$ dos quatro experimentos, observa-se que os experimentos C2 e C4 foram o que apresentaram maiores valores de $H A A\left(\mathrm{MJ} \mathrm{m}^{-2}\right)$, correspondendo aos altos valores de radiação solar média do período (17,33 $\mathrm{MJ} \mathrm{m}^{-2}$ por dia e $18,59 \mathrm{MJ} \mathrm{m}^{-2}$ por dia, respectivamente). 
Diante dos resultados de relação insatisfatórios entre $A U D P C$ e produção (gramas/planta), procurou-se encontrar uma relação funcional entre a produção (gramas/planta) e as variáveis Duração da Área Foliar Sadia (HAD) e Absorção da Área Foliar Sadia (HAA).

As Figuras 12 e 13 trazem a relação entre $H A D$ (dias) e $H A A\left(\mathrm{MJ} \mathrm{m}^{-2}\right)$ produção (gramas/planta) para os experimentos $\mathrm{C} 1, \mathrm{C} 2, \mathrm{C} 3$ e C4. Foram realizadas, entre as variáveis, regressões lineares com passagem forçada pela origem e também regressões exponenciais em todos os experimentos de modo a verificar, através dos coeficientes de determinação $\left(\mathrm{R}^{2}\right)$ e distribuição normal dos resíduos, qual o melhor ajuste para estes dados.
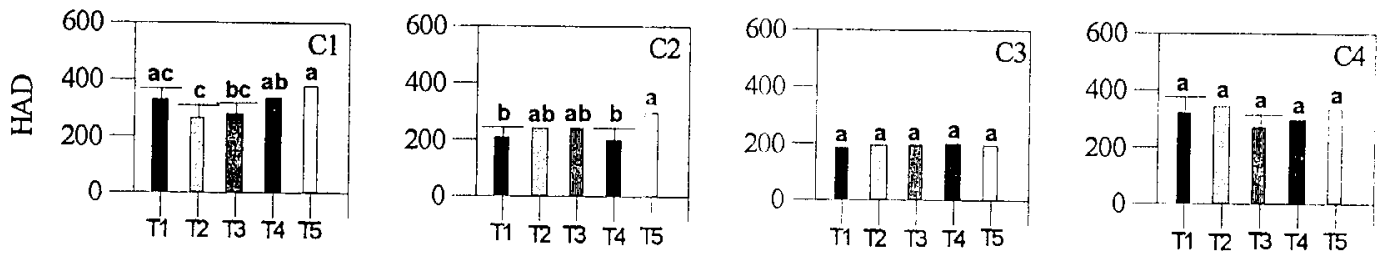

Figura 10 - Médias \pm desvio padrão de 12 plantas por tratamento de $H A D$ (dias) dos experimentos $\mathrm{C} 1, \mathrm{C} 3$ (ferrugem - oxycarboxin), $\mathrm{C} 2$ e $\mathrm{C} 4$ (mancha angular trifenil hidróxido de estanho) do feijoeiro. Médias seguidas de mesma letra não diferem significativamente entre si pelo teste de Tukey $(p<0,05)$. Piracicaba, São Paulo, 1998 - 2000. 

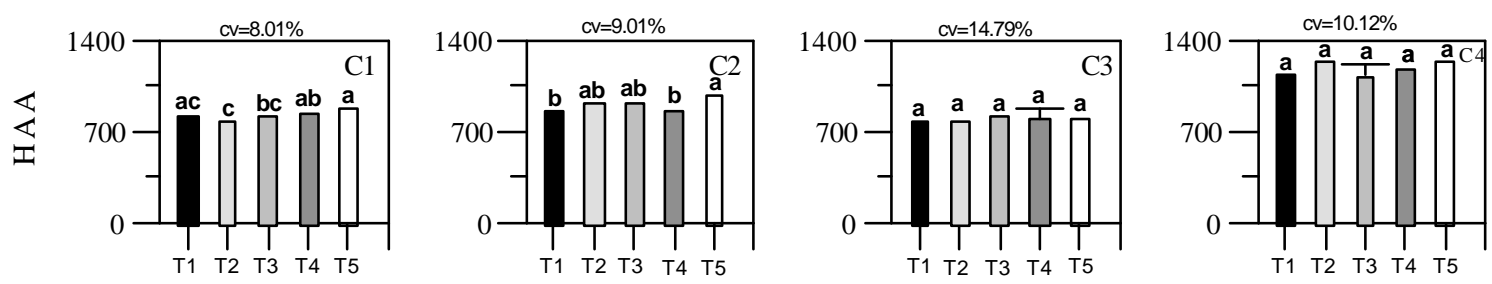

Figura 11 - Médias \pm desvio padrão de 12 plantas por tratamento de $H A A\left(\mathrm{MJ} \mathrm{m}^{-2}\right)$ dos experimentos C1, C3 (ferrugem - oxycarboxin), C2 e C4 (mancha angular trifenil hidróxido de estanho) do feijoeiro. Médias seguidas de mesma letra não diferem significativamente entre si pelo teste de Tukey $(\mathrm{p}<0,05)$. Piracicaba, São Paulo, 1998 - 2000.

A tendência dos pontos apresentados na relação $H A D$ (dias) e produção (gramas/planta) nos experimentos C1 (ferrugem - oxycarboxin) e C4 (mancha angular - trifenil hidróxido de estanho) foi exponencial, com valores respectivos de $\mathrm{R}^{2}=0,56$ (equação: $\quad$ Produção=3,479*exp $(0,004 * H A D)$ ) e $\quad \mathrm{R}^{2}=0,56 \quad$ (equação: Produção=2,9311*exp $\left(0,005^{*} H A D\right)$ ). Já para os experimentos C2 (mancha angular trifenil hidróxido de estanho) e C3 (ferrugem - oxycarboxin) as tendências foram lineares com coeficientes de determinação de 0,19 e 0,30. As equações propostas foram: Produção=0,0417079*HAD e Produção=0,0387556*HAD, respectivamente. Essa linearidade encontrada para a variável $H A D$ (dias) foi explicada por Silva et al. (1998) pelo hábito de crescimento semi-indeterminado do hospedeiro. Nestes experimentos a produção aumentou linearmente e não assintoticamente com o aumento da área foliar $(H L A I>4)$.

Os coeficientes de determinação encontrados nestes experimentos não foram tão elevados como aqueles obtidos por Carneiro (1995); Godoy (1995), Iamauti 
(1995), Nunes \& Bergamin Filho (1996); Bergamin Filho et al., (1997), Canteri et al. (1998); Carneiro et al. (2000), Gianasi (1999), Diaz (2000), mas são válidos principalmente por se tratar de ensaios de campo utilizando-se de plantas individuais (Madden, 1983).

Silva et al. (1998), estudando os patossistemas mancha angular, ferrugem e antracnose do feijoeiro, encontraram tendências lineares nos pontos entre $H A D$ (dias) e produção em nove experimentos. Apenas um apresentou tendência exponencial. Bergamin Filho et al. (1997) encontraram em todos os cinco experimentos analisados relação linear entre $H A D$ (dias) e produção. Ferrandino \& Elmer (1992) observaram que o maior efeito da doença sobre a produção foi na redução do $H A D$.

Essa linearidade encontrada nos experimentos contrasta com a relação não-linear (curva de Gompertz) proposta originalmente por Waggoner \& Berger (1987) para o patossistema Cercosporidium personatum - amendoim. Waggoner \& Berger (1987) realizaram análises de dados com os resultados de outros pesquisadores como Greene \& Gorbet (1973); Nickle (1977); Mangold (1979); Wilkerson et al., (1984); Pixley (1985), que trabalharam com amendoim desfolhado manualmente ou por doenças. Estes autores demonstraram alta correlação entre $H A D$ (dias) e produção, função esta descrita pelo modelo de Gompertz. Aquino et al. (1992) também encontraram relação não-linear em seus estudos.

Rotem et al. (1983; 1983b) também evidenciaram relação linear entre $H A D$ (dias) e produção para o patossistema batata - Phytophthora infestans. Outros trabalhos mais antigos também encontraram tendências lineares, em diferentes patossistemas, na relação entre $H A D$ (dias) e produção. São eles: Griffith (1981); Daamen \& Jorristsma (1990); Rotem et al. (1983a); Wilkedon et al. (1984); Shaw \& Royle (1989); Subba Rao et al., (1989); Johnson \& Teng (1990), Spitters et al. (1990); Roermund \& Spitters (1990); Rossing et al. (1992); Lindegreen et al. (1995) e Paveley et al. (1997). 
As diferenças observadas entre os experimentos confirmam as observações de Bergamin Filho et al. (1997) de que diferentes situações de produção resultam em diferentes relações entre $H A D$ (dias) e produção.

Rotem et al. (1983) observaram que a mesma área sadia resultou em diferentes produções dependendo da safra. Assim, os autores concluíram que avaliações de dano não podem ser separadas de avaliações do potencial de produção da cultura devido ao efeito de fatores edáficos e climáticos. Já Griffiths (1984) obteve uma ótima correlação entre $H A D$ (dias) e produção. $\mathrm{O}$ autor também concluiu que os fatores ambientais influenciaram a relação $H A D$ (dias) e produção.

Observando agora a Figura 13, que traz as relações entre a absorção da área foliar sadia - HAA $\left(\mathrm{MJ} \mathrm{m}^{-2}\right)$ e produção (gramas/planta), nota-se que dos quatro experimentos realizados apenas um (C3) apresentou tendência linear, quando foi realizada regressão com passagem forçada pela origem. Neste experimento, o coeficiente de determinação foi 0,23 (equação: Produção=0,009745*HAA).

Já os experimentos C1, C2 e C4 apresentaram tendências exponenciais com coeficientes de determinação relativamente altos. Para o experimento $\mathrm{C} 1$ a equação proposta foi: Produção $=0,158 * \exp (0,0053 * H A A)$, com $\mathrm{R}^{2}=0,44$. Já para o experimento C2 a equação proposta foi: Produção=0,0266*exp $(0,0062 * H A A)$, com $\mathrm{R}^{2}=0,55$ e para o experimento $\mathrm{C} 4$ a equação proposta foi: Produção=0,1419*exp $\left(0,0041^{*} H A A\right)$, com $\mathrm{R}^{2}=0,49$. Bergamin Filho et al. (1997) sugeriram que a função exponencial encontrada em experimentos como estes é devido aos elevados valores de HLAI obtidos, fato este também observado nestes experimentos (Figura 22).

Madeira et al. (1988) avaliaram as variáveis $H A D\left(\right.$ dias) e $H A A\left(\mathrm{MJ} \mathrm{m}^{2}\right)$ e encontraram relação linear entre estas variáveis e a produção de matéria seca com alto coeficiente de correlação.

Carneiro et al. (2000) encontraram relações lineares entre $H A A\left(\mathrm{MJ} \mathrm{m}^{2}\right)$ e produção $\left(\mathrm{g} / \mathrm{m}^{2}\right)$ no patossistema mancha angular e antracnose do feijoeiro. Os coeficientes de determinação apresentaram-se entre 0,59 e 0,85. Em alguns casos, a autora encontrou possíveis relações exponenciais nos ajustes dos dados, entretanto, a 
regressão linear foi preferida em virtude dos maiores coeficientes de determinação encontrados e também pela melhor distribuição dos resíduos.

Gianasi (1999) obteve em três dos quatro experimentos realizados, com o patossistema antracnose - feijão, relações lineares entre $H A A\left(\mathrm{MJ} \mathrm{m}^{-2}\right)$ e produção, com coeficientes de determinação variáveis entre 0,27 e 0,67. O modelo exponencial apresentou o melhor ajuste em apenas um dos experimentos $\left(\mathrm{R}^{2}=0,75\right)$.

Godoy (1995) e Iamauti (1995), estudando os patossistemas mancha angular e ferrugem do feijoeiro, respectivamente, também encontraram relações exponenciais entre estas variáveis. Este fato foi sugerido por Silva (1997) como devido as relações fonte dreno presente na cultura do feijoeiro. De igual forma Diaz (2000) encontrou relações exponenciais na relação $H A A\left(\mathrm{MJ} \mathrm{m}^{-2}\right)$ e produção $\left(\mathrm{g} / \mathrm{m}^{2}\right)$ quando estudou o crestamento bacteriano comum no feijoeiro, com coeficientes de determinação variando de 0,51 a 0,82 .

A não linearidade entre $H A A\left(\mathrm{MJ} \mathrm{m}^{2}\right)$ e produção também pode ser encontrada em Hughes et al. (1981) em feijão guandu.

De modo geral pode-se dizer que os melhores ajustes para os dados da produção nos patossistemas ferrugem e mancha angular do feijoeiro foram obtidos com a variável $H A A\left(\mathrm{MJ} \mathrm{m}^{-2}\right)$, confirmando os dados encontrados por Nunes (1994), Carneiro (1995), Godoy (1995) e Iamauti (1995).

Silva et al. (1998) e Diaz (2000) obtiveram com HAD (dias) os melhores ajustes. Estes autores suportaram a idéia de que maiores considerações sobre a fisiologia da planta podem levar a melhores resultados entre as relações de $H A A(\mathrm{MJ}$ $\left.\mathrm{m}^{2}\right)$. O conceito de $H A A\left(\mathrm{MJ} \mathrm{m}^{-2}\right)$ faz com que seja atribuída importância diferenciada às áreas foliares presentes em cada avaliação, de acordo com a quantidade de irradiação disponível para as plantas. Resta saber se a diferença em absorção nas diferentes fases de desenvolvimento da cultura tem igual reflexo na produção, ou seja, se as folhas que mais absorveram energia serão as que mais fornecerão carboidratos para as partes reprodutivas das plantas (Silva et al., 1998; Diaz, 2000). 
A afirmação de Waggoner \& Berger (1987) de que a produção é determinada pela energia capturada pelo dossel das plantas durante a estação de cultivo é válida, porém a sua aplicação à cultura do feijoeiro necessita de maiores estudos.

Silva et al. (1998) sustentaram a idéia que ensaios que estudam os conceitos de $H A A\left(\mathrm{MJ} \mathrm{m}^{-2}\right)$ e utilizam-se de cultivares com crescimento semiindeterminado como o cultivar Carioca, considerando todas as folhas presentes nas plantas, pode ocasionar a superestimação da relação entre a energia absorvida pelas folhas e a produção da planta, pois as folhas maiores e mais velhas localizam-se na base da planta e apresentam taxas fotossintéticas decrescentes, já as folhas terminais encontram-se ainda em crescimento e conseqüentemente apresentam pouca translocação de fotoassimilados para os órgãos reprodutivos. Nesse caso, os fotoassimilados produzidos são utilizados para o crescimento das próprias folhas (Sache \& Zadoks, 1994).
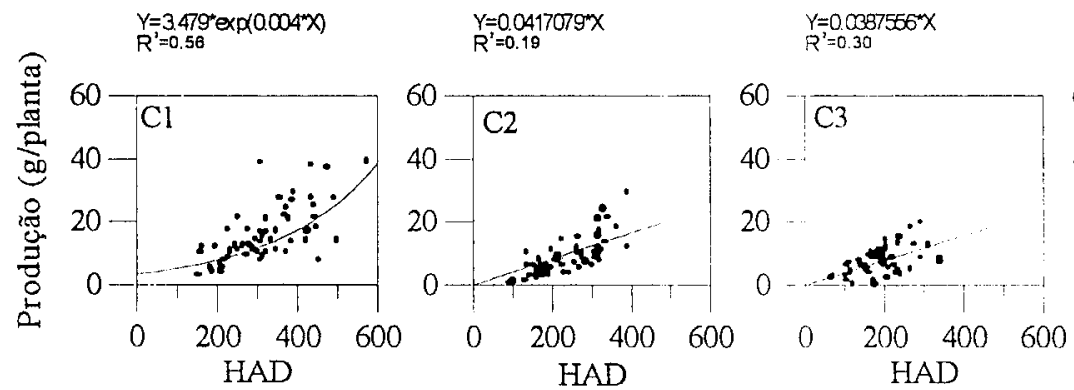

$Y=2.9311^{*} \exp \left(0005^{*} X\right)$
$R^{\prime}=0.56$

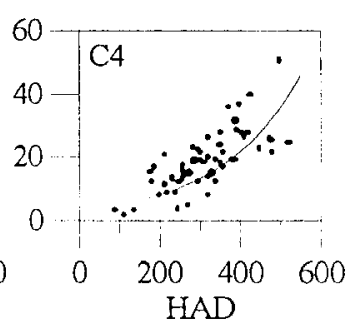

Figura 12 - Relação entre $H A D$ (dias) e produção (gramas por planta) dos experimentos C1, C3 (ferrugem - oxycarboxin), C2 e C4 (mancha angular - trifenil hidróxido de estanho) do feijoeiro. Piracicaba, São Paulo, 1998 2000 . 


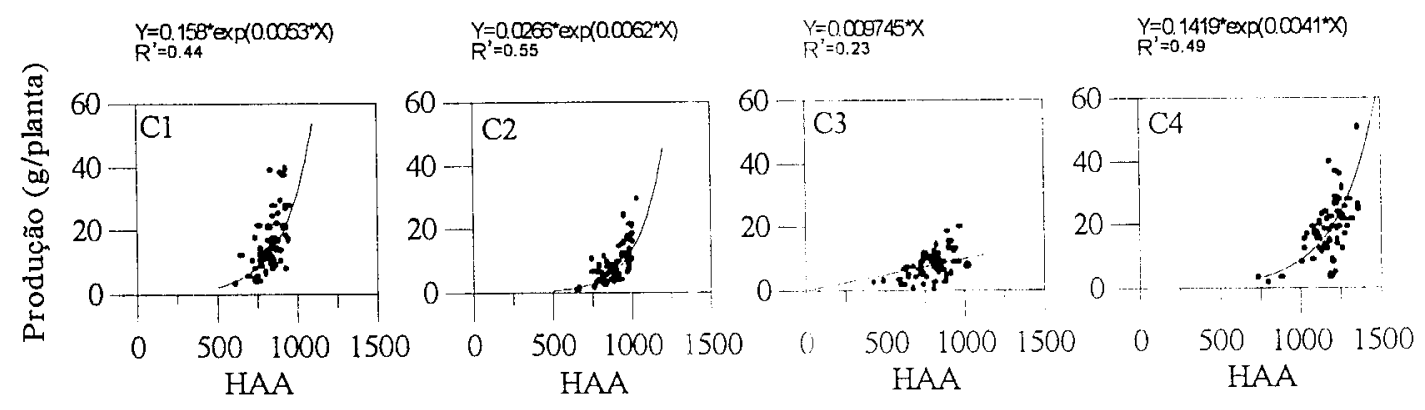

Figura 13 - Relação entre $H A A\left(\mathrm{MJ} \mathrm{m}^{-2}\right)$ e produção (gramas por planta) dos experimentos $\mathrm{C} 1, \mathrm{C} 3$ (ferrugem - oxycarboxin), C2 e C4 (mancha angular trifenil hidróxido de estanho) do feijoeiro. Piracicaba, São Paulo, 1998 2000.

Diante das diferentes relações obtidas entre as variáveis $H A D$ (dias) e $H A A\left(\mathrm{MJ} \mathrm{m}^{-2}\right)$ versus produção (gramas/planta), realizou-se uma análise conjunta dos dados de forma a obter uma única equação que representasse todos os experimentos mesmo realizados em épocas diferentes (Figuras 14 e 15).

Todas as relações entre $H A D$ (dias) e produção (gramas/planta) dos experimentos foram primeiramente ajustadas ao modelo linear e posteriormente ao modelo exponencial de forma a obter uma única equação que representasse todos os experimentos. $\mathrm{O}$ melhor ajuste foi obtido pelo modelo linear (com passagem forçada através da origem) cujo coeficiente de determinação foi de 0,48 . A equação obtida foi: Produção=0,0502*HAD (Figura 14).

A forma da curva obtida da relação entre $H A D$ (dias) e produção é dependente de uma série de fatores como $H L A I$, a senescência natural ou provocada pelas doenças, além de outras condições edafo-climáticas presentes durante a condução dos experimentos. 


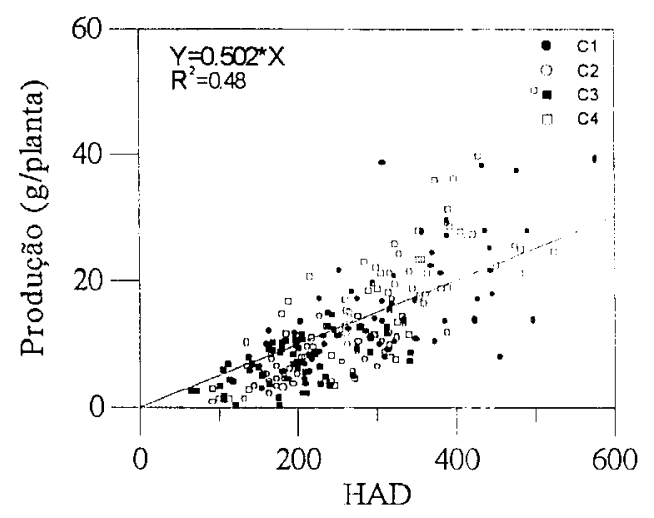

Figura 14 - Análise conjunta dos dados entre $H A D$ (dias) e produção (gramas/planta) dos experimentos $\mathrm{C} 1, \mathrm{C} 3$ (ferrugem - oxycarboxin), $\mathrm{C} 2$ e $\mathrm{C} 4$ (mancha angular - trifenil hidróxido de estanho). Piracicaba, São Paulo, 1998 2000 .

De igual forma aos dados de $H A D$ (dias), realizou-se uma análise conjunta entre os dados de $H A A\left(\mathrm{MJ} \mathrm{m}^{-2}\right)$ com a produção gramas/planta dos quatro experimentos. O melhor ajuste encontrado foi o exponencial com coeficiente de determinação de 0,32. A equação sugerida foi: Produção=0,8925* $\exp \left(0,0026^{*} H A A\right)$ (Figura 15).

Observando a tendência dos pontos apresentados na Figura 15, fica mais uma vez comprovado que a variável $H A A\left(\mathrm{MJ} \mathrm{m}^{-2}\right)$ é influenciada em grande parte pela radiação solar incidente, já que durante a condução dos experimentos $\mathrm{C} 2$ e C4 a radiação solar encontrava-se em média próxima aos valores de $17,96 \mathrm{MJ} \mathrm{m}^{-2}$ por dia, proporcionando unidades de $H A A\left(\mathrm{MJ} \mathrm{m}^{-2}\right)$ em média de $1000 \mathrm{MJ} \mathrm{m}^{-2}$ por dia. Diante destes resultados pode-se pensar na possibilidade de analisar conjuntamente os dados obtidos da relação entre $H A A\left(\mathrm{MJ} \mathrm{m}^{-2}\right)$ e produção (gramas/planta) na cultura do feijoeiro, obtidos em estudos anteriores de forma a obter equações que representem as 
variações na radiação solar existente durante as estações do ano. Estes resultados poderiam ser utilizados em sistemas para a tomada de decisão de acordo com as diferenças na radiação.

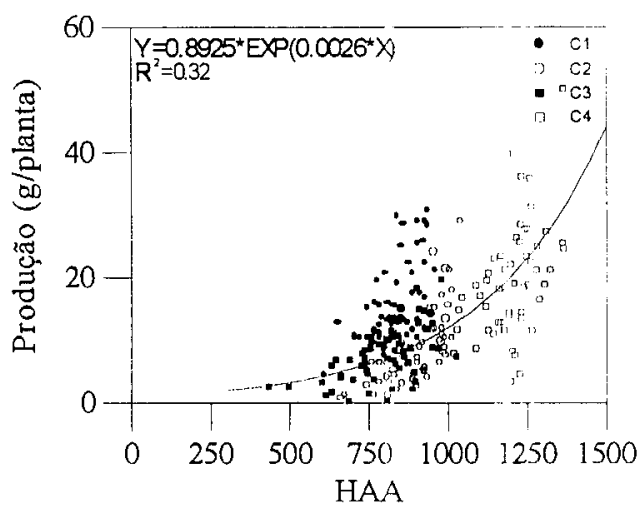

Figura 15 - Análise conjunta dos dados entre $H A A\left(\mathrm{MJ} \mathrm{m}^{-2}\right)$ e produção (gramas/planta) dos experimentos C1, C3 (ferrugem - oxycarboxin), C2 e C4 (mancha angular - trifenil hidróxido de estanho). Piracicaba, São Paulo, $1998-2000$.

\section{4 Área foliar Sadia (HLAI), Radiação Interceptada pela Área Foliar Sadia (HRI) e Porcentagem de Desfolha}

Os resultados presentes neste trabalho mostraram a superioridade do uso das variáveis $H A D$ (dias) e $H A A\left(\mathrm{MJ} \mathrm{m}^{-2}\right)$ sobre a $A U D P C$ para a quantificação de danos dos patossistemas ferrugem e mancha angular do feijoeiro. O conceito de $H A D$ (dias) e $H A A\left(\mathrm{MJ} \mathrm{m}^{-2}\right)$ foi considerado por muitos (Berger, 1988; Johnson, $1990 \mathrm{e}$ Kranz \& Jorg, 1989; Gaunt, 1995b) como o caminho ideal, ou o único (Johnson, 1992) que poderá suprir interpretações reproduziveis de danos nas culturas induzidas por infestações complexas de múltiplas doenças e pestes (Bergamin Filho et al., 1997). 
Para a tomada de decisão, entretanto, variáveis integrais como $H A D$ (dias) e $H A A\left(\mathrm{MJ} \mathrm{\textrm {m } ^ { 2 }}\right)$ não são as mais apropriadas segundo Madden \& Nutter Jr. (1995). Talvez seja melhor, segundo Bergamin Filho et al., (1997), desenvolver modelos mais empíricos do tipo de ponto-crítico usando HLAI ou HRI (MJ m²), estimando produção em vários períodos durante a estação de crescimento, do que integrar automaticamente essas variáveis e obter $H A D$ (dias) e $H A A\left(\mathrm{MJ} \mathrm{m}^{-2}\right)$.

Na Figura 16, estão representados os valores do Índice de Área Foliar Sadio (HLAI) para os experimentos C1, C3 (ferrugem - oxycarboxin), C2 e C4 (mancha angular - trifenil hidróxido de estanho) do feijoeiro.

Pode-se notar que os valores máximos do $H L A I$ ficaram em torno de 9,24 unidades de HLAI aos 69 DAP (T5) para o experimento (C1) (sexta avaliação); 7,52 unidades de HLAI para o experimento C2 (quarta avaliação), tratamento T5 aos 46 DAP; 4,19 unidades de HLAI para o experimento C3 (T4) aos 73 DAP (quinta avaliação) e 7,28 unidades de $H L A I$ para o experimento C4 (T2) aos 52 DAP (quarta avaliação).

Bergamin Filho et al. (1997) observaram, no patossistema mancha angular - feijão, que nem sempre as parcelas que não foram inoculadas (plantas com maiores valores de $H L A I$ ) apresentavam baixas porcentagens de severidade, fato este também observado nestes experimentos.

Os elevados valores de HLAI obtidos de experimentos semelhantes a estes foram atribuídos, por Canteri et al. (1997), à alta fertilidade da área experimental e aos baixos níveis de severidade das doenças, apesar dos experimentos terem sido conduzidos em épocas favoráveis ao desenvolvimento de epidemias.

Nos experimentos com o patossistema ferrugem - feijão os valores de HLAI no tratamento T5 (plantas mais sadias) e T1 (plantas mais doentes) tiveram valores crescentes até a sexta avaliação (69 DAP) (C1). Já no experimento C3, os valores de $H L A I$ foram crescentes até a sexta avaliação (81 DAP) para o tratamento T1 e até a quinta avaliação (73 DAP) para o tratamento T5 (Figura 16).

No experimento C2 (mancha angular - trifenil hidróxido de estanho) os valores de HLAI das plantas sadias (T5) foram crescentes até a quarta avaliação (46 
DAP). De igual forma o tratamento mais doente (T1) também teve sua área foliar reduzida a partir dos 46 DAP. Já para o experimento C4 (mancha angular - trifenil hidróxido de estanho) os maiores valores de HLAI do tratamento T5 e também os menores valores de $H L A I$ do tratamento $\mathrm{T} 1$ aumentaram até a quarta avaliação, isto é aos 52 DAP (Figura 6).

Estes dados diferiram dos resultados obtidos por Godoy (1995) neste mesmo patossistema. A autora constatou que o HLAI das plantas sadias aumentou até a quinta avaliação (54 DAP), sendo que nas plantas doentes esta queda foi observada na quarta avaliação (49 DAP) devido a um processo de desfolha precoce ocorrido em relação ao ciclo da cultura. Nos experimentos C2 e C4 este fenômeno não foi observado, apesar das diferenças existentes nos valores de $A U D P C$ dos diferentes tratamentos.
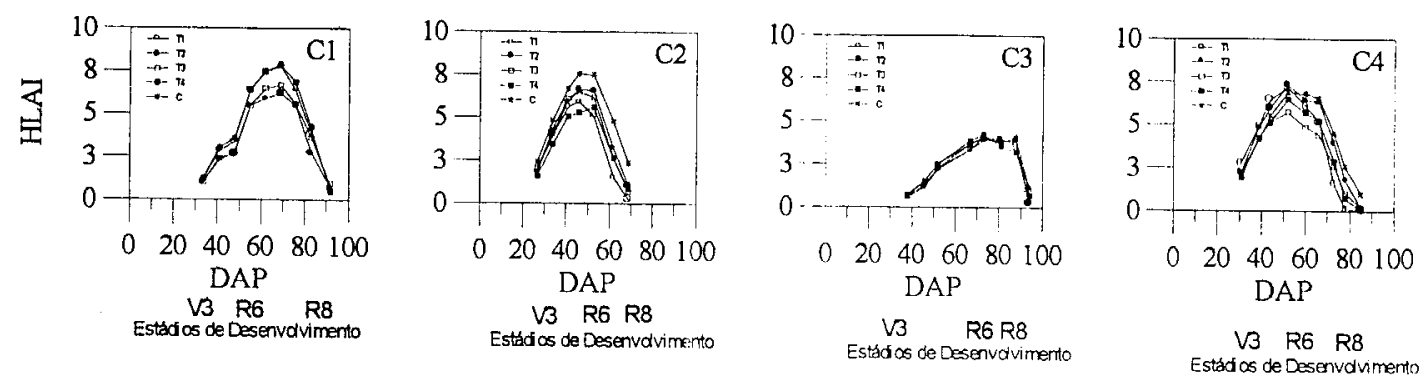

Figura 16 - Efeito da ferrugem - oxycarboxin (experimentos C1 e C3) e mancha angular - trifenil hidróxido de estanho (experimentos $\mathrm{C} 2$ e $\mathrm{C} 4$ ) do feijoeiro sobre o indice de área foliar sadio (HLAD). Piracicaba, São Paulo, 1998 2000.

Diante destes resultados e observando as Figuras 9,17 e 21 , fica evidente que mesmo o tratamento $\mathrm{T} 1$, que recebeu duas inoculações de Uromyces 
appendiculatus e Phaeoisariopsis griseola e nenhuma aplicação com fungicida, não apresentou desfolha acentuada $(36,28 \%$ para $\mathrm{C} 1 ; 35,80 \%$ para $\mathrm{C} 2 ; 21,0 \%$ para $\mathrm{C} 3 \mathrm{e}$ $48,5 \%$ para $\mathrm{C} 4$ ), mesmo no patossistema mancha angular - feijão, que possui como característica marcante a desfolha provocada pela doença. A desfolha ficou apenas evidente no experimento $\mathrm{C} 1$, onde os tratamentos $\mathrm{T} 2$ e $\mathrm{T} 3$ apresentaram valores de desfolha estatisticamente semelhantes aos do tratamento $\mathrm{T} 1 \quad(34,64 \% ; 34,67 \%$ e $36,28 \%$ respectivamente) e também no experimento $\mathrm{C} 2$ em que os tratamentos T2 e T3 apresentaram valores de porcentagem de desfolha semelhantes ao tratamento $\mathrm{T} 1$ $(36,80 \%, 39,07 \%$ e $35,80 \%$, respectivamente).
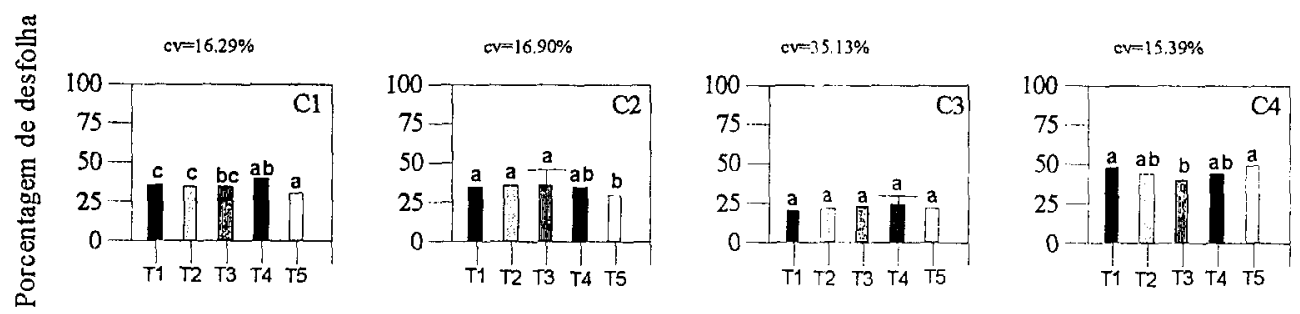

Figura 17 - Porcentagem média de desfolha $( \pm$ desvio padrão de 12 plantas por tratamento) obtida dos experimentos $\mathrm{C} 1, \mathrm{C} 3$ (ferrugem - oxycarboxin), $\mathrm{C} 2 \mathrm{e}$ C4 (mancha angular - trifenil hidróxido de estanho) do feijoeiro. Médias seguidas de mesma letra não diferem significativamente entre si pelo teste de Tukey $(p<0,05)$. Piracicaba, São Paulo, 1998 - 2000.

Quando a desfolha foi relacionada com a produção, foi observado que a produção esteve associada ao aumento da desfolha. Essa relação foi razoavelmente descrita pelo modelo exponencial em todos os experimentos, com $R^{2}$ de 0,22 : Produção $=55,994^{*} \exp \left(-0,0408^{*}\right.$ Desfolha $\left.(\%)\right)$ para o experimento $\mathrm{Cl} ; \mathrm{R}^{2}$ de 0,28 : Produção $=66,476^{*} \exp \left(-0,0637^{*}\right.$ Desfolha $\left.(\%)\right)$ para o experimento $C 2 ; R^{2}$ de 0,17 : 
Produção $=15,482 * \exp \left(-0,0365^{*}\right.$ Desfolha $\left.(\%)\right)$ para o experimento $\mathrm{C} 3$ e de $\mathrm{R}^{2} 0,21$ : Produção $=88,828^{*} \exp \left(-0,0368^{*}\right.$ Desfolha $\left.(\%)\right)$ para o experimento C4 (Figura 18).

Gianasi (1999) encontrou em apenas um dos três experimentos realizados com a antracnose do feijoeiro a relação exponencial entre a porcentagem de desfolha e a produção: Produção=55,994* $\exp \left(-0,0408^{*}\right.$ Desfolha $\left.(\%)\right)$ com coeficiente de determinação de 0,60 ). O mesmo modelo aplicado aos outros experimentos produziu valores de $\mathrm{R}^{2}$ baixos, não evidenciando relação entre desfolha e produção.
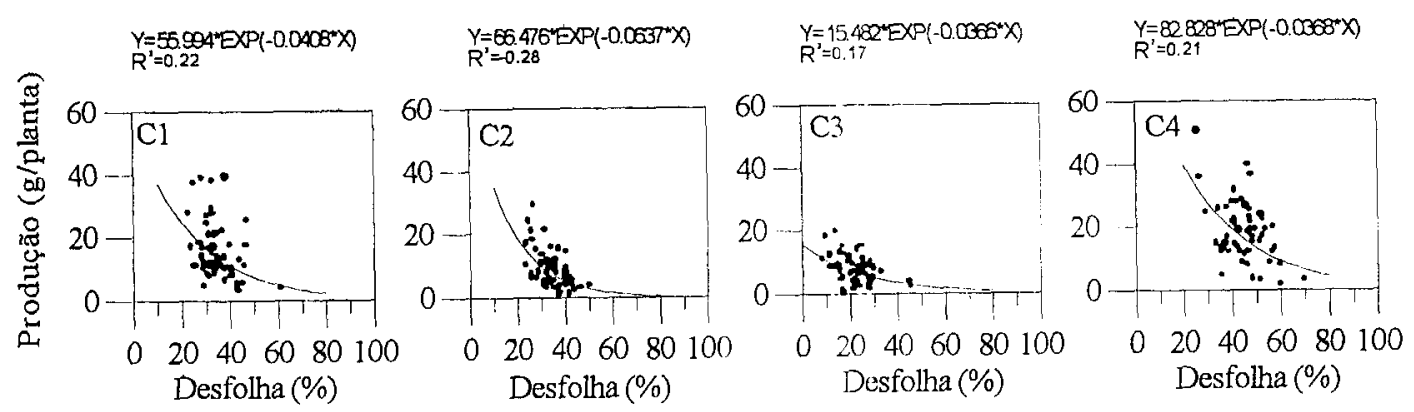

Figura 18 - Produção (gramas por planta) versus porcentagem de desfolha, para plantas individuais de feijão infectadas com ferrugem $(\mathrm{C} 1$ e $\mathrm{C} 3$ ) e mancha angular (C2 e C4) (60 plantas por experimento). Piracicaba, São Paulo, 1998 2000.

Outro fator que deve ser ressaltado é que em alguns tratamentos o número de folhas emitidas não foi significativamente diferente em alguns experimentos como o $\mathrm{C} 3$ e $\mathrm{C} 4$. No experimento $\mathrm{C} 1$, o tratamento $\mathrm{T} 5$ foi o que apresentou o maior número de folhas emitidas $(6,06)$, seguido do tratamento T2 e posteriormente do T3 e T1. Já no experimento $\mathrm{C} 2$, foi o tratamento $\mathrm{T} 1$ que emitiu o maior número de folhas $(5,47)$, seguido pelos tratamentos T3 e T5. 
Madeira et al. (1988), analisando o patossistema Ascochyta fabae Vicia faba, observaram que parcelas com plantas infectadas mostraram uma queda mais acentuada no índice de área foliar do que nas parcelas de plantas sadias, sugerindo a senescência precoce. A aceleração da senescência das folhas já tem sido apontada como uma das maiores causas da redução da área foliar verde em alguns patossistemas, como a pinta preta e a murcha de Verticillium em batata (Johnson et al., 1987) e a mancha foliar em alfafa por Stemphylum botryosum (Basu, 1976).

Nota-se que independente da aplicação semanal com os fungicidas, o tratamento 5 apresentou pouco ganho no número de folhas emitidas durante o período de condução dos experimentos quando comparado ao tratamento T1 que não recebeu nenhuma aplicação com fungicida (Figura 19).

$\mathrm{O}$ pico do número de folhas emitidas no experimento $\mathrm{C} 1$ foi aos 55 DAP para os tratamentos T1, T3, T4 e T5 (10,33 $\pm 2,6 ; 10,17 \pm 2,01 ; 12,92 \pm 0,93$ e $11,0 \pm 1,1$, respectivamente) e aos 48 DAP para o tratamento T2 $(8,42 \pm 0,63)$. Já para o experimento $\mathrm{C} 2$, o pico do número de folhas emitidas deu-se aos 41 DAP para o tratamento T1 $(8,25 \pm 1,29)$, aos 34 DAP para os tratamentos T2, T3 e T4 (7,25 \pm 1,86; $7,67 \pm 1,08$ e 7,5 $\pm 0,73)$ e aos 46 DAP para o tratamento T5 (7,92 $\pm 0,73)$. No experimento C3 o pico máximo no número de folhas emitidas foi aos 52 DAP para todos os tratamentos $(\mathrm{T} 1: 7,75 \pm 2,0 ; \mathrm{T} 2: 8,58 \pm 0,95 ; \mathrm{T} 3: 9,17 \pm 0,23 ; \mathrm{T} 4: 9,25 \pm 1,37$ e T5: 8,67 $\pm 1,53)$. Já para o experimento $C 4$, com exceção do tratamento T1, todos os demais tratamentos apresentaram o maior número de folhas aos 44 DAP (T2: 9,89 \pm 2,62; T3: 8,67 $\pm 2,49 ; \mathrm{T} 4: 10,0 \pm 0,41$ e T5: 10,11 \pm 0,28). O pico no número de folhas emitidas no tratamento T1 foi de 9,67 \pm 0,31 aos 39 DAP (Fgura 20).

Deste modo pode-se dizer que a desfolha causada pelas doenças foi compensada pela emissão de folhas novas até a maturidade. Este fenômeno também foi observado por Pixley et al. (1990).

Carneiro et al. (2000) conseguiram detectar diferenças na porcentagem de desfolha quando estudaram a interação entre a mancha angular e a antracnose do feijoeiro, graças ao número de folhas emitidas pelas plantas durante o ciclo da cultura. 
O fato do cultivar Carioca emitir novas folhas deve-se provavelmente ao hábito de crescimento Tipo III ou semi-indeterminado (Portes, 1988), isto é, possui guias mais longas, com ramos laterais bem desenvolvidos e numerosos. A produção de folhas novas é uma característica do cultivar, que pode afetar a translocação de fotoassimilados para as vagens.

Silva et al. (1998) constataram que nos experimentos inoculados com $P$. griseola ocorreram maiores reduções no número de folhas nas plantas quando comparados com experimentos inoculados com Colletotrichum lindemuthianum e Uromyces appendiculatus. Esse fenômeno só foi observado no experimento $\mathrm{C} 1$ (ferrugem - oxycarboxin) no qual o tratamento T5 apresentou o número máximo de folhas emitidas.

Um fato a ser enfatizado é a associação entre número de folhas emitidas e produção. Pixley et al. (1990), estudando o patossistema Cercosporidium personatum - amendoim, observou que o número de folhas emitidas nas plantas levou a um gasto de energia que limitou a quantidade de fotoassimilados disponíveis para o crescimento das vagens de amendoim. No presente trabalho observando as Figuras $7 \mathrm{e}$ 19, do experimento C2, o tratamento T1 apresentou um maior número de folhas e conseqüentemente foi o que produziu menos (4,92 gramas/planta). Já os experimentos C3 e C4 apresentaram números de folhas semelhantes a todos os tratamentos (sem diferença estatística significativa entre si p>0,05) refletindo, portanto na produção, com valores também sem significância estatística.

Uma possível explicação para este fenômeno é que algumas plantas mais doentes crescidas ao lado de outras com menores porcentagens de severidade da doença, dentro de um mesmo tratamento, lançavam folhas novas na tentativa de compensar o dano provocado pelo patógeno, que na somatória final se igualavam aos tratamentos que recebiam número maior de aplicações com os fungicidas. Esse fenômeno pode ser facilmente observado no experimento $\mathrm{C} 2$, onde o tratamento $\mathrm{T} 1$ foi o que apresentou maior número de folhas emitidas, seguido do tratamento T3.

Portes (1988) lembra-nos ainda que folhas jovens funcionam mais como dreno do que como fonte de fotoassimilados e sua porcentagem de translocação 
aumenta com a idade e atinge valores de 60-70\% quando a folha está completamente expandida. Assim, uma folha jovem depende das folhas expandidas para seu crescimento.

Carneiro (1999) sugere que outros trabalhos sejam feitos com a capacidade do cultivar Carioca em compensar a desfolha
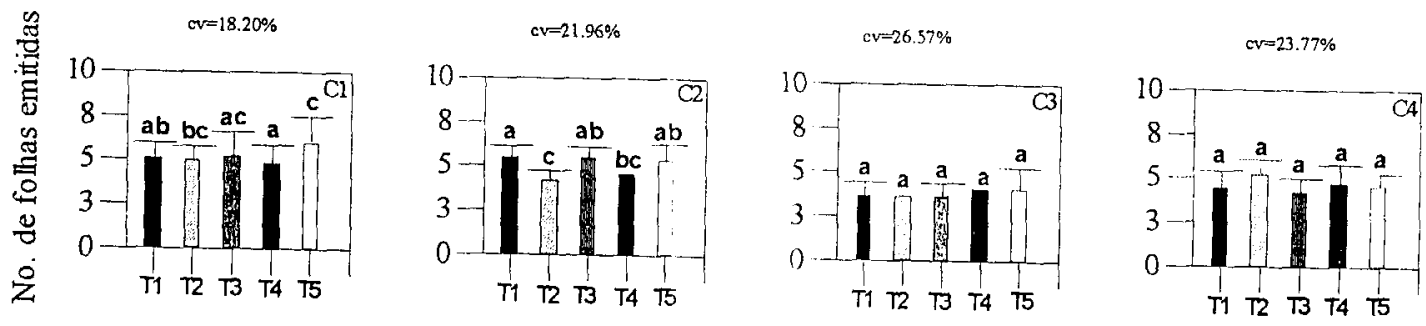

Figura 19 - Número de folhas emitidas obtidas dos experimentos $\mathrm{C} 1, \mathrm{C} 3$ (ferrugem oxycarboxin), C2 e C4 (mancha angular - trifenil hidróxido de estanho) do feijoeiro. Médias \pm desvio padrão de 12 plantas por tratamento. Médias seguidas de mesma letra não diferem significativamente entre si pelo teste de Tukey $(p<0,05)$. Piracicaba, São Paulo, 1998 - 2000
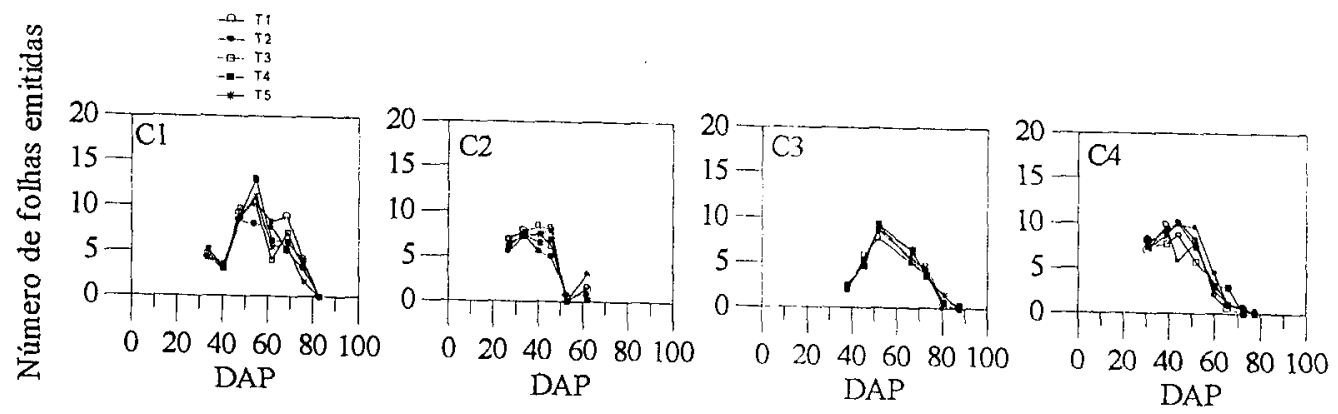

Figura 20 - Curvas de progresso do número de folhas emitidas em função dos experimentos C1, C3 (ferrugem - oxycarboxin), C2 e C4 (mancha angular - trifenil hidróxido de estanho) do feijoeiro. Médias \pm desvio padrão de 12 plantas por tratamento. Médias seguidas de mesma letra não diferem significativamente entre si pelo teste de Tukey $(p<0,05)$. Piracicaba, São Paulo, 1998 - 2000. 

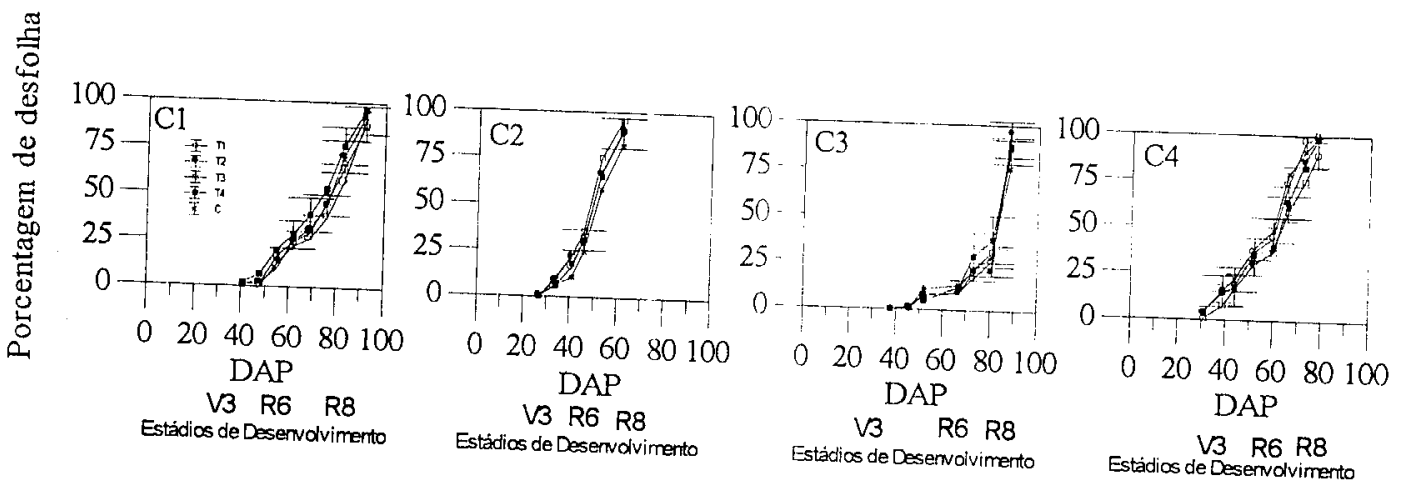

Figura 21 - Porcentagens de desfolha em função do tempo obtidas dos experimentos $\mathrm{Cl}, \mathrm{C} 3$ (ferrugem - oxycarboxin), C2 e C4 (mancha angular - trifenil hidróxido de estanho) do feijoeiro. Médias \pm desvio padrão de 12 plantas por tratamento. Médias seguidas de mesma letra não diferem significativamente entre si pelo teste de Tukey $(p<0,05)$. Piracicaba, São Paulo, 1998 - 2000.

Quando o índice de área foliar sadio (HLAD) foi relacionado com a produção (gramas/planta), os melhores ajustes encontrados foram obtidos com equações lineares com passagem forçada pela origem (Figura 22). As equações encontradas nos experimentos $\mathrm{C} 1, \mathrm{C} 2, \mathrm{C} 3$ e $\mathrm{C} 4$, foram respectivamente: Produção=3,691*HLAI $\quad\left(\mathrm{R}^{2}=0,48\right) ; \quad$ Produção=2,32*HLAI $\quad\left(\mathrm{R}^{2}=0,53\right)$; Produção=3,10*HLAI $\left(\mathrm{R}^{2}=0,24\right)$ e Produção=4,83*HLAI $\left(\mathrm{R}^{2}=0,57\right)$. 

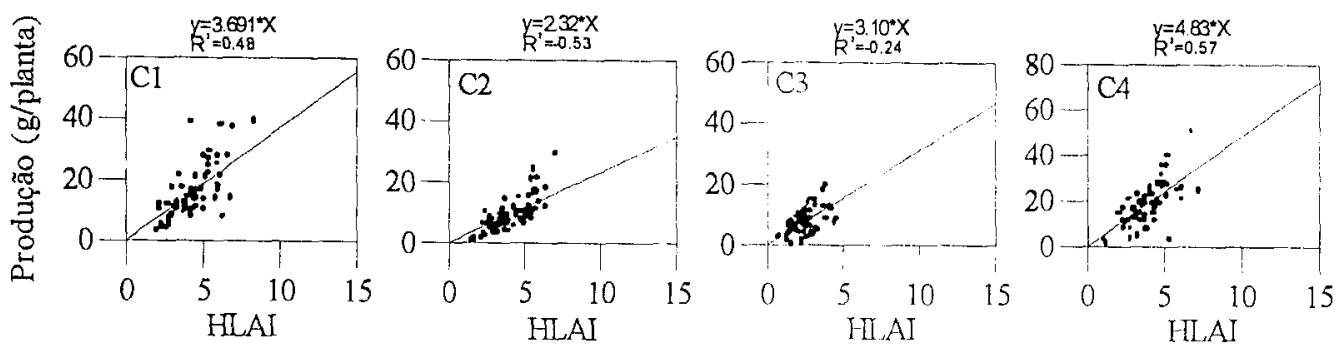

Figura 22 - Relação entre $H L A I$ (dias) e produção (gramas por planta) dos experimentos C1, C3 (ferrugem - oxycarboxin), C2 e C4 (mancha angular trifenil hidróxido de estanho do feijoeiro. Piracicaba, São Paulo, 1998 2000 .

Realizou-se também uma análise conjunta entre os dados de HLAI com a produção de todos os experimentos de forma a definir uma única equação que representasse todos os ensaios. A equação apresentada foi: Produção=0,2347*HLAI com coeficiente de determinação de 0,42 (Figura 23)

De igual forma aos dados de $H A D$ (dias), a forma da curva da relação entre $H L A I$ e produção é dependente de fatores como a senescência natural ou provocada pelas doenças além de condições edafo-climáticas presentes durante a condução dos experimentos.

$\mathrm{Na}$ Figura 24 estão representados os valores da Radiação Interceptada pela Porção Sadia da Planta (HRI) dos experimentos C1, C3 (ferrugem - oxycarboxin), $\mathrm{C} 2$ e C4 (mancha angular - trifenil hidróxido de estanho) do feijoeiro.

Os maiores valores de $H R I\left(\mathrm{MJ} \mathrm{m}^{-2}\right)$ no experimento $\mathrm{Cl}$ foi obtido no tratamento T1 $(15,80)$ e no tratamento T5 $(16,38)$, ambos obtidos aos 69 DAP. Já para o experimento $\mathrm{C} 2$, os maiores valores de $H R I\left(\mathrm{MJ} \mathrm{m}^{-2}\right)$ foram obtidos aos 46 DAP tanto para o tratamento $\mathrm{T} 1(23,45)$ quanto para o tratamento T5 $(24,24)$. No experimento $\mathrm{C} 3$ os maiores valores de $H R I\left(\mathrm{MJ} \mathrm{m}^{-2}\right)$ foram obtidos em ambos os tratamentos T1 e T5 aos $81 \mathrm{DAP}(14,93$ e 16,01, respectivamente). Já no experimento 
$\mathrm{C} 4$ os maiores valores de $H R I\left(\mathrm{MJ} \mathrm{m}^{-2}\right)$ foram alcançados aos $44 \mathrm{DAP}$ com valores de 22,94 e 22,77 para os tratamentos T1 e T5, respectivamente (Figura 24).

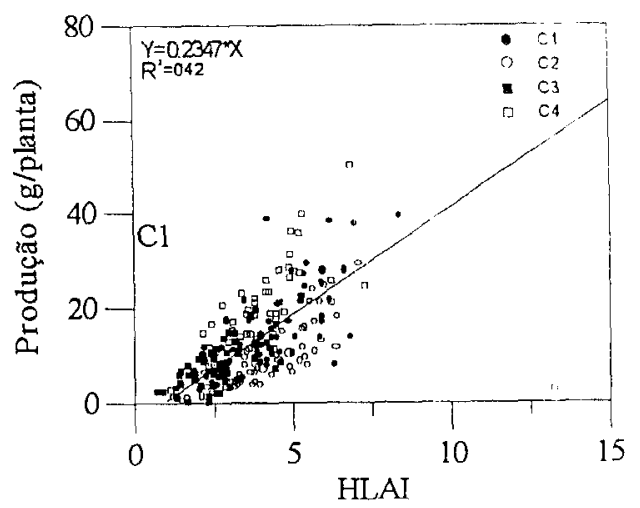

Figura 23 - Análise conjunta dos dados entre $H L A I$ e produção (gramas/planta) dos experimentos C1, C3 (ferrugem - oxycarboxin), C2 e C4 (mancha angular trifenil hidróxido de estanho). Piracicaba, São Paulo, 1998 - 2000.
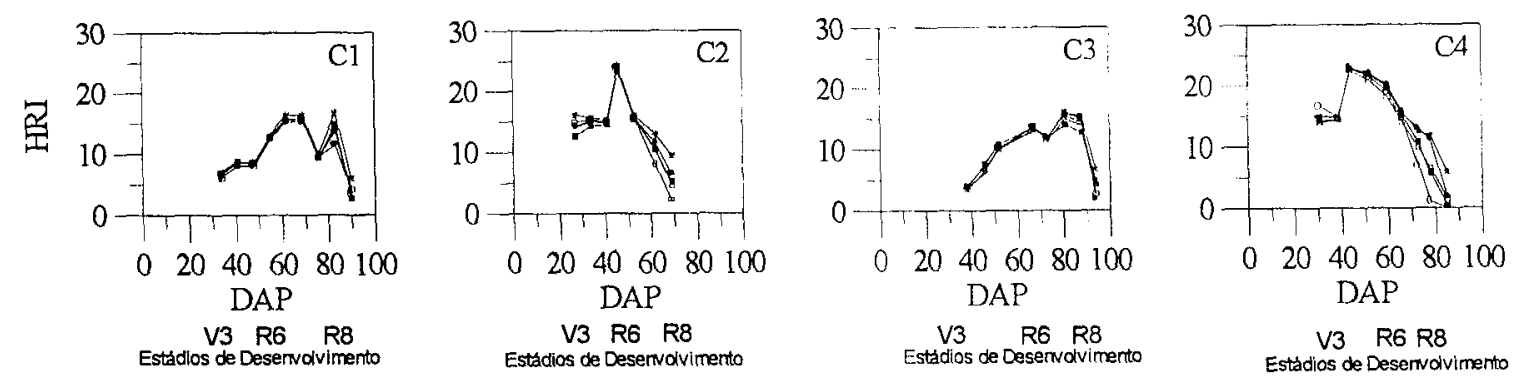

Figura 24 - Efeito da ferrugem - oxycarboxin (experimentos C1 e C3) e mancha angular - trifenil hidróxido de estanho (experimentos $\mathrm{C} 2$ e $\mathrm{C} 4$ ) do feijoeiro sobre a radiação interceptada pela área foliar sadia por unidade de tempo (HRI, MJ m ${ }^{-2}$ ). Médias de 12 plantas por tratamento. Piracicaba, São Paulo, 1998-2000. 
Na Figura 25 estão representadas as relações entre $H R I\left(\mathrm{MJ} \mathrm{m}^{-2}\right) \mathrm{e}$ produção para os quatro experimentos. Nota-se que os dados de apenas um (C3) dos quatro experimentos realizados tiveram o melhor ajuste quando se utilizou a equação linear (Produção=0,81*HRI com $\left.\mathrm{R}^{2}=0,28\right)$. Já os dados dos demais experimentos $(\mathrm{C} 1$, $\mathrm{C} 2$ e C4) se ajustaram melhor quando se utilizaram os ajustes exponenciais. Os coeficientes de determinação dos ajustes exponencıais dos experimentos C1, C2 e C4 foram respectivamente de: 0,$47 ; 0,56$ e 0,41 , sendo as equações: Produção=0,2824* $\exp \left(0,3634^{*} H R I\right) ; \quad$ Produção=0,2824* $\exp \left(0,3634^{*} H R I\right)$; Produção=0,0377* $\exp \left(0,3673^{*} H R D\right)$ e Produção=0,5415*exp $\left(0,2367^{*} H R I\right)$.
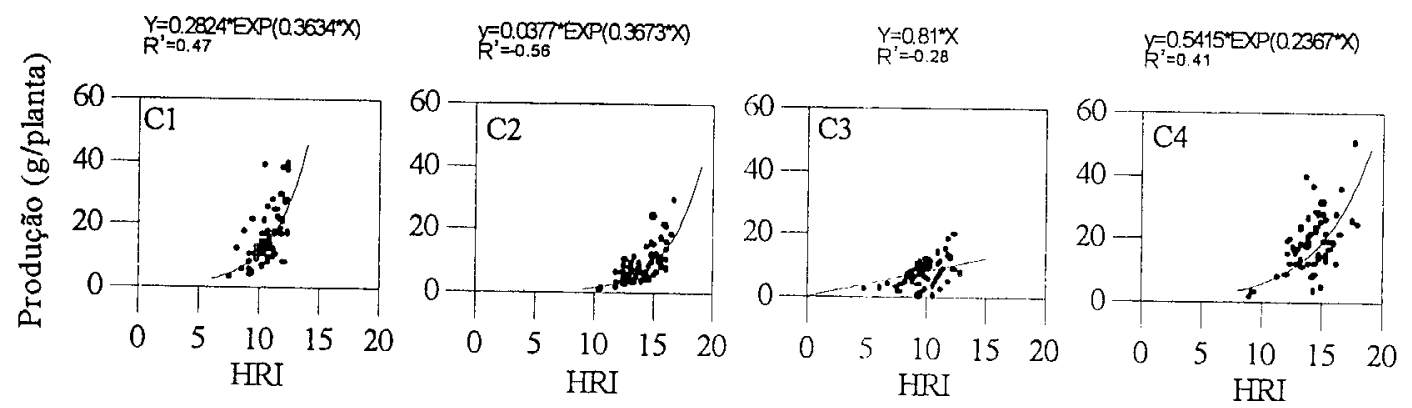

Figura 25 - Relação entre $H R I\left(\mathrm{MJ} \mathrm{m}^{-2}\right)$ e produção (gramas por planta) dos experimentos $\mathrm{C} 1, \mathrm{C} 3$ (ferrugem - oxycarboxin), C2 e C4 (mancha angular trifenil hidróxido de estanho) do feijoeiro. Piracicaba, São Paulo, 1998 2000.

Diante das curvas entre HRI (MJ m ${ }^{-2}$ ) e produção (gramas por planta) terem apresentado tendências exponenciais e lineares procurou-se primeiramente ajustar todo os dados dos quatro experimentos em curvas exponenciais e, posteriormente, em ajustes lineares de forma a obter uma única equação que 
representasse todos os experimentos. $O$ melhor ajuste encontrado foi o exponencial com coeficiente de determinação de 0,37 . A equação proposta é: Produção=2,1051*exp $\left(0,1273^{*} H R D\right.$ ) (Figura 26).

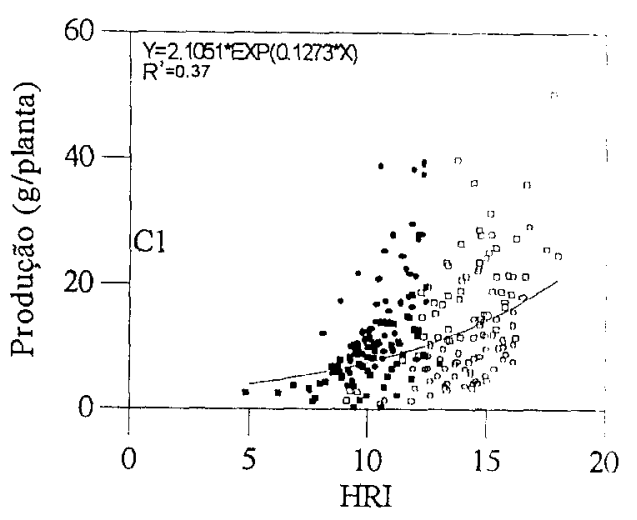

Figura 26 - Análise conjunta dos dados entre $H R I\left(\mathrm{MJ} \mathrm{m}^{-2}\right.$ ) e produção (gramas/planta) dos experimentos C1, C3 (ferrugem - oxycarboxin), C2 e C4 (mancha angular - trifenil hidróxido de estanho). Piracicaba, São Paulo, 1998 - 2000 .

\subsection{Limiar de Dano Econômico: A Tomada de Decisão}

Segundo Bergamin Filho et al. (1997), $H R I\left(\mathrm{MJ} \mathrm{m}^{-2}\right)$ é a variável que melhor se relaciona com a produção, portanto seria mais indicada para o uso em programas de manejo de doenças. Porém, esta variável é dependente da radiação solar incidente ( $($ ) e esta pode variar entre estações de cultivo. Este fenômeno é facilmente detectado neste trabalho quando observamos as radiações solares médias do período de condução dos experimentos $\left(\mathrm{C} 1=13,43 \mathrm{MJ}^{-2}\right.$ por dia; $\mathrm{C} 2=17,33 \mathrm{MJ}^{-2}$ por dia; $\mathrm{C} 3=14,34 \mathrm{MJ}^{-2}$ por dia e $\mathrm{C} 4=18,59 \mathrm{MJ}^{2}$ por dia).

Seguindo a sugestão de Bergamin Filho et al. (1997) e Gianasi (1999), realizou-se regressões lineares com passagem forçada através da origem entre os 
valores individuais de $H L A I$ e $H R I\left(\mathrm{MJ} \mathrm{m}^{-2}\right)$ para os diferentes estádios de crescimento (GS) do feijoeiro e a produção (gramas/planta) para todos os experimentos (Tabela 9). Assim como descrito por Bergamin Filho et al. (1997), os coeficientes angulares das retas entre HLAI e a produção (passagem forçada pela origem) dos experimentos apresentaram-se muito variáveis no estádio V3 (primeira folha trifoliolada): médias \pm desvios padrões de $14,11 \pm 0,99$ para $\mathrm{C} 1,12,07 \pm 0,8$ para $\mathrm{C} 2$; 4,75 \pm 0,32 para C3; 6,14 $\pm 0,53$ para C4 (Tabela 9).

Para os experimentos C1 e C3, a estabilização dos valores ficou entre os estádios R5 - R8: média \pm desvio padrão: 4,99 \pm 0,33; 2,61 $\pm 0,15 ; 2,22 \pm 0,12 ; 3,52 \pm$ 0,18 para $\mathrm{C} 1 ; 3,28 \pm 0,21 ; 3,23 \pm 0,11 ; 2,02 \pm 0,11 ; 1,99 \pm 0,12$ para C3 Aparentemente a menor curva apresentada (experimento C3) está relacionada com as plantas mais doentes, isto é aquelas que apresentaram valores de $A U D P C$ maiores $(18,48 \pm 4,82)$. Já para os experimentos C2 e C4 os coeficientes angulares das retas iniciaram as estabilizações mais antecipadamente, isto é entre os estádios V4 - R8 (média \pm desvio padrão): $2,20 \pm 0,14 ; 1,57 \pm 0,09 ; 1,45 \pm 0,08 ; 1,53 \pm 0,07 ; 2,93 \pm$ 0,15 para $\mathrm{C} 2$ e $3,3 \pm 0,16 ; 2,81 \pm 0,12 ; 3,26 \pm 0,11 ; 5,07 \pm 0,33 ; 7,47 \pm 1,05$ para $\mathrm{C} 4$ (Tabela 9 e Figura 27).

Bergamin Filho et al. (1997), estudando o patossistema mancha angular - feijão, encontraram a inclinação das curvas entre $H L A I$ e produção estáveis ao redor dos estádios de desenvolvimento R5 - R8. Da mesma forma Gianasi (1999), estudando o patossistema antracnose - feijão, também encontrou a estabilização dos coeficientes angulares entre R5 - R8. 
Tabela 9. Coeficientes angulares $(+$ erro padrão) das retas de regressão (passagem forçada através da origem) entre produção (gramas/planta) e índice de área foliar sadio (HLAI) e entre produção (gramas/planta) e radiação interceptada pela área foliar sadia $\left(H R I, \mathrm{MJ} \mathrm{m}^{-2}\right)$, em diferentes estádios de crescimento do feijoeiro (GS), quantificados no patossistema ferrugem (C1 e C3) e mancha angular (C2 e C4). Piracicaba, São Paulo, 1998 - 2000.

\begin{tabular}{|c|c|c|c|c|c|c|c|c|}
\hline \multirow[t]{2}{*}{$\mathrm{GS}^{1}$} & \multicolumn{4}{|c|}{ HLAI } & \multicolumn{4}{|c|}{ HRI $\left(\mathrm{MJ} \mathrm{m}^{-2}\right)$} \\
\hline & C1 & $\mathrm{C} 2$ & C3 & $\mathrm{C} 4$ & $\mathrm{C} 1$ & $\mathrm{C} 2$ & C3 & $\mathrm{C} 4$ \\
\hline $\mathrm{V}_{3}$ & $14,11 \pm 0,99$ & $4,75 \pm 0,32$ & $12,07 \pm 0,8$ & $6,14 \pm 0,53$ & $2,74 \pm 0,20$ & $0,63 \pm 0,04$ & $2,06 \pm 0,13$ & $1,25 \pm 0,07$ \\
\hline $\mathrm{V}_{4}$ & $5,79 \pm 0,39$ & $2,20 \pm 0,14$ & $5,61 \pm 0,37$ & $\begin{array}{c}3,30 “ \pm \\
0,16\end{array}$ & $1,14 \pm 0,15$ & $0,59 \pm 0,04$ & $1,13 \pm 0,06$ & $0,82 \pm 0,05$ \\
\hline $\mathrm{R}_{5}$ & $4,99 \pm 0,33$ & $1,57 \pm 0,09$ & $3,28 \pm 0,21$ & $2,81 \pm 0,12$ & $0,90 \pm 0,15$ & $0,59 \pm 0,04$ & $0,69 \pm 0,04$ & $0,87 \pm 0,05$ \\
\hline $\mathrm{R}_{6}$ & $2,61 \pm 0,15$ & $1,45 \pm 0,08$ & $3,23 \pm 0,12$ & $3,26 \pm 0,11$ & $0,73 \pm 0,08$ & $0,47 \pm 0,03$ & $0,68 \pm 0,03$ & $0,99 \pm 0,05$ \\
\hline $\mathrm{R}_{7}$ & $2,22 \pm 0,12$ & $1,53 \pm 0,07$ & $2,02 \pm 0,11$ & $5,07 \pm 0,33$ & $0,69 \pm 0,11$ & $0,37 \pm 0,04$ & $0,52 \pm 0,04$ & $0,79 \pm 0,10$ \\
\hline $\mathrm{R}_{8}$ & $3,52 \pm 0,18$ & $2,93 \pm 0,15$ & $1,99 \pm 0,12$ & $7,47 \pm 1,05$ & $1,0 \pm 0,10$ & $0,66 \pm 0,05$ & $0,55 \pm 0,03$ & $0,90 \pm 0,19$ \\
\hline $\mathrm{R}_{9}$ & $10,19 \pm 1,24$ & $5,22 \pm 0,51$ & $5,15 \pm 0,66$ & $13,47 \pm 3,35$ & $1,52 \pm 0,39$ & $1,21 \pm 0,1$ & $1,0 \pm 0,03$ & $1,55 \pm 0,54$ \\
\hline
\end{tabular}

florescimento; $R_{6}=$ Florescimento; $R=$ formação das vagens; $R=$ enchimento das vagens e $\mathrm{R}=$ maturidade fisiológica (Michaelis, 1994). 


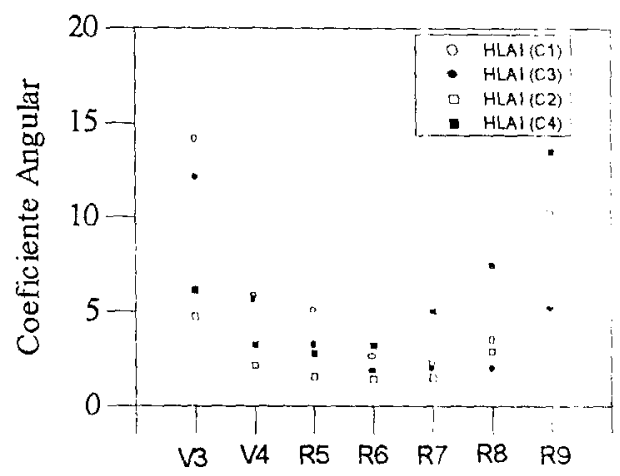

Figura 27 - Coeficientes angulares obtidos pela regressão linear, com passagem forçada pela origem da produção (gramas por planta) com índice de área foliar sadio (HLAI) medidos nos estádios de crescimento do feijoeiro infectado com a ferrugem $(\mathrm{C} 1, \mathrm{C} 3)$ e mancha angular $(\mathrm{C} 2, \mathrm{C} 4)$. Estádios de crescimento: $V_{3}=$ primeira folha trifoliolada; $V_{4}=$ terceira folha trifoliolada; $\mathrm{R}_{5}=$ pré - florescimento; $\mathrm{R}_{6}=$ florescimento; $\mathrm{R}_{7}=$ formação das vagens; $R_{8}=$ enchimento das vagens e $R_{9}=$ maturidade fisiológica (Michaelis, 1994). Piracicaba, São Paulo, 1998 - 2000.

Observando agora os coeficientes angulares das retas produzidas através de regressões lineares com passagem forçada através da origem, entre a produção (gramas por planta) e $H R I\left(\mathrm{MJ} \mathrm{m}^{-2}\right.$ ) (Figura 28), observa-se que a estabilização dos

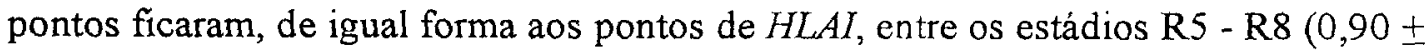
$0,15 ; 0,73 \pm 0,08 ; 0,69 \pm 0,11$ e $1,0 \pm 0,10)$ para o experimento $\mathrm{Cl}$ e também entre os estádios R5 - R8 $(0,69 \pm 0,04 ; 0,68 \pm 0,03 ; 0,52 \pm 0,04$ e 0,55 $\pm 0,03)$ para 0 experimento C3. Já para o experimento $\mathrm{C} 2$ a estabilização ficou entre os estádios V4 R8 $(0,59 \pm 0,04 ; 0,59 \pm 0,04 ; 0,47 \pm 0,03 ; 0,37 \pm 0,04$ e $0,66 \pm 0,05$. Já para o 
experimento C4, a estabilização também ficou entre os estádios V4 - R8 (0,82 £ 0,05; $0,87 \pm 0,05 ; 0,99 \pm 0,05 ; 0,79 \pm 0,10$ e $0,90 \pm 0,19)$ (Figura 28 Tabela 9).

Bergamin Filho et al., (1997) encontraram a estabilização entre HRI (MJ m² ${ }^{-2}$ e produção nos estádios R5 - R8, no patossistema mancha angular - feijão. De igual forma, Gianasi (1999) também encontrou em seus dados a estabilização entre os estádios R5 - R8, quando estudou o patossistema antracnose - feijão.

Estes resultados promissores obtidos anteriormente por Bergamin Filho et al. (1997) e Gianasi (1999) indicavam que $H A A\left(\mathrm{MJ} \mathrm{m}^{-2}\right)$, através de sua variável diária $H R I\left(\mathrm{MJ} \mathrm{m}^{-2}\right)$, seria adequada para uso em sistemas de manejo de doenças do feijoeiro. Entretanto Carneiro et al. (1999), apesar da incorporação do parâmetro ß na estimativa de $H A A\left(\mathrm{MJ} \mathrm{m}^{-2}\right)$ e melhora no modelo, obteve resultados inválidos para diferentes safras, cultivares e anos.

Deste modo, parece que tanto HLAI como HRI $\left(\mathrm{MJ} \mathrm{m}^{-2}\right)$ incorporam as condições ideais para se tornar uma variável explanatória imprescindível para a implementação de um sistema de manejo de doenças. Este sistema pode ser usado para produzir recomendações precisas a nível de campo. Para isto, Lopes et al (1994) propuseram a adoção de uma parcela controle livre de doença. Cada situação de produção deve ser mais a homogênea possível, no que se refere a fatores que influenciam a produção, como tipo de solo, microclima, práticas culturais e cultivar. Baseando-se na relação entre produção $H L A I$ e $H R I\left(\mathrm{MJ} \mathrm{m}^{-2}\right)$ e usando de informações sobre a influência de medidas de controle e dos custos envolvidos, um novo e conceitual nível de dano pode ser determinado. Esse nível não mais será expresso em insetos por planta ou severidade de doença, ambos de relação incerta com a produção (Waggoner \& Berger, 1987), mas em unidades de HLAI e HRI ( $\mathrm{MJ}^{-2} /$ planta).

Deste modo, medidas de controle somente seriam recomendadas quando a diferença entre a HLAI ou HRI $\left(\mathrm{MJ} \mathrm{m}^{-2}\right)$ da parcela controle e $H L A I$ ou $H R I\left(\mathrm{MJ} \mathrm{m}^{-2}\right)$ da cultura for igual ou superior ao nível de dano (Lopes et al., 1994).

Devido à inexistência de dados sobre o efeito de medidas de controle sobre a HLAI e HRI (MJ m $\left.{ }^{-2}\right)$ da ferrugem e da mancha angular, salvo os trabalhos de Bergamin Filho et al. (1997) com a mancha angular e Gianasi (1999) com a antracnose 
do feijoeiro, um valor aproximado do grau de sensibilidade com o qual HLAI e HRI $\left(\mathrm{MJ} \mathrm{m}^{-2}\right)$ deve ser determinado para a tomada da decisão.

Utilizando-se do mesmo raciocínio de Bergamin Filho et al. (1997) e Gianasi (1999), tem-se que a estabilização dos coeficientes angulares obtidos da regressão linear com passagem forçada pela origem entre HLAI e produção (gramas/planta) dos experimentos com a ferrugem do feijoeiro foi entre os estádios R5 - $\mathrm{R} 8$, isto é ao redor de 2,98 $\pm 1,0$ unidades de HLAI. Isso significa que cada unidade de HLAI representa um incremento de produção de 2,98 g planta, ou 715,20 kg ha, considerando-se 240000 planta ha. Assim, se for considerado o custo de controle do Uromyces appendiculatus de $\$ 40$ ha (sugestão de Bergamin Filho et al., 1997 e Gianasi, 1999), isto equivale a aproximadamente $79 \mathrm{~kg}$ de feijão. Pode-se, então, estimar o limiar de dano econômico (LDE) em 79/715=0,11, ou aproximadamente 1/27 de uma unidade de HLAI. Já para os experimentos com a mancha angular, a estabilização dos coeficientes ficou entre os estádios V4 - R8, isto é ao redor de 3,159 $\pm 1,86$ unidades de HLAI, significando que cada unidade de HLAI representa um incremento de produção de 3,15 g planta, ou 756,00 kg ha, considerando-se 240000 planta ha. Assim, se for considerado o custo de controle de Phaeoisariopsis griseola de $\$ 40$ ha (sugestão de Bergamin Filho et al., 1997 e Gianasi, 1999), isto equivale a aproximadamente $79 \mathrm{~kg}$ de feijão, pode-se estimar o limiar de dano econômico (LDE) em 79/756=0,10, ou aproximadamente 1/32 de uma unidade de HLAI.

Já para os coeficientes angulares obtidos entre $H R I\left(\mathrm{MJ} \mathrm{m}^{-2}\right)$ e produção (gramas/planta), a estabilização dos coeficientes angulares ficou entre os estádios R5 R8 para os experimentos com a ferrugem, isto é redor de 0,72 $\pm 0,16$ unidades de $H R I$, significando que cada unidade de $H R I$ representa um aumento de produção de 0,72 g planta, ou 172,80 kg ha, considerando-se 240000 planta ha. Assim, se for considerado o custo de controle de Uromyces appendiculatus de $\$ 40$ ha equivalendo a aproximadamente $79 \mathrm{~kg}$ de feijão, pode-se estimar o limiar de dano econômico (LDE) em 79/172=0,45, ou aproximadamente $1 / 2$ unidade de $H R I$. Já para os experimentos com a mancha angular, a estabilização ficou entre os estádios V4 - R8, isto é ao redor de 0,70 \pm 0,20 g MJ de $H R I$, significando que cada unidade de HRI representa um 
incremento de produção de 0,70 g planta, ou 168,00 kg ha, considerando-se 240000 planta ha. Assim, se for considerado o custo de controle da Phaeoisariopsis griseola de $\$ 40$ ha, isto equivale a aproximadamente $79 \mathrm{~kg}$ de feijão, pode-se estimar o limiar de dano econômico (LDE) em 79/168=0,47, ou aproximadamente 0,67 de uma unidade de $H R I$.

Essa estimativa aproximada do limiar de dano econômico (LDE), igual a 1/27 de HLAI (ferrugem); 1/32 de HLAI (mancha angular); 1/2 de HRI (ferrugem) e 0,62 de $H R I$ (mancha angular), significa que a diferença entre a parcela controle e a situação de produção não poderia atingir 1/27 de HLAI (ferrugem); 1/32 de HLAI (mancha angular); 1/2 de HRI (ferrugem) e 0,67 de HRI (mancha angular)

Bergamin Filho et al. (1997) estimaram também o LDE em função da HLAI, que é a variável efetivamente quantificada no campo e encontraram os valores $1 / 20$ de $H L A I$ quando o $H L A I$ no campo for igual a 0,$2 ; 1 / 10$ para 1,$2 ; 1 / 5$ para 2,$2 ; 1 / 3$ para 2,$9 ; 1 / 2,5$ para 3,2;1/2 para 3,5 e 1/1 para 4,5. Em comparação com $H R I$, o HLAI tem a desvantagem de ser influenciado pela situação de produção.

O manejo integrado de doenças do feijoeiro pretende implementar um sistema de controle baseado num limiar de dano econômico. Bergamin Filho et al. (1997) e Gianasi (1999) estimaram um limiar de dano econômico para a mancha angular e antracnose do feijoeiro, respectivamente. Utilizando-se da mesma metodologia, pode-se deduzir que para o caso da mancha angular e ferrugem do feijoeiro, tal limiar dá-se quando ocorre a diferença da absorção da radiação pela área foliar sadia entre a parcela testemunha (tratamento T1) e a situação de produção (tratamento T5) for 1/27 de HLAI (ferrugem); 1/32 de HLAI (mancha angular); 1/2 de $H R I$ (ferrugem) e 0,62 de $H R I$ (mancha angular), significando que a diferença entre a parcela controle e a situação de produção não poderia atingir 1/27 de HLAI (ferrugem); 1/32 de HLAI (mancha angular); 1/2 de HRI (ferrugem) e 0,62 de HRI (mancha angular). 


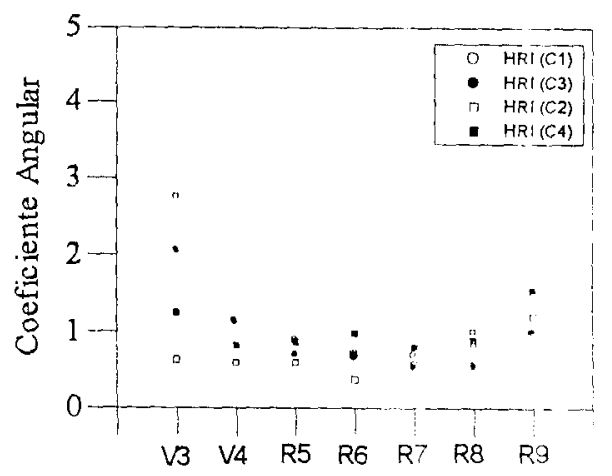

Figura 28 - Coeficientes angulares obtidos pela regressão linear, com passagem forçada pela origem da produção (gramas por planta) com radiação interceptada pela área foliar sadia por unidade de tempo $\left(H R I, \mathrm{MJ} \mathrm{m}^{-2}\right)$ medido nos estádios de crescimento do feijoeiro infectado com a ferrugem (C1 e C3) e mancha angular (C2 e C4). Estádios de crescimento: $\mathrm{V}_{3}=$ primeira folha trifoliolada; $V_{4}=$ terceira folha trifoliolada; $R_{5}=$ pré florescimento; $\mathrm{R}_{6}=$ florescimento; $\mathrm{R}_{7}=$ formação das vagens; $\mathrm{R}_{\mathbf{8}}=$ enchimento das vagens e $R_{9}=$ maturidade fisiológica (Michaelis, 1994). Piracicaba, São Paulo, 1998 - 2000.

Passou-se então a analisar a parcela controle (T5), comparada ao tratamento $\mathrm{T} 1$. Vale lembrar que a parcela controle é definida como uma situação de produção na qual a cultura é mantida livre de doença. Vale ressaltar que nesses experimentos não se conseguiu manter o tratamento $T 5$ livre totalmente de doença. $O$ motivo para tal evento pode ser explicado pela presença de inóculo inicial presente na área dos experimentos, além da pressão de inóculo exercida pelos demais tratamentos (T1, T2, T3 e T4) que receberam duas inoculações artificiais com urediniósporos e conídios da ferrugem e mancha angular. Os fungicidas utilizados (oxycarboxin e trifenil hidróxido de estanho) demonstraram efeito protetor e não curativo, o que 
permitiu a ocorrência de severidade das doenças em todos os tratamentos, inclusive na parcela controle (T5).

A variação de $H L A I, \Delta_{H L A I}=H L A I$ Parcela controle $-H L A I$ testemunha, para o experimento C1 (ferrugem - oxycarboxin), foi de -0,26 aos 48 DAP e de 0,43 aos 55 DAP (estádios R5 - R6), demonstrando que o LDE para a situação de produção foi alcançado entre as avaliações dos 48 e 55 DAP. Já para o experimento C2 (mancha angular - trifenil hidróxido de estanho), o LDE foi alcançado entre os 27 e 34 DAP (estádios V3 - V4) (0,47 e 0,9, respectivamente). No experimento C3 (ferrugem oxycarboxin), o LDE foi alcançado entre os 67 e 73 DAP (estádios R5 - R6) (-0,023 e 0,177) e finalmente no experimento C4 (mancha angular - trifenil hidróxido de estanho), o LDE foi alcançado entre os 52 e 60 DAP (R5-R6) (-0,26 e 0,63) (Figura 29).

Vale ressaltar que na época que o LDE foi atingido, isto é entre os estádios R5-R6 (C1), V3-V4 (C2), R5-R6 (C3) e entre os estádios R5-R6 (Michaelis, 1994) para o experimento C4, a ausência de medidas de controle nestes estádios pode resultar em severos danos à produção.

Este mesmo raciocínio foi atribuído à variável $H R I$, onde variação de $H R I, \Delta_{H R I}=H R I$ Parcela controle $-H L A I$ testemunha, para o experimento $\mathrm{C} 1$ (ferrugem oxycarboxin), foi de -0,13 aos 34 DAP e de 0,19 aos 41 DAP (estádios V3 - V4), demonstrando que o LDE para a situação de produção foi alcançado entre as avaliações dos 34 e 41 DAP. Já para o experimento C2 (mancha angular - trifenil hidróxido de estanho), o LDE foi alcançado, igualmente a HLAI, isto é, entre os 27 e 34 DAP (estádios V3 - V4) (1,80 e 0,81, respectivamente). No experimento C3 (ferrugem - oxycarboxin), o LDE foi alcançado entre 38 e 46 DAP (estádios V4 - R5) $(0,0$ e 0,39$)$ e finalmente no experimento C4 (mancha angular - trifenil hidróxido de estanho), o LDE foi alcançado entre os 44 e 52 DAP (R5-R6) (-0,17 e 0,62) (Figura 30).

Novamente vale ressaltar que a época na qual o LDE foi atingido, isto é entre os estádios V3-V4 (C1), V3-V4 (C2), V4-R5 (C3) e entre os estádios R5-R6 para 
o experimento C4, a ausência de medidas de controle nestes estádios (Michaelis, 1994) pode resultar em severos danos à produção.

Gianasi (1999) trabalhando com a antracnose do feijoeiro, obteve o LDE entre os estádios V4-R5 para dois de seus experimentos, semelhante ao ocorrido no experimento $\mathrm{C} 3$.
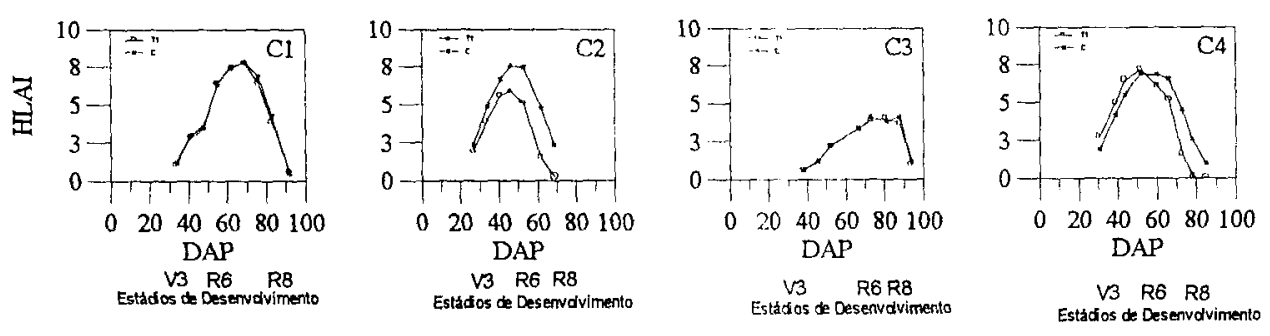

Figura 29 - Índice de Área Foliar Sadio (HLAD) do feijoeiro infectado com a ferrugem ( $\mathrm{Cl}$ e C3) e mancha angular ( $\mathrm{C} 2$ e C4) para os tratamentos $\mathrm{T} 1$ (s/ pulverização com fungicidas e com duas inoculações artificiais em intervalo de 10 dias) e T5 (aplicações semanais de fungicida e sem inoculação). Piracicaba, São Paulo, 1998 2000.
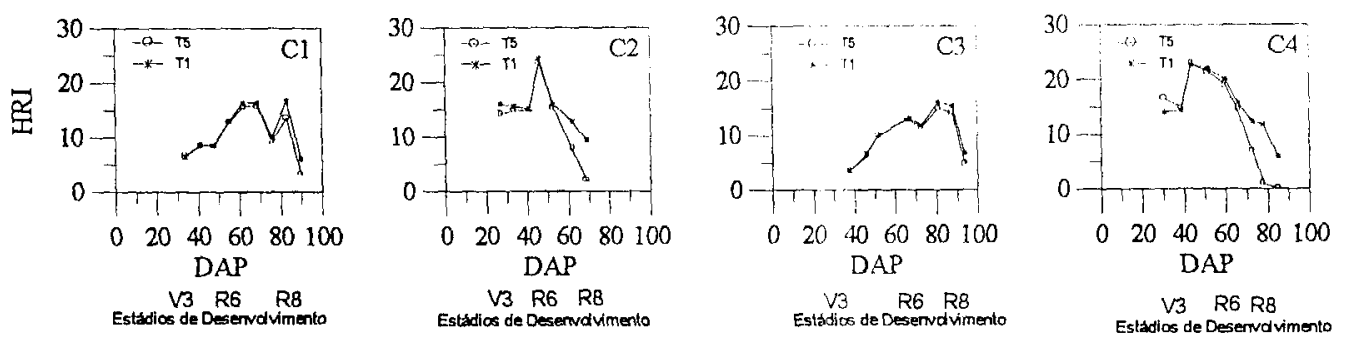

Figura 30 - Radiação Interceptada pela área foliar sadia por unidade de tempo (HRD) do feijoeiro infectado com a ferrugem (C1 e C3) e mancha angular (C2 e C4) para os tratamentos $\mathrm{T} 1$ (s/ pulverização com fungicidas e com duas inoculações artificiais em intervalo de 10 dias) e T5 (aplicações semanais de fungicida e sem inoculação). Piracicaba, São Paulo, 1998 - 2000. 
Baseando-se nestes experimentos ( $\mathrm{C} 1, \mathrm{C} 2, \mathrm{C} 3$ e $\mathrm{C} 4)$ e também no trabalho de Gianasi (1999), pode-se dizer que a implementação de um sistema de manejo integrado baseado no LDE parece bastante viável para a cultura do feijoeiro. Entretanto alguns pontos devem ser esclarecidos para que a abordagem de danos possa ser utilizada no contexto de doenças do feijoeiro.

No presente trabalho, devido à pouca influência da quantidade de doença na área foliar e conseqüentemente pouca influência na produção, não permitiu resultados conclusivos quanto ao LDE baseados nestas variáveis. Para melhor definição do LDE, necessita-se conhecer mais sobre a eficiência dos tratamentos fungicidas para o controle da ferrugem e mancha angular do feijoeiro. O presente ensaio demonstrou relação entre porcentagem de controle e época de inícios dos tratamentos.

Para obedecer à exigência da tomada de decisão baseando-se na utilização de variáveis não integrais como HLAI e $H R I$, faz-se necessário lançar novos desafios aos futuros pesquisadores desta abordagem. Este desafio inclui o acompanhamento da cultura durante todas as fases de desenvolvimento, além da determinação da proporção de área foliar doente, facilitada com o auxílio de escalas diagramáticas, além de medição do índice de área foliar ( $L A I)$, seja diretamente com a determinação da maior largura do folíolo central das folhas de cada planta marcada ou através de equipamentos eletrônicos como os radiômetros de múltiplo espectro ou de ceptômetros.

Pensando nesta hipótese realizou-se, paralelamente às avaliações manuais da área foliar, avaliações com um ceptômetro de forma a realizar comparações entre as duas medições do índice de área foliar e possivelmente recomendar o uso do ceptômetro em sistemas de manejo integrado da cultura do feijoeiro. 
4.6 Comparação dos dados do Índice de Área entre Foliar (LAI) obtidos de avaliações diretas (LAI Manual) e indiretas com o Ceptômetro (LAI Ceptômetro)

Conforme enunciado no item 3.2 (Avaliações do Desenvolvimento do Hospedeiro, Severidade da Doença e Produção), para evitar os possíveis danos decorrentes nos momentos das avaliações, cada parcela foi dividida em duas partes, sendo a primeira metade (1S) destinada às medições manuais da área foliar $(\mathrm{cm}) \mathrm{e}$ porcentagem de severidade da doença e a segunda metade (2S) foi destinada às medições com o ceptômetro.

Neste item serão apresentados os dados do índice de área foliar (LAI) obtidos através de medições diretas da área foliar (LAI Manual) da subdivisão da parcela $1 \mathrm{~S}$ e os dados de $L A I$ obtidos através de medições indiretas com o ceptômetro na subdivisão de parcela $2 \mathrm{~S}$ (LAI Ceptômetro).

Nas Tabelas 10, 11, 12 e 13 e Figuras 31, 32, 33 e 34 estão representadas as comparações dos valores dos Índices de Área Foliar obtidos diretamente através de medições manuais da área foliar das plantas (LAI Manual) e dos Índices de Área Foliar obtidos indiretamente através de medições com o Ceptômetro (LAI Ceptômetro) dos experimentos C1, C3 (ferrugem - oxycaboxin), C2 e C4 (mancha angular - trifenil hidróxido de estanho), obtidos durante as avaliações semanais.

No experimento C1 (ferrugem - oxycarboxin) foram realizadas sete avaliações com o ceptômetro, sendo elas aos 34, 41, 55, 62, 76, 83 e 92 dias após o plantio (DAP). Pode-se observar que em todos os tratamentos as curvas obtidas diretamente (LAI Manual) e indiretamente (LAI Ceptômetro) apresentaram muito próximas apenas nas avaliações iniciais e finais, isto é aos 34, 41, 83 e 92 DAP em todos os tratamentos. Nas demais avaliações o ceptômetro subestimou os valores do LAI em pelo menos duas vezes (Tabela 10 e Figura 31 ).

Já no experimento C2 (mancha angular - trifenil hidróxido de estanho), foram realizadas seis avaliações com o ceptômetro, sendo elas aos 34, 41, 46, 53, 62 e 69 DAP. Observa-se que os índices de área foliar obtidos com o ceptômetro ficaram bem próximos às avaliações diretas nas seis avaliações realizadas, entretanto pode-se 
notar que o ceptômetro continuou subestimando os valores do LAI em todos os tratamentos, com maior evidência nos tratamentos T3 e T5 (Tabela 11e Figura 32).

Tabela 10. Dados dos Índices de Área Foliar obtido de avaliações diretas da área foliar (LAI Manual) e indiretamente com o ceptômetro (LAI Ceptômetro) do experimento C1 (ferrugem - oxycarboxin). Piracicaba, São Paulo, 1998 2000

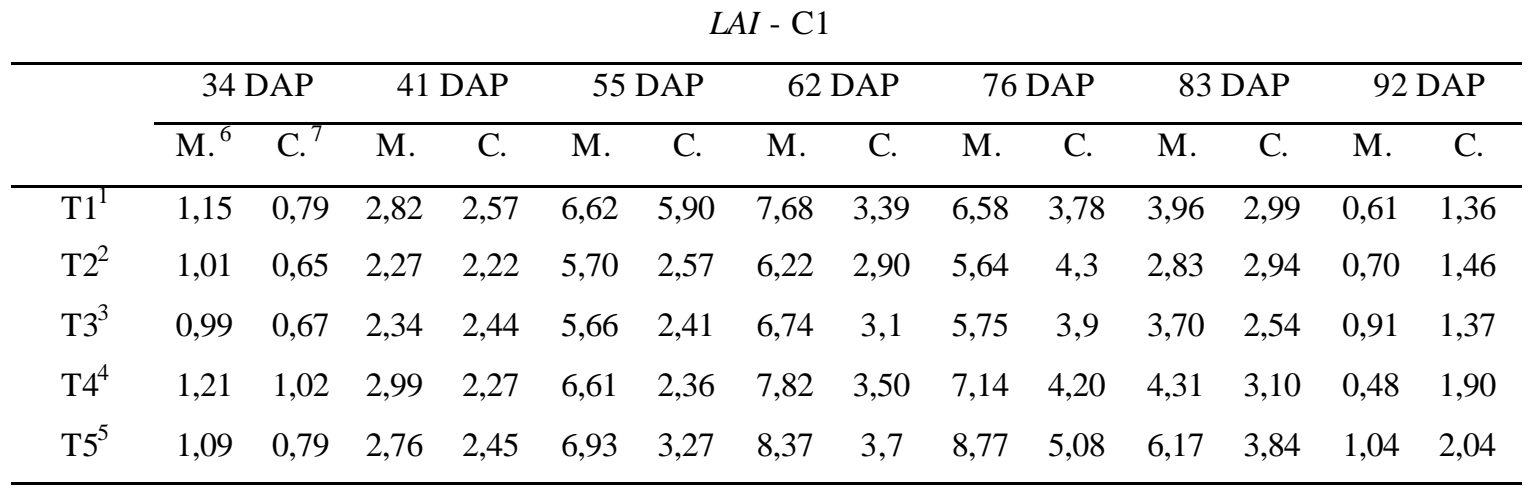

\footnotetext{
${ }^{1} \mathrm{~T} 1: \mathrm{s} /$ pulverização com fungicidas e com duas inoculações artificiais em intervalo de 10 dias;

${ }^{2} \mathrm{~T} 2$ : primeira pulverização no estádio $\mathrm{R}_{5}$ (pré - floração) e repetida uma única vez após 14 dias com duas inoculações artificiais em intervalo de 10 dias;

${ }^{3}$ T3: pulverização iniciada no estádio $\mathrm{R}_{6}$ (floração) e repetida uma única vez após 14 dias com duas inoculações artificiais em intervalo de 10 dias;

${ }^{4}$ T4: pulverização iniciada no estádio $\mathrm{R}_{5}$ (pré - floração) e continuada a cada 14 dias até as plantas terem atingido o estádio $\mathrm{R}_{6}$ (floração) com duas inoculações em intervalo de 10 dias;

${ }^{5}$ T5: aplicações semanais de fungicida e sem inoculação;

${ }^{6}$ Valores do LAI correspondente a média de 12 plantas;

${ }^{7}$ Valores do LAI correspondente a média de seis leituras.
} 

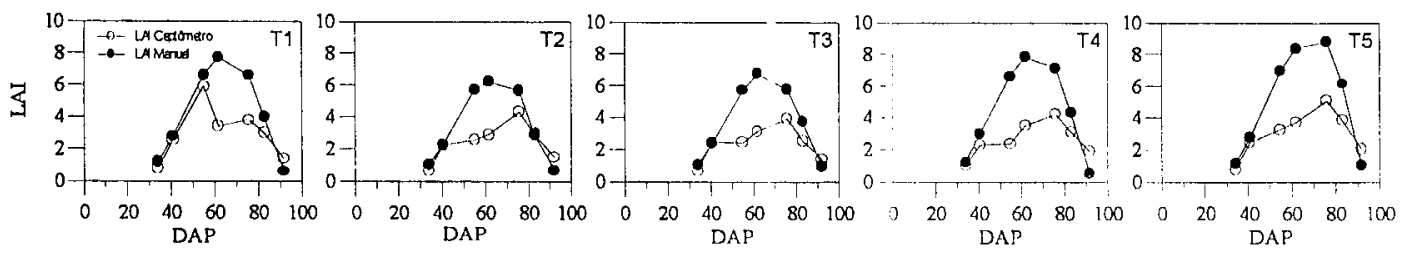

Figura 31 - Estimativas comparativas dos Índices de Área Foliar obtido através de medições diretas da área foliar ( $L A I$ Manual) e indiretamente com ceptômetro ( $L A I$ Ceptômetro) do experimento $\mathrm{Cl}$ (ferrugem - oxycarboxin). Piracicaba, São Paulo, 1998 - 2000.

Tabela 11. Dados dos Índices de Área Foliar obtido de avaliações diretas da área foliar (LAI Manual) e indiretamente com o ceptômetro ( $L A I$ Ceptômetro) do experimento $\mathrm{C} 2$ (mancha angular - trifenil hidróxido de estanho). Piracicaba, São Paulo, 1998 2000 .

$L A I-\mathrm{C} 2$

\begin{tabular}{|c|c|c|c|c|c|c|c|c|c|c|c|c|}
\hline & \multicolumn{2}{|c|}{34 DAP } & \multicolumn{2}{|c|}{$41 \mathrm{DAP}$} & \multicolumn{2}{|c|}{$46 \mathrm{DAP}$} & \multicolumn{2}{|c|}{$53 \mathrm{DAP}$} & \multicolumn{2}{|c|}{62 DAP } & \multicolumn{2}{|c|}{69 DAP } \\
\hline & $\mathrm{M}^{6}$ & $\mathrm{C}^{7}$ & $\mathrm{M}^{6}$ & $\mathrm{C}^{\top}$ & $\mathrm{M}^{6}$ & $\mathrm{C}^{7}$ & $\bar{M}^{6}$ & $\mathrm{C}^{7}$ & $\mathrm{M}^{6}$ & $\mathrm{C}^{7}$ & $M^{6}$ & $\mathrm{C}^{7}$ \\
\hline $\mathrm{T} 1^{1}$ & 3,93 & $1, \overline{56}$ & 5,62 & 4,05 & 5,91 & 5,23 & 5,09 & 4,40 & 1,64 & 0,78 & 0,25 & 0,12 \\
\hline $\mathrm{T} 2^{2}$ & 4,10 & 1,34 & 5,90 & 4,01 & 6,64 & 6,1 & 6,56 & 5,57 & 3,29 & 2,45 & 1,07 & 0,99 \\
\hline $\mathrm{T}^{3}$ & 4,37 & 1,35 & 6,12 & 3,26 & 6,53 & 5,14 & 6,19 & 5,08 & 2,74 & 1,86 & 0,71 & 0,63 \\
\hline $\mathrm{T} 4^{4}$ & 3,43 & 1,48 & 5,07 & 4,01 & 5,27 & 5,21 & 5,60 & 4,85 & 2,74 & 1,86 & 0,87 & 0,66 \\
\hline $\mathrm{T} 5^{5}$ & 4,85 & 1,63 & 6,66 & 5,01 & 7,52 & 5,41 & 7,45 & 5,60 & 4,76 & 3,14 & 2,34 & 1,25 \\
\hline
\end{tabular}

\footnotetext{
${ }^{\mathrm{T}} \mathrm{T} 1 \mathrm{~s} /$ pulverização com fungicidas e com duas inoculaçōes artificiais em intervalo de 10 dias;
}

${ }^{2} \mathrm{~T} 2$ : primeira pulverização no estádio $\mathrm{R}_{5}$ (pré - floração) e repetida uma única vez após 14 dias com duas inoculações artificiais em intervalo de 10 dias;

${ }^{3} \mathrm{~T}$ 3: pulverização iniciada no estádio $\mathrm{R}_{6}$ (floração) e repetida uma única vez após 14 dias com duas inoculações artificiais em intervalo de 10 dias;

${ }^{4} \mathrm{~T} 4$ : pulverização iniciada no estádio $\mathrm{R}_{5}$ (pré - floração) e continuada a cada 14 dias até as plantas terem atingido o estádio $R_{6}$ (floração) com duas inoculaçðes em intervalo de 10 dias;

${ }^{5} \mathrm{~T} 5$ : aplicações semanais de fungicida e sem inoculação;

${ }^{6}$ Valores do $L A I$ correspondente a média de 12 plantas;

${ }^{7}$ Valores do $L A I$ correspondente a média de seis leituras. 

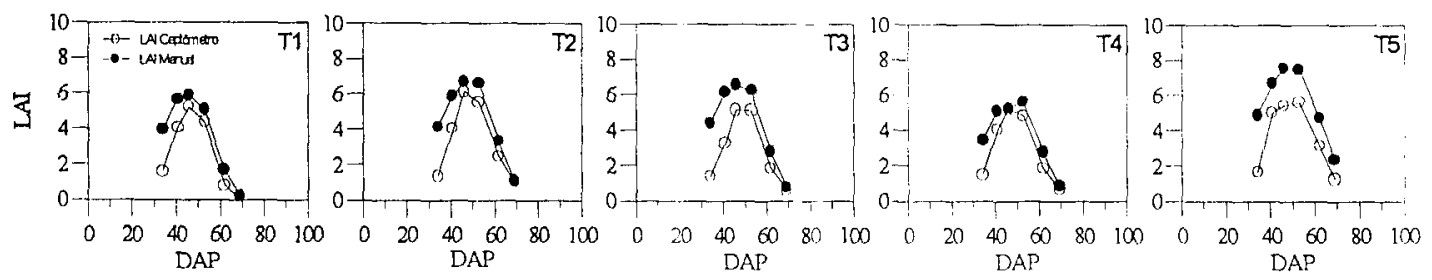

Figura 32 - Estimativas comparativas dos Índices de Área Foliar obtido através de medições diretas da área foliar ( $L A I$ Manual) e indiretamente com ceptômetro (LAI Ceptômetro) do experimento $\mathrm{C} 2$ (mancha angular trifenil hidróxido de estanho). Piracicaba, São Paulo, 1998 - 2000.

Foram realizadas oito avaliações com ceptômetro, isto é aos $38,46,52$, $67,73,81,88$ e 94 DAP no experimento C3 (ferrugem - oxycarboxin). Pode-se observar que o ceptômetro novamente subestimou os dados estimados diretamente (Tabela 12 e Figura 33).

De igual forma ao experimento $\mathrm{Cl}$ (ferrugem - oxycarboxin), os dados do $L A I$ obtidos com o ceptômetro do experimento $C 4$ (mancha angular - trifenil hidróxido de estanho) também ficaram subestimados, em pelo menos duas vezes. Neste experimento foram realizadas nove avaliações $(31,39,44,52,60,66,73,78$ e 85 DAP) (Tabela 13 e Figura 34). 
Tabela 12. Dados dos Índices de Área Foliar obtido de avaliações diretas da área foliar (LAI Manual) e indiretamente com o ceptômetro (LAI Ceptômetro) do experimento C3 (ferrugem - oxycarboxin). Piracicaba, São Paulo, 1998 2000 .

\begin{tabular}{|c|c|c|c|c|c|c|c|c|c|c|c|c|c|c|c|c|}
\hline \multicolumn{17}{|c|}{$L A I-\mathrm{C} 3$} \\
\hline & \multicolumn{2}{|c|}{$38 \mathrm{DAP}$} & \multicolumn{2}{|c|}{46 DAP } & \multicolumn{2}{|c|}{52 DAP } & \multicolumn{2}{|c|}{67 DAP } & \multicolumn{2}{|c|}{73 DAP } & \multicolumn{2}{|c|}{$81 \mathrm{DAP}$} & \multicolumn{2}{|c|}{$88 \mathrm{DAP}$} & \multicolumn{2}{|c|}{94 DAP } \\
\hline & $\mathrm{M}^{6}$ & $\mathrm{C}^{\prime}$ & $\mathbf{M}^{6}$ & $\mathrm{C}^{\prime}$ & $\mathbf{M}^{6}$ & $\mathrm{C}^{\prime}$ & $\mathrm{M}^{6}$ & $\mathrm{C}^{\prime}$ & $\mathbf{M}^{6}$ & $\mathrm{C}^{\prime}$ & $\mathbf{M}^{6}$ & $\mathrm{C}^{\prime}$ & $\mathbf{M}^{6}$ & $\mathrm{C}^{\prime}$ & $\mathrm{M}^{6}$ & $\mathrm{C}^{\prime}$ \\
\hline T1 & 0,57 & 0,45 & 1,15 & 0,98 & 2,18 & 1,14 & 3,43 & 2,35 & 4,0 & 2,11 & 4,2 & 1,75 & 3,78 & 2,15 & 1,0 & 0,60 \\
\hline $\mathrm{T} 2$ & 0,61 & 0,37 & 1,23 & 0,98 & 2,24 & 1,12 & 3,72 & 2,25 & 4,17 & 2,78 & 4,0 & 2,0 & 4,0 & 1,75 & 2,0 & 1,33 \\
\hline T3 & 0,68 & 0,45 & 1,23 & 0,78 & 2,49 & 1,20 & 3,78 & 2,25 & 4,09 & 3,05 & 3,89 & 2,05 & 3,47 & 1,98 & 0,51 & 0,35 \\
\hline $\mathrm{T} 4$ & 0,66 & 0,44 & 1,48 & 0,95 & 2,48 & 1,25 & 3,93 & 2,25 & 4,30 & 3,71 & 3,68 & 1,80 & 3,30 & 2,25 & 0,72 & 0,35 \\
\hline T5 & 0,57 & 0,35 & 1,29 & 0,75 & 2,25 & 1,20 & 3,36 & 2,05 & 4,09 & 1,65 & 3,82 & 1,32 & 3,25 & 1,0 & 1,19 & 0,65 \\
\hline
\end{tabular}

${ }^{1} \mathrm{~T} 1: \mathrm{s} /$ pulverização com fungicidas e com duas inoculações artificiais em intervalo de 10 dias;

${ }^{2} \mathrm{~T} 2$ : primeira pulverização no estádio $\mathrm{R}_{5}$ (pré - floração) e repetida uma única vez após 14 dias com duas inoculações artificiais em intervalo de 10 dias;

${ }^{3} \mathrm{~T} 3$ : pulverização iniciada no estádio $\mathrm{R}_{6}$ (floração) e repetida uma única vez após 14 dias com duas inoculações artificiais em intervalo de 10 dias;

${ }^{4} \mathrm{~T} 4$ : pulverização iniciada no estádio $\mathrm{R}_{5}$ (pré - floração) e continuada a cada 14 dias até as plantas terem atingido o estádio $\mathrm{R}_{6}$ (floração) com duas inoculações em intervalo de 10 dias;

${ }^{5}$ T5: aplicações semanais de fungicida e sem inoculação;

${ }^{6}$ Valores do $L A I$ correspondente a média de 12 plantas;

${ }^{7}$ Valores do LAI correspondente a média de duas medições, correspondendo a uma planta. 

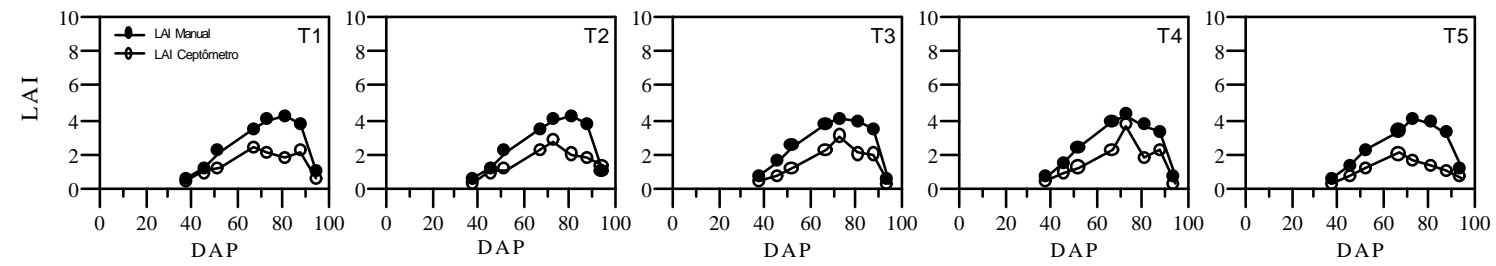

Figura 33 - Estimativas comparativas dos Índices de Área Foliar obtido através de medições diretas da área foliar (LAI Manual) e indiretamente com ceptômetro (LAI Ceptômetro) do experimento C3 (ferrugem - oxycarboxin). Piracicaba, São Paulo, 1998 - 2000.

Tabela 13. Dados dos Índices de Área Foliar obtido de avaliações diretas da área foliar (LAI Manual) e indiretamente com o ceptômetro (LAI Ceptômetro) do experimento C4 (mancha angular - trifenil hidróxido de estanho). Piracicaba, São Paulo, 1998 - 2000.

\begin{tabular}{|c|c|c|c|c|c|c|c|c|c|c|c|c|c|c|c|c|c|c|}
\hline \multicolumn{19}{|c|}{$L A I-C 4$} \\
\hline & \multicolumn{2}{|c|}{$31 \mathrm{DAP}$} & \multicolumn{2}{|c|}{39 DAP } & \multicolumn{2}{|c|}{44 DAP } & \multicolumn{2}{|c|}{52 DAP } & \multicolumn{2}{|c|}{60 DAP } & \multicolumn{2}{|c|}{66 DAP } & \multicolumn{2}{|c|}{73 DAP } & \multicolumn{2}{|c|}{78 DAP } & \multicolumn{2}{|c|}{85 DAP } \\
\hline & $M^{6}$ & $\mathrm{C}^{7}$ & $M^{6}$ & $\mathrm{C}^{7}$ & $M^{6}$ & $\mathrm{C}^{7}$ & $\mathrm{M}^{6}$ & $\mathrm{C}^{7}$ & $M^{6}$ & $\mathrm{C}^{7}$ & $M^{6}$ & $\mathrm{C}^{7}$ & $\mathrm{M}^{6}$ & $\mathrm{C}^{7}$ & $M^{6}$ & $\mathrm{C}^{7}$ & $\mathrm{M}^{6}$ & $\mathrm{C}^{7}$ \\
\hline $\mathrm{T} 1$ & 2,74 & 2,18 & 4,96 & 2,46 & 6,49 & 2,47 & 7,30 & 2,90 & 6,23 & 2,41 & 5,39 & 2,19 & 1,72 & 1,22 & 0,126 & 0,0 & 0,0 & 0,0 \\
\hline $\mathrm{T} 2$ & 2,24 & 2,45 & 4,81 & 2,78 & 5,99 & 3,27 & 7,34 & 3,32 & 6,52 & 3,09 & 6,45 & 2,49 & 4,04 & 1,97 & 1,79 & 1,0 & 0,18 & 0,0 \\
\hline $\mathrm{T} 3$ & 1,9 & 1,59 & 4,17 & 1,80 & 5,17 & 2,12 & 5,76 & 2,64 & 4,98 & 1,80 & 4,55 & 1,51 & 2,61 & 1,24 & 1,06 & 0,98 & 0,16 & 0,0 \\
\hline $\mathrm{T} 4$ & 2,11 & 1,80 & 4,25 & 2,04 & 5,13 & 2,40 & 6,51 & 2,48 & 5,77 & 2,29 & 5,33 & 2,10 & 2,90 & 1,47 & 0,72 & 0,66 & 0,04 & 0,0 \\
\hline $\mathrm{T} 5$ & 1,90 & 1,69 & 4,15 & 1,98 & 5,52 & 2,26 & 6,89 & 3,47 & 6,79 & 3,35 & 6,55 & 3,12 & 4,48 & 4,74 & 2,25 & 2,94 & 0,97 & 2,05 \\
\hline
\end{tabular}

\footnotetext{
${ }^{1}$ T1: s/ pulverização com fungicidas e com duas inoculações artificiais em intervalo de 10 dias;

${ }^{2} \mathrm{~T} 2$ : primeira pulverização no estádio $\mathrm{R}_{5}$ (pré - floração) e repetida uma única vez após 14 dias com duas inoculações artificiais em intervalo de 10 dias;

${ }^{3} \mathrm{~T} 3$ : pulverização iniciada no estádio $\mathrm{R}_{6}$ (floração) e repetida uma única vez após 14 dias com duas inoculações artificiais em intervalo de 10 dias;

${ }^{4} \mathrm{~T} 4$ : pulverização iniciada no estádio $\mathrm{R}_{5}$ (pré - floração) e continuada a cada 14 dias até as plantas terem atingido o estádio $\mathrm{R}_{6}$ (floração) com duas inoculações em intervalo de 10 dias;

${ }^{5}$ T5: aplicações semanais de fungicida e sem inoculação;

${ }^{6}$ Valores do $L A I$ correspondente a média de 12 plantas;

${ }^{7}$ Valores do LAI correspondente a média de duas medições, correspondendo a uma planta.
} 

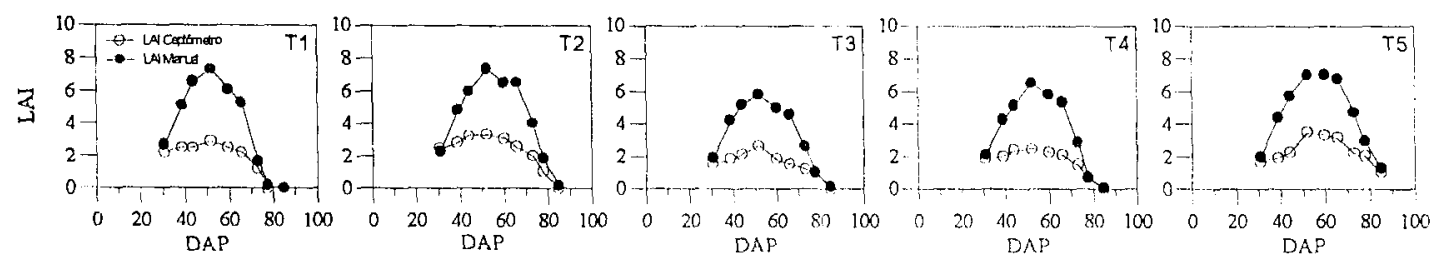

Figura 34 - Estimativas comparativas dos Índices de Área Foliar obtido através de medições diretas da área foliar (LAI Manual) e indiretamente com ceptômetro (LAI Ceptômetro) do experimento C4 (ferrugem oxycarboxin). Piracicaba, São Paulo, 1998 - 2000.

Apesar do ceptômetro ter subestimado todos os dados dos índices de área foliar obtidos, pode-se dizer que este equipamento conseguiu capturar as flutuações da área foliar ocorridas durante o ciclo da cultura.

Quando realizou-se regressão com passagem forçada através da origem entre os dados de $L A I$ obtidos diretamente através das medições da área foliar ( $L A I$ Manual) e os dados obtidos através das medições com o ceptômetro ( $L A I$ Ceptômetro), os coeficientes de determinação apresentados foram animadores. No experimento $C 1$ (ferrugem - oxycarboxin), a equação proposta foi: $L A I$ Ceptômetro=0,5697*LAI Manual e o coeficiente de determinação foi de 0,46 (Figura 33). Já no experimento $C 2$ (mancha angular - trifenil hidróxido de estanho), a equação proposta foi: $L A I$ Ceptômetro $=0,7249^{*} L A I$ Manual e o coeficiente de determinação foi de 0,80 (Figura 34). No experimento $C 3$ (ferrugem - oxycarboxin) o coeficiente de determinação foi maior que no experimento $\mathrm{Cl}$ (ferrugem - oxycarboxin), isto é 0,78 e a equação proposta foi: $L A I$ Ceptômetro=0,559* $L A I$ Manual (Figura 37). De igual forma ao experimento $\mathrm{C} 2$, o experimento $\mathrm{C} 4$ (mancha angular - trifenil hidróxido de estanho) também apresentou coeficiente de determinação elevado $(0,77)$ e a equação proposta foi: $L A I$ Ceptômetro=0,552*LAI Manual (Figura 38). 


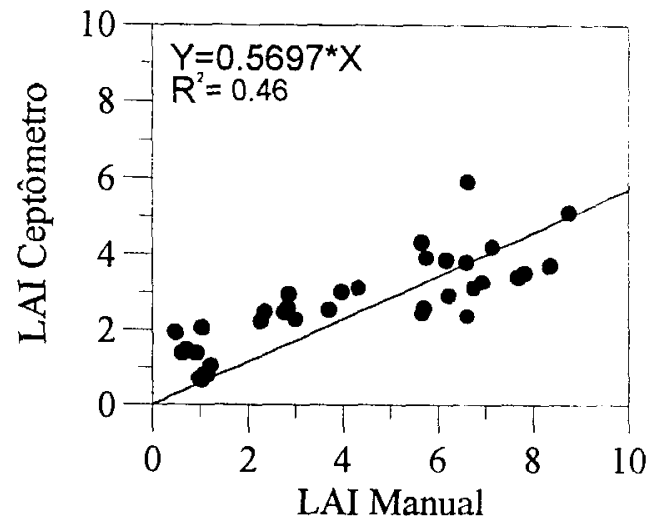

Figura 35 - Relação entre as estimativas comparativas dos Índices de Área Foliar obtido através de medições diretas da área foliar (LAI Manual) e indiretamente com ceptômetro ( $L A I$ Ceptômetro) do experimento Cl (ferrugem - oxycarboxin). Piracicaba, São Paulo, 1998 - 2000.

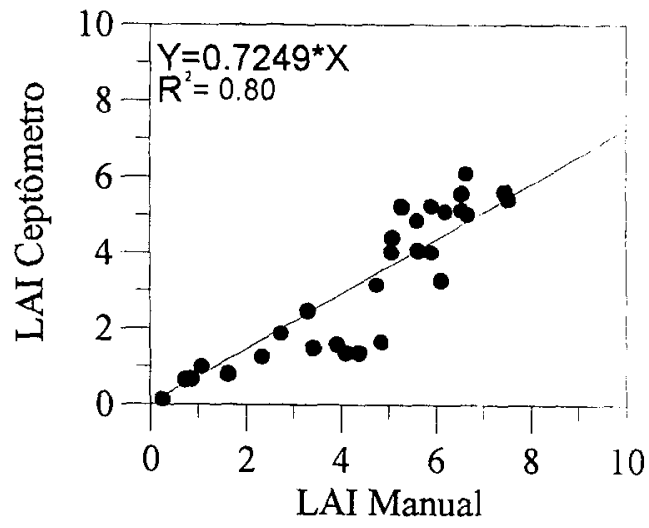

Figura 36 - Relação entre as estimativas comparativas dos Índices de Área Foliar obtido através de medições diretas da área foliar (LAI Manual) e indiretamente com ceptômetro ( $L A I$ Ceptômetro) do experimento C2 (mancha angular - trifenil hidróxido de estanho). Piracicaba, São Paulo, 1998 - 2000. 


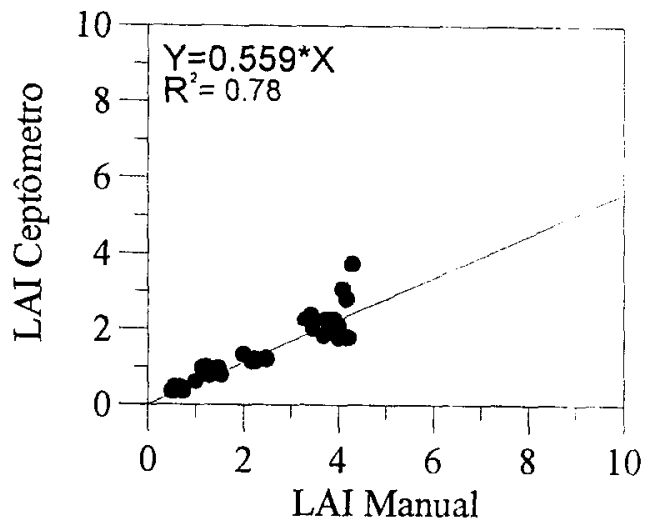

Figura 37 - Relação entre as estimativas comparativas dos Índices de Área Foliar obtido através de medições diretas da área foliar (LAI Manual) e indiretamente com ceptômetro ( $L A I$ Ceptômetro) do experimento C3 (ferrugem - oxycarboxin). Piracicaba, São Paulo, 1998 - 2000.

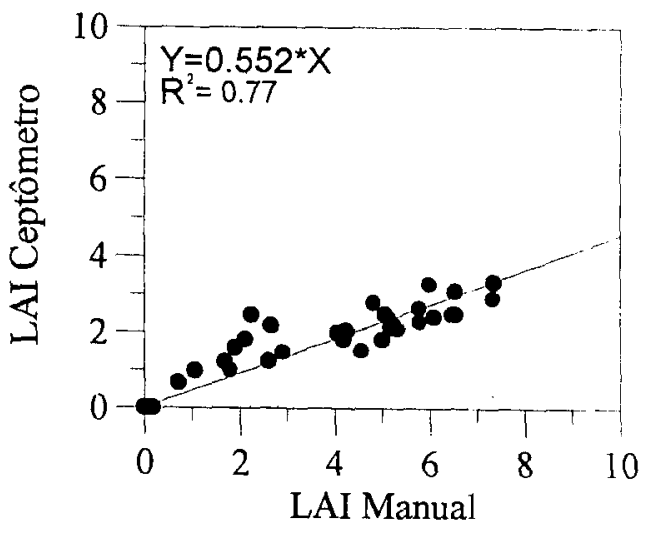

Figura 38 - Relação entre as estimativas comparativas dos Índices de Área Foliar obtido através de medições diretas da área foliar ( $L A I$ Manual) e indiretamente com ceptômetro (LAI Ceptômetro) do experimento C4 (mancha angular - trifenil hidróxido de estanho). Piracicaba, São Paulo, 1998 - 2000. 
A partir destes resultados, decidiu-se analisar conjuntamente as estimativas obtidas através das medições diretas da área foliar ( $L A I$ Manual) e indiretamente com ceptômetro (LAI Ceptômetro) dos quatro experimentos de forma a obter uma única equação que representasse todos os experimentos. O melhor ajuste foi obtido através de regressão linear com passagem forçada através da origem. A equação proposta foi $L A I$ Ceptômetro=0,5674*LAI Manual, com um coeficiente de determinação de 0,67 (Figura 39).

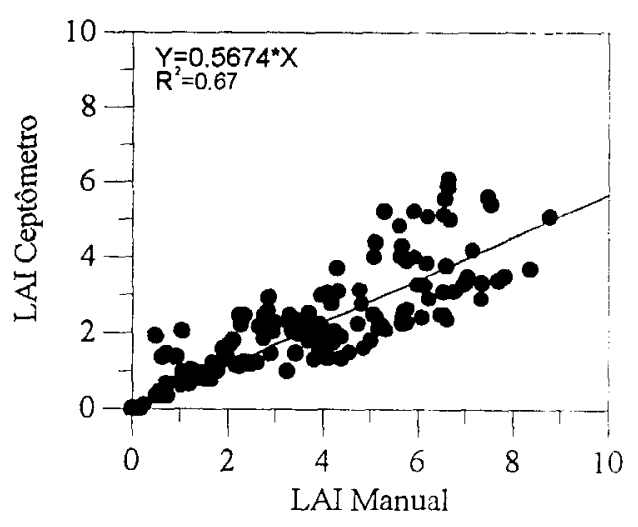

Figura 39 - Análise conjunta dos dados entre as estimativas obtidas através de medições diretas da área foliar ( $I_{\perp} A I$ Manual) e indiretamente com ceptômetro ( $L A I$ Ceptômetro) dos quatro experimentos. Piracicaba, São Paulo, 1998 - 2000.

Diante destes resultados faz-se necessário à discussão de alguns pontos, como a dificuldade na padronização da radiação solar incidente durante os momentos das avaliações, já que esta é extremamente variável nos diferentes horários do dia. Em geral os métodos indiretos de medições do $L A I$ são dependentes da arquitetura do dossel, isto é, a forma e a área de vários órgãos da planta (folhas, flores e ramos, etc.), ângulo de distribuição das folhas e ângulo de inclinação das folhas, portanto o horário 
da realização das leituras tem influência nas medições. Em dias sem nebulosidade, ao meio dia solar, observou-se que as folhas do feijoeiro assumiam o chamado heliotropismo, isto é orientação preferencial das folhas em direção aos raios solares, especialmente em dias ensolarados. Este fenômeno proporcionava ao equipamento a possibilidade de capturar uma maior interceptação de luz através de todas as camadas do dossel e conseqüentemente proporcionava valores mais elevados de LAI. A desvantagem é que este fenômeno só foi observado em apenas um curto período do dia (ao redor do meio dia solar) e apenas em dias com alta intensidade solar.

Outro fator de interferência nas leituras foi a passagem constante de nuvens sobre o sol nos momentos das avaliações, o que provocava a redução da radiação incidente e conseqüentemente a redução das leituras do LAI. Barradas et al. (1999), estudando a orientação e distribuição foliar em Phaseolus vulgaris, observou que a maior proporção de inclinação das folhas foi ao redor de $30-40^{\circ}$ em dias nublados e entre $40-50^{\circ}$ em dias ensolarados. Diante desta dificuldade procurou-se executar as medições sempre que a leitura da radiação incidente ao sol estava entre $1200-1400$.

Vale ressaltar que nem sempre no momento das leituras essas características estavam presentes, o que pode ter provocado a subestimação dos valores de $L A I$ obtido com o equipamento.

Um fator extremamente importante a ser lembrado é que as medições do LAI obtidas diretamente (LAI Manual) e indiretamente (LAI Ceptômetro) não foram obtidas no mesmo local (sub-parcelas $1 \mathrm{~S}$ e $2 \mathrm{~S}$, respectivamente), portanto as plantas possivelmente não apresentavam a mesma área foliar o que pode ter provocado a subestimação dos valores do índice de área foliar obtido com o ceptômetro. Quando Welles \& Norman (1991) estimaram o LAI de soja e trigo utilizando um ceptômetro (LAI-2000), concluíram que o equipamento subestimou em pelo menos $15 \%$ as medições quando estas foram comparadas com as medições diretas.

Peressotti et al. (1999), estudando os coeficientes de extinção, sob diferentes métodos, em trigo, girassol e milho, observaram que os valores de $k$ foram altamente variáveis dependendo da espécie, do momento do dia e da posição foliar das 
culturas. Estes autores demonstraram que o modelo baseado na Lei de Beer (Monteith, 1990) simplifica o que acontece realmente no complexo do dossel e que mudanças na elevação solar, geometria foliar e o movimento foliar influenciam significativamente os valores de $k$. Bosch Serra et al. (2000) também observaram em seus estudos com Allium cepa que o coeficiente de extinção $(k)$ não foi constante durante todo o período de crescimento vegetativo desta cultura. Neste trabalho o coeficiente de extinção utilizado durante todas as avaliações com o ceptômetro foi o mesmo, isto é, 0,7 (Miglioranza, 1992).

Em programas de manejo de doenças, a utilização de modelos integrais apresenta algumas desvantagens, a principal é a necessidade de serem realizadas no mínimo duas avaliações espaçadas no tempo para poderem ser utilizadas em processo de tomada de decisão. Neste contexto, pode-se dizer que a utilização de equipamentos como o ceptômetro parece simplificar muito o processo e mesmo minimizar tal desvantagem já que em apenas alguns minutos e sem utilizar nenhum cálculo, os valores de índice de área foliar (LAI) são obtidos. Basta, porém, adicionar a estas estimativas a avaliação de porcentagem de severidade das doenças, utilizando-se de escalas diagramáticas, nas parcelas controle (sensu Lopes et al. 1994) e com isso calcular facilmente o índice de área foliar sadio (HLAI).

Resta, pois, a validação e o refinamento do modelo, já que este pode com certeza ser muito útil na quantificação de danos para implementação de um sistema de manejo de doenças do feijoeiro baseado no limiar de dano econômico. 


\section{CONCLUSÕES}

De acordo com a proposta inicial do trabalho e a partir dos resultados obtidos, pode-se concluir que:

- A AUDPC obtida através dos valores de severidade da ferrugem e da mancha angular do feijoeiro, não apresentou boa correlação com a produção;

- As funções de dano para a ferrugem e a mancha angular do feijoeiro foram melhor estabelecidas utilizando-se das variáveis $H A D$ e $H A A$ quando estas foram correlacionadas com a produção (gramas por planta), embora não tenha havido uma consistência entre as diferentes épocas de plantio;

- O limiar de dano econômico da ferrugem e da mancha angular do feijoeiro foi estimado em 1/27 de HLAI (ferrugem); 1/32 de HLAI (mancha angular); 1/2 de HRI (ferrugem) e 0,67 de HRI (mancha angular), sendo que este limiar foi atingido para 75\% dos experimentos entre os estádios R5-R6;

As medições obtidas com o ceptômetro apresentaram sensibilidade suficiente para captar as variações no índice de área foliar sadio e portanto podem ser integradas em sistemas de manejo da ferrugem e da mancha angular do feijoeiro; 


\section{REFERÊNCIAS BIBLIOGRÁFICAS}

ACCUPar. Light interception crop \& timber analysis: operator's manual, s.d. 120p. ACOCK, M.C.; DAUGHTRY, C.S.T.; BEINHART, G.; HIRSCHMANN, E.;

ACOCK, B. Estimating leaf mass from light interception measurements on isolated plants of Erythroxylum species. Agronomy Journal, v.86, p.570-574, 1994.

AMORIM, L.; BERGAMIN FILHO, A. Avaliação de doenças com utilização de escalas diagramáticas. Summa Phytopathologica, v.17, n.l, p.57-67, 1991.

AMORIM, L.; BERGAMIN FILHO, A.; GODOY, C. V.; IAMAUTI, M. T.; NUNES, W. M.; CARNEIRO, S. M. T. P. G. Avaliação de danos na cultura do feijoeiro. Summa Phytopathologica, v.21, p.82-84, 1995.

AQUINO, V. M.; SHOKES, F. M.; BERGER, R. D.; GORBET, D. W.; KUCHARAK. Relationships among late leafspot, healthy leaf area duration, canopy reflectance, and pod yield of peanut. Phytopathology, v.82, p.546-552, 1992.

ARMBRUST, D.V. Rapid measurement of crop canopy cover. Agronomy Journal, v.82, n.11, p. 1170-1171, 1990.

BARRADAS, V. L.; JONES, H. G.; CLARK, J. A. Leaf orientation and distribution in a Phaseolus vulgaris L. crop and their relation to light microclimate.

International Journal of Biometeorology, v.43, n. 2, p.64-70, 1999.

BARROS, B. C.; CASTRO, J.L. Eficiência de fungicidas no controle da manchaangular do feijoeiro comum. In: DIA DE CAMPO DE FEIJÃO, 16., Embrapa, Passo Fundo: CNPT, 2000, p.17-20. 
BASSANEZI, R.B. Interações entre o mosaico-em-desenho do feijoeiro e duas doenças fúngicas, ferrugem e mancha angular, em plantas de feijoeiro. Piracicaba, 1995. 127p. Dissertação (Mestrado) - Escola Superior de Agricultura "Luiz de Queiroz”, Universidade de São Paulo.

BASTIAANS, L.; RABBINGE, R.; ZADOKS, J.C. Understanding and modeling leaf blast effects on crop physiology and yield. In: ZEIGGLER, R.S.; LEONG, S.A.; TENG, P.S. (Ed.) Rice blast disease. Wallingford: CAB. International, 1994. p. 357-380.

BEEBE, S.E.; PATOR-CORRALES, M. Breeding fo disease resistance. In: SCHOONHOVEN, A. van; VOYSEST, O. (Ed.) Common beans: research for crop improvement. Wallingford: CAB International, 1991. cap.10, p.561-618.

BERGAMIN FILHO, A. Avaliação de danos e perdas. In: BERGAMIN FILHO, A.; KIMATI, H.; AMORIM, L. (Ed.) Manual de fitopatologia: princípios e conceitos. 3. ed. São Paulo: Agronômica Ceres, 1995. v.1, cap. 33, p. 372-690.

BERGAMIN FILHO, A.; AMORIM, L. Doenças de plantas tropicais: epidemiologia e controle. São Paulo: Agronômica Ceres, 1996. 299p.

BERGAMIN FILHO, A.; LOPES, D. B.; AMORIM, L.; GODOY, C. V.; BERGER, R. D. Avaliação de danos causados por doenças de plantas. Revisão Anual de Patologia de Plantas,v.3, p.133-184, 1995.

BERGAMIN FILHO, A.; CARNEIRO, S. M. T. P. G.; GODOY, C. V.; AMORIM, L., BERGER, R. D.; HAU, B. Angular leaf spot of Phaseolus beans: relationships between disease, healthy leaf area, and yield. Phytopathology, v.87, p.506-515, 1997.

BERGER, R. D. Measuring disease intensity. Biological and Cultural Tests, v.3, p. 1-4, 1988.

BIANCHINI, A.; MARINGONI, A. C.; CARNEIRO, S. M. T. P. G. Doenças do feijoeiro. In: KIMATI, H.; AMORIM, L.; BERGAMIN FILHO, A.; CAMARGO, L.E.A.; REZENDE, J.A.M. Manual de fitopatologia. São Paulo: Editora Ceres, 1997. v.2, p.376-399. 
BIANCHINI, A.; MENEZES, J. R.; MARINGONI, A. C. Doenças e seu controle. In: INSTITUTO AGRONÔMICO DO PARANÁ. O feijão no Paraná. Londrina, 1989. p. 189-216. (IAPAR. Circular, 63).

BISSONNETTE, S. M.; D'ARCY, C. J.; PERDERSEN, W.L. Yield loss in two spring oat cultivars due to Puccinia coronata f. sp. avenae in the presence or absence of barley dwarf virus. Phytopathology, v.84, 1994, p. 363-367.

BOOTE, K.J.; JONES, J.W.; MISHOE, J.W.; BERGER, R.D. Coupling pests to crop growth simulators to predict yield reductions. Phytopathology, v.73, p.1581$1587,1983$.

BOSCH SERRA, A. D.; CASANOVA, D.; CHALlA, H.; MONTEIRO, A. A.; HEUVELINK, E.; AGUIAR PINTO, A. Estimation of onion (Allium cepa, L.) biomass and light interception from reflectance measurements at field level. Acta Horticulturae, n.519, p.53-59, 2000.

BOURGEOIS, G.; BOOTE, K. J. Leaflet and canopy photosynthesis of peanut affected by late leafspot. Agronomy Journal, v.84, p.359-366, 1992.

BRENES, B.M. Estimativa de perdas no rendimento de feijoeiro-comum (Phaseolus vulgaris L.) causadas pela mancha angular (Isariopsis griseola Sacc.). Viçosa, 1983. 60p. Dissertação (Mestrado) - Universidade Federal de Viçosa.

BROSCIOUS, S. C.; PATAKY, J. K.; KIRBY, H. W. Quantitative relationships between yield and foliar diseases of alfafa. Phytopathology, v.77, p.887-892, 1987.

BULISANI, E. A. Principais probelmas da cultura do feijoeiro irrigado. In: FANCELLI, A. L (Coord.) Feijão irrigado. Piracicaba: FEALQ, 1990. p.25-30.

CAMPBELL, C. L.; L. V. MADDEN. Introduction to plant disease epidemiology. New York: John Wiley, 1990. 123p.

CAMPBELL, G. S.; NORMAN, J. M. The description and measurement of plant canopy structure. In: RUSSEL, G.; MARSHALL, B.; FARVIS, P. G. (Ed.) Plant canopies: their growth, form, and function. Cambridge: Cambridge University Press, 1989. p. 1-19. 
CAMPOS, J. A.; FUCIKOVSKY, L. Z. Estudio de algunas caracteristicas de Isaripsis griseola Sacc. Agente causal de la mancha angular del frijol. Agrociência, v.39, p.41-48, 1980.

CANTERI, M. G. Uso de medidas de área foliar sadia e refletância no manejo da mancha angular do feijoeiro. Piracicaba, 1998. 83p. Tese (Doutorado) - Escola Superior de Agricultura “Luiz de Queiroz”, Universidade de São Paulo.

CANTERI, M. G.; GIGLIOTI, E. A. Software para seleção e treinamento de avaliadores de severidade de doenças em cana de açúcar. Publicação UEPG. Ciências Exatas e da Terra, v.2, p.57-69, 1996.

CANTERI, M. G.; DALlA PRIA, M.; TESSMANN, D. J.; MOLIN, R. Efeito de épocas de semeadura sobre níveis de doenças do feijoeiro sob condições naturais de infecção na região dos Campos Gerais do Paraná. Summa Phytopathologica, v.23, n.1, p.54, 1997.

CANTERI, M. G.; DALlA PRIA, M.; SCHIEBELBEIN, L. M.; SILVA, O. C.; AMORIM, L.; BERGAMIN FILHO, A. Relações entre área foliar sadia, produtividade, refletância e severidade da mancha angular do feijoeiro. Fitopatologia Brasileira, v. 23, n. 4, p.498-501, 1998.

CARDONA-ALVAREZ, C.; WALKER, J. C. Angular leaf spot of bean. Phytopathology, v.46, n.4, p.610-615, 1956.

CARNEIRO, S. M. T. P. G. Quantificação de danos causados por Phaeoisariopsis griseola em feijoeiro (Phaseolus vulgaris) no município de Londrina-PR. Piracicaba, 1995. 102p. Dissertação (Mestrado) - Escola Superior de Agricultura "Luiz de Queiroz", Universidade de São Paulo.

CARNEIRO, S. M. T. P. G. Efeito da infecção de Phaeoisariopsis griseola e Colletotrichum lindemuthianum nos componentes de produção e nas variáveis de área foliar do feijoeiro. Piracicaba, 1999. 89p. Tese (Doutorado) - Escola Superior de Agricultura “Luiz de Queiroz”, Universidade de São Paulo. 
CARNEIRO, S. M. T. P. G.; AMORIM, L.; BERGAMIN FILHO, A. Avaliação de dano provocado pela mancha angular em feijoeiro: relação entre severidade, área foliar e componentes de produção. Fitopatologia Brasileira, v.22, p.427-431, 1997.

CARVER, T. L.W.; GRIFFITHS, E. Effects of barley mildew on green leaf area and grain yield in field and greenhouse experiments. Annals of Applied Biology, v.101, p. 561-572, 1982.

CASTRO, J.L.; DUDIENAS, C.; ITO, M.F.; IGUE, T. Eficiência de fungicidas no controle das doenças do feijoeiro (Phaseolus vulgaris L.) Summa Phytopathologica, v.15, p.145-155, 1989.

CHARLES-EDWARDS, D. A. Physiological determinants of crop growth. Sidney: Academic Press, 1982.89 p.

CHASON, J. W.; BALDOCCHI, D. D.; HUSTON, M. A. A comparasion of direct and indirect methods for estimating forest canopy leaf area. Agricultural and Forest Metereology, v.57, p.107-108, 1991.

CHEN, J. M.; RICH, P. M.; GOWER, S. T.; NORMAN, J. M.; PLUMMER, S. Leaf area index of boreal forests: theory, techniques, and measurements, Journal of Geophysical Research Atmospheres, v. 102, p.29429-29443, 1997.

CHIANG, H. C.; WALLEN, V. R. Detection and assessment of crop diseases and insect infestations by aerial photography. FAO. Crop Loss Assesment Methods, v.2, p.7/2-7/12, 1977. Supplement.

CHIARAPPA, L. (Ed.). Crop loss assessment methods. Farnham Royal: CAB, 1971. $123 p$.

CORREA, F. J.; SAETTLER, A. W. Pathogenic variation in Isariopsis griseola, cause of angular leaf spot of bean. Phytopathology, v.76, n.10, p.1141-1141, 1986.

COSTA, A. S. Investigações sobre moléstias do feijoeiro no Brasil. In: SIMPÓSIO BRASILEIRO DO FEIJÃO 1., Campinas, 1971. Anais. Viçosa: Universidade Federal de Viçosa, 1972. p.305-311. 
DAAMEN, R. A.; JORRISTSMA, I. T. M. Effects of powdery mildew and weather on winter wheat yields. Netherlands Journal of Plant Pathology, v. 96, p. 3546, 1982.

DALLA PRIA, M. Quantificação de parâmetros monocíclicos da antracnose (Colletotrichum lindemuthianum) e da mancha angular (Phaeoisariopsis griseola) do feijoeiro. Piracicaba, 1997. 82p. Dissertação (Mestrado) - Escola Superior de Agricultura "Luiz de Queiroz", Universidade de São Paulo.

DE WILT, C. T. Photosyntesis of leaf canopies. Wageningen, 1965. 663 p.

DIAZ, C. G. Avaliação de danos causados por Xanthomonas axonopodis pv. phaseoli em feijoeiro (Phaseolus vulgaris L.) Piracicaba, 2000. 78p. Tese (Doutorado) Escola Superior de Agricultura "Luiz de Queiroz”, Universidade de São Paulo.

ELLIS, M. A.; GALVEZ, G. E.; SINCLAIR, J. B. Effecto de tres fungicidas sobre la germinacioón de semilla infectada de frijol (Phaseolus vulgaris, L.) Turrialba, v.26, p.399-402, 1976.

FANCELLI, A. L. Cultura do feijão: cursos de reciclagem em agricultura. Piracicaba: FEALQ, 1987. 138p.

FAO. Report of the first session of the FAO panel of experts on integrated pest control. Rome, 1968. 19p.

FERRANDINO, F. J.; ELMER, W. H. Reduction in tomato yield due to septoria leaf spot. Plant Disease, v.76, p.208-211, 1992.

FERRAZ, S. La mancha foliar angular. In: SCWARTZ, H. P.; GÁLVEZ, G. E. (Ed.)

Problemas de producción del frijól: enfermedades, insectos, limitaciones edáficas y climáticas de Phaseolus vulgaris. Cali: CIAT, 1980. p.55-64.

GALLAGHER, J. N.; BISCOE, P. V. Radiation absorption, growth and yield of cereals. Journal of Agricultural Sciences, v.91, p.47-60, 1978.

GAUNT, R. E. Physiological basis of yield loss. In: STAKMAN COMMEMORATIVE SYMPOSIUM ON CROP LOSS ASSESSMENT, St. Paul, 1981. University of Minnesota, p.98-111.

GAUNT, R. E. Meassurement of disease and pathogens. In: TENG, P. S. Crop loss assessment and pest management. St. Paul: APS Press, 1987. cap. 2, p.6-18. 
GAUNT, R. E. New technologies in disease measurement and yield loss appraisal. Canadian Journal of Plant Pathology, v.17, p.185-189, 1995a.

GAUNT, R. E. The relationship between plant disease severity and yield. Annual Review of Phytopathology, v.33, p.119-144, 1995 b.

GAUNT, R. E.; BRYSON, R. J.; WALTERS, R. D.; SCHOELES, J. D.; BRYSON, R. J.; PAUL, N. D.; McROBERTS, N. (Ed.). Physiological responses of plants to pathogens. Association of Applied Biologists, Wellesbourne, 1995. p.1-7.

GIANASI, L. Antracnose do feijoeiro: quantificação de danos e efeito do trifenil acetato de estanho no crescimento do hospedeiro e no progresso da doença. Piracicaba, 1999, 120p. Tese (Doutorado) - Escola Superior de Agricultura "Luiz de Queiroz”, Universidade de São Paulo.

GODOY, C. V. Avaliação de danos causados pela mancha angular do feijoeiro. Piracicaba, 1995. 72p. Dissertação (Mestrado), Escola Superior de Agricultura "Luiz de Queiroz", Universidade de São Paulo.

GODOY, C. V.; CARNEIRO, S. M. T. P. G.; IAMAUTI, M. T.; DALLA PRIA, M.; AMORIM, L.; BERGAMIN FILHO, A.; BERGER, R. D. Diagramatic scales for foliar diseases of beans: development and validation. Zeitschrift für Pflanzenkrankheiten und Pflanzenschutz, v.104, p.336-345, 1997.

GOULART, A. C .P. Eficiência de fungicidas no controle de doenças foliares do feijoeiro. Fitopatologia Brasileira, v.15, p.86-88, 1990.

GRIFFITH, E. Foliar diseases: the damage caused and its effects on yield. In: WOOD, R.K.S.; JELLIS, G.J. Plant diseases: infection, damage and loss. Oxford: Blackwell Scientific, 1984. p.149-159.

HALL, R. Compendium of bean diseases. St. Paul: American Phytopathological Society, 1991.73p.

HATFIELD, D. L. Remote detection of crop stress: application to plant pathology. Phytopathology, v.80, p.37-39, 1990.

HAU, B.; KRANZ, J.; DENGEL, H.J.; HAMELINK, J. On the development of loss assessment in the tropics. In TENG, P.S.; KRUPA, S. V. (Ed.) Crop loss assessment. St. Paul: University of Minnesota, 1980. p.254-261. 
HUGHES, G.; KEATINGE, J. D. H.; SCOTT, S. P. Piegeon pea as a dry season crop in Trinidad, West Indies. II Interception and utilization of solar radiation. Tropical Agriculture, v. 58, p.191-199, 1981.

IAMAUTI, M. T. Avaliação de danos causados por Uromyces appendiculatus no feijoeiro. Piracicaba, 1995. 81p. Tese (Doutorado) - Escola Superior de Agricultura "Luiz de Queiroz", Universidade de São Paulo.

ISSA, E.; SINIGAGLIA, C.; OLIVEIRA, D. A. Controle químico da "mancha angular"da folha, Isariopsis griseola Sacc., do feijoeiro, Phaseolus vulgaris L. O Biológico, v.48, p.299-303, 1982.

ITO, M. F.; BERGAMIN FILHO, A.; YUKI, V. A. Ação fungicida do inseticida cartap sobre a ferrugem do feijoeiro. Fitopatologia Brasileira, v.21, p.44-49, 1996.

ITO, M. F.; CASTRO, J. L.; BERGAMIN FILHO, A. Efeito do inseticida cartap sobre a mancha angular do feijoeiro. Fitopatologia Brasileira, v.19, p.288-289, 1994. Suplemento.

JACKSON, R. D. Remote sensing of biotic and abiotic plant stress. Annual Review of Phytopathology, v.24, p.265-287, 1986.

JAMES, W. C. Assessment of plant disease and losses. Annual Review of Phytopathology, v.12, p.27-48, 1974.

JOHNSON, K. B. Assessing multiple pest population and their effects on crop yield. In: TENG, P. S. (Ed.) Crop loss assessment in rice. Manila: International Rice Research Institute, 1990, p.203-214.

JOHNSON, K. B. Evaluation of a mechanistic model that describes potato losses caused by multiple pests. Phytopathology, v.82, p.363-369, 1992.

JOHNSON, K. B.; TENG, P. S. Coupling a disease progress model for early blight to a model of potato growth. Phytopathology, v.77, p.1495-1497, 1990.

JOHNSON, K. B.; JOHNSON, S. B.; TENG, P. S. Development of a simple potato growth model for use in crop-pest management. Agricultural Systems, v.19, p.189-209, 1986. 
KIMATI, H. Doenças do feijoeiro. In: GALLI, F. (Ed.) Manual de fitopatologia. São Paulo: Ed. Ceres, 1980. v.2, p.297-318.

KIMATI, H.; GIMENES - FERNANDES, N.; SOAVE, J.; KUROZAWA, C.; BRIGNANI NETO, F.; BETTIOL, W. Guia de fungicidas agrícolas: recomendações por cultura. 2. ed. Jaboticabal: Grupo Paulista de Fitopatologia, 1997. v. 1,225 p.

KRANZ, J. Measuring plant disease. In: KRANZ, J. ; ROTEM, J. Experimental techniques in plant disease epidemiology. Heidelberg: Springer, 1988. cap. 3, p.35-50.

KRANZ, J.; JÖRG, E. The synecological approach in plant disease epidemiology. Review of Tropical Plant Pathology, v.6, p.27-38, 1989.

KULIK, M. M. Symptomatology and epidemiology of several green bean diseases incited by seed born fungi. Seed Science and Technology, v.12, p.841-850, 1984.

LANG, A. R. G. Simplified estimate of leaf area index from transmittance of the sun's beam. Agricultural andForest Meteorology, v.41, p.179-186, 1987.

LARSSON, M.; GERHARDSON, B. Disease progression and yield losses from root diseases caused by soilborne pathogens os spinack. Phytopathology, v. 82, p.403- 406, 1992.

LIM, L. G.; GAUNT, R. E. Leaf area as factor in disease assessment. Journal of Agricultural Science, v.97, p.481-483, 1981.

LIM, S. M. Brown spot severity and yield reduction in soybean. Phytopathology, v.70, p.974-977, 1980.

LINDGREN, D. T.; ESKRIDGE, K. M.; STEADMAN, J. R. A model for dry bean yield loss due to rust. Hort Technology, v.5, p.35-37,1995.

LOPES, D. B.; BERGER, R. D.; BERGAMIN FILHO, A. Absorção da área foliar sadia $(H A A)$ : uma nova abordagem para a quantificação de dano e para o manejo integrado de doenças. Summa Phytopathologica, v.20, n.3/4, p.134-151, 1994.

MADDEN, L. V. Measuring and modeling crop losses at field level. Phytopathology, v.73, p.1591-1596, 1983. 
MADDEN, L. V.; NUTTER Jr., F. W. Modeling crop losses et the field scale. Canadian Journal of Plant Pathology, v.17, p.124-137, 1995.

MADEIRA, A. C.; CLARK, J. A.; ROSSAL, S. Growth, light interception and disease in field bean (Vicia faba): the effect of late infection by Ascochyta fabae. Annals of Applied Biology, v.112, p.585-595, 1988.

MANGOLD, J. R. Seaonal abundance of defoliating lepidopterous larvae and predaceous arthropods and simulated defoliator damage to peanuts. Gainesville, 1979. 124p. Thesis (Ph.D.) - University of Florida.

MARCOS FILHO, J.; CÍCERO, S. M.; SILVA, W. R. Avaliação da qualidade das sementes. Piracicaba: FEALQ, 1987. 230p.

MARTENS, S. N.; USTIN, S. L.; ROUSSEAU, R. A. Potential of using field spectroscopy during early growth for ranking biomass in cereal breeding trials, Annals of Applied Biology, v.110, p.525-528, 1988.

MARTINS, M. C. Quantificação dos parâmetros monocíclicos e controle químico da ferrugem do pessegueiro. Piracicaba, 1994. 68p. Dissertação (Mestrado) - Escola Superior de Agricultura "Luiz de Queiroz", Universidade de São Paulo.

MENDES, B. M. J.; BERGAMIN FILHO, A. Influence of temperature, wetness duration, and leaf type on the quantification of monocyclic parameters of bean rust. Journal of Phytophatology, v.126, p.183-189, 1989.

MENEZES, J. R. Manejo integrado das doenças do feijoeiro irrigado. In: SEMINÁRIO SOBRE PRAGAS, DOENÇAS E PLANTAS DANINHAS DO FEIJOEIRO, Piracicaba: 1994.

MICHAELS, T. E. The bean plant. In: HALL, R. (Ed) Compendium of bean disease. St. Paul: The American Phytopatological Society, 1994. p. 1-4.

MIGLIORANZA, E. Modelo matemático-fisiológico para simular o crescimento e a produtividade da cultura do feijão (Phaseolus vulgaris, L.). Viçosa, 1992. 75p. Dissertação (Mestrado) - Universidade Federal de Viçosa.

MILLER, J. B. A formula for average foliage density. Australian Journal of Botany, v.15, p.141-144, 1967. 
MONTEITH, J. L. Does light limit crop production? In: JOHNSON, C. B. (Ed.) physiological processes limiting plant productivity. London: Butterworths, 1981. p.23-28.

MONTEITH, J. L.; ELSTON, J. Performance and productivity in the field. In: DALE, J. E.; MILTHORPE, F. L. (Ed.) The growth and functioning of leaves. Cambridge: Cambridge University Press,1983. p.499-518.

MONTEITH, J. L.; UNSWORTH, M. Principles of environmental physics. New York:Arnold, 1990. $130 \mathrm{p}$.

MORSE, S.; BUHLER, W. Integrated pest management: Ideals and realities in developing countries. London: Lynne Rienner, 1997. 170p.

MUNFORD, J. D.; NORTON, G. A. Economics of decision making in pest management. Annual Review of Entomology, v.29, p.157-174, 1984.

NATIONAL ACADEMY OF SCIENCES. Insect pest management and control. Washington, 1969.73p.

NICKLE, D. A. The peanut agroecosystem in Central Florida: economic thresholds for defoliating noctuids (Lepidoptera, Noctuidae); associated parasites; hyperparasites of the Apanteles complex (Hymenoptera, Braconidae. Gainesville, 1977 123p. Thesis (Ph.D) - Universisty of Florida

NILSSON, H. E. Application of remote sensing and image analysis at macroscopic and microscopic levels in plant pathology. In: TENG, P. S.; KRUPA, S. V. (Ed.). Crop loss assesment. St Paul: University of Minnesota, 1980. p.77-84.

NORMAN, J. M.; CAMPBELL, G. S. Canopy structure. In: PEARCY, J.R.; EHLERINGER, H. A; MOONEY, H. A; RUNDEL, P. W. (Ed.) Plant physiological ecology: field methods and instrumentation. London: Chapman and Hall. 1989. p.301-325.

NUNES, W. M. C. Avaliação dos danos causados pela antracnose (Colletotrichum lindemunthianum (Sacc. \& Magn.) Scribner) do feijoeiro (Phaseolus vulgaris, L.). Piracicaba, 1994. 74 p. Dissertação (Mestrado) - Escola Superior de Agricultura “Luiz de Queiroz”, Universidade de São Paulo. 
NUNES, W. M. C.; BERGAMIN FILHO, A. Avaliação de danos causados pela antracnose (Colletotrichum lindemuthianum) do feijoeiro. Fitopatologia Brasileira, v.21, n.4, p.436-442, 1996.

NUTTER JR., F. W.; LITTRELL, R. H. Relationships between defoliation, canopy reflectance and pod yield in the peanut-late leafspot pathosystem. Crop Protection, v.15, p135-142, 1996.

OIJEN, M. van. Photosynthesis is not impaired in healthy tissue of blighted potato plants. Netherlands Journal of Plant Pathology, v.96, p.55-63, 1990.

OLIVEIRA, S. H. F.; BARROS, B. C.; CASTRO, J. L. Avaliação do efeito de fungicidas no controle de doenças da parte aérea e na qulidade das sementes de feijoeiro. Summa Phytopathologica, v. 18, p.1530, 1988.

OPLUSTILOVA, M.; DVORAK, V.; MAREK, M. V.; VYSKOT, I. Leaf area index, its significance and methods of estimation. Lesnictvi UZPI Czech Republic, V.41, n. 8, p. 353-358, 1995.

PATAKY, J. K.; BEUTE, M. K.; WYNNE, J. C.; CARLSON, G. A. A critical point yield model for Cylindrocladium black rot of peanut. Phytopathology, v.73, p.1559-1563, 1983.

PAVELEY, N. D.; LOCKLEY, K. D.; SYLVESTER-BRADLEY, R.; THOMAS, J. Determinants of fungicide spray decisions for wheat. Pesticide Science, v.49, p.379-388, 1997.

PERESSOTTI, A.; MARCHIOL, L.; ZERBI, G. Evaluation of light extinction coefficients by different methods in canopies of wheat, sunflower, and maize. Italian Journal of Agronomy, v.3, n. 1, 41-48, 1999.

PIXLEY, K. V. Physiological and epidemiological characteristics of leaf spot resistance in four peanut genotypes. Gainesville, 1995. 89p. Dissertation (M.S.) University of Florida.

PIXLEY, K. V.; BOOTE, K. J.; SHOKES, F. M.; GORBET, D. W. Disease progression and leaf area dynamics of four peanut genotypes differing in resistance and late leaf spot. Crop Science, v.30, p.789-796, 1990. 
POMPEU, A. S.; BUliSANI, E. A.; GALlO, P. B.; CASTRO, J. L. DE; BORTOLETTO, N.; SAKAI, M.; LELIS, L. G. L.; DE CASTRO, J. L. Estimativa da capacidade produtiva de linhagens de cultivares de feijoeiro no Estado de São Paulo. Ciência e Cultura, v.40, n.12, p. 1213-1219, 1988.

PORTES, T. A. Ecofisiologia. In: ZIMMERMANN, M. O. J.; ROCHA, M.; YAMADA, T. (Ed.) Cultura do feijoeiro: fatores que afetam a produtividade. Piracicaba: Associação Brasileira de Pesquisa da Potassa e do Fosfato, 1988. p.125-156.

PYNDJI, M.; TRUTMANN, P. Managing angular leaf spot on commom bean in Africa by supplementing farmer mixtures with resistant varieties. Plant Disease, v.76, n.11, p.123, 1992.

RAWLIINSON, C. J.; MUTHYALU, G.; CAYLEY, G. R. Fungicide effects on light leaf spot, canker, crop growth and yield of winter oil-seed rape. Journal of Agricultural Science, v.103, p.613-628, 1984.

RICHARDSON, M. J.; JACKS, M;. SMITH, S. Assessment of loss caused by barley mildew using single tillers. Plant Pathology, v.24, p.21-26, 1975.

RIOS, G. P. Ferrugem. In: SARTORATO, A. ; RAVA, C.A. Principais doenças do feijoeiro comum e seu controle. Brasília: EMBRAPA, 1994. p.69-94. (EMBRAPA CNPAF. Documentos, 50).

RODRIGUES, F. D.; FERNANDES, J. J.; MARTINS, M. Influence of successive bean plantings on the severity of angular leaf spot and rust and yield losses. Pesquisa Agropecuária Brasileira, v.34, n.8, p.1373-1378, 1999.

ROERMUND, H. J. W. van; SPITTERS, C. J. T. Simulation of yield reduction by leaf rust in winter wheat, applied to analysis of genetic variation in partial resistance. Netherlands Journal of Plant Pathology, v.96, p.17-28, 1990.

ROSS, J. The radiation regime and architecture of plant stands. The Hague: Junk,1981. 137p. 
ROSSING, W. A. H.; VAN OIJEN, M.; VAN DER WERF, W.; BASTIAANS, L.; RABBINGE, R. Modeling the effects of foliar pests and pathogens on light interception, photosynthesis, growth rate and yield of field crops. In: AYRES, P. G. (Ed.) Pests and pathogens: plant responses to foliar attack. Oxford: Bios Scientific, 1992. p.161-180.

ROTEM, J.; BASHI, E.; KRANZ, J. Studies of crop loss in potato blight caused by Phytophthora infestans. Plant Pathology, v.32, p.117-122, 1983 a.

ROTEM, J.; KRANZ, J.; BASHI, E. Measurement of healthy and diseased halum area for assessing late blight epidemics in potatoes. Plant Pathology, v.32, p.109-115, $1983 b$.

ROUSE, D. I. Use of crop growth-models to predict the effects of disease. Annual Review of Phytopathology, v.26, p.183-201, 1988.

SACHE, I.; ZADOKS, C. Effect of rust (Uromyces viciae - fabae) on yield components of faba bean. Plant Pathology, v.44, p.675-685, 1994.

SAETTLER, A. W. Angular leaf Spot. In: HALL, R. (Ed.) Compendium of bean disease. St. Paul: The American Plytopatological Society, 1994. p. 15-16.

SARTORATO, A. Antracnose. In: ZIMMERMANN, M. J. O.; ROCHA, M.; YAMADA, T. Cultura do feijoeiro: fatores que afetam a produtividade. Piracicaba: Potafos, 1988. p.457-477.

SARTORATO, A.; RAVA, C. A. Influência da cultivar e do número de inoculações na severidade da mancha angular (Isariopsis griseola) e nas perdas de produção do feijoeiro comum (Phaseolus vulgaris). Fitopatologia Brasileira, v.17, p.247$251,1992$.

SARTORATO, A.; RAVA, C. A.; YOKOYAMA, M. Principais doenças e pragas do feijoeiro comum no Brasil. Goiânia: Embrapa, CNPAF, 1983. 50p. (EMBRAPA CNPAF. Documento, 5).

SCHINEIDER, R. E.; WILLIAMS, R. J.; SINCLAIR, J. B. Cercospora leaf spot of cowpea: Models for estimating yield loss. Phytopathology, v.66, p.384-388, 1976. 
SCHWARTZ, H. F. Bean rust. In: ROBERT, H. Compendium of bean disease. St. Paul: American Phytopatological Society, 1994. p. 1-4.

SCHWARTZ, H. F.; GÁlVEZ, G. E. Problemas de producción del frijol: enfermedades, insectos, limitaciones, edáficas y climáticas de Phaseolus vulgaris. Cali: CIAT, 1980. 423p.

SCHWARTZ, H. F.; PASTOR-CORRALES, M. A.; SINGH, S. P. New sources of resistance to anthracnose and angular leaf spot of beans. (Phaseolus vulgaris, L.) Euphytica, v.31, p.741-754, 1982.

SHAW, M. W.; ROYLE, D. J. Estimation and validation of a function describing the rate at which Mycospaherella graminicola causes yield loss in winter wheat. Annals of applied Biology, v.115, p.425-442, 1989.

SILVA, M. B. da. Área foliar verde para estimar danos causados por doenças do feijão comum Viçosa, 1997. 78p. Tese (Doutorado) - Universidade Federal de Viçosa.

SILVA, M. B. da; VALE, F. X. R. do; ZAMBOLIM, L.; HAU, B.; BERGAMIN FILHO, A. Relação entre severidade de doença, área foliar sadia, absorção da área foliar sadia e produção na cultura do feijão. Summa Phytopathologica, v.24, n.3 - 4, p.226-231, 1998.

SPITTERS, C. J. T.; VAN ROERMUND, H. J. W.; VAN NASSAU, H. G. M. G.; SCHEPERS, J.; MESDAG, J. Genetic variation in partial resistance to leaf rust in winter wheat: disease progress, foliage senescence and yield reduction. Netherlands Journal of Plant Pathology, v.96, p.3-15, 1990.

STAVELY, J. R. Rust. In: HALL, R. (Ed) Compendium of bean disease. St. Paul: The American Phytopatological Society, 1994. p. 1-4.

SUBBA RAO, K. V.; YANG, X. B.; BERGGREN, G. T.; SNOW, J. P A multiple regression model to estimate the contributions of leaves and the effects of leaf rust on yield of winter wheat. Phytopathology, v.79, n.11, p.1233-1238, 1989.

TANAKA, M. A.; JUNQUEIRA NETO, A. Efeito de fungicidas sobre a intensidade de doenças na parte aérea e a qualidade sanitária da semente de feijão. Fitopatologia Brasileira, v. 7, p.381-386, 1982. 
TENG, P.S. Construction of predictive models: II. Forecasting crop losses. Advances in Plant Pathology, v.3, p.179-206, 1985.

TENG, P.S. Quantifying the relationship between disease intensity and yield loss. In: TENG, P.S. (Ed.) Crop loss assesment and pest management. St. Paul: The American Phytopathological Society, 1987. p.105-113.

VALE, F. X. R.; ZAMBOLIM, L. Influência da temperatura e da umidade nas epidemias de doenças de plantas. In: LUZ, W. C.; FERNANDES, J. M. C.; PRESTES, A. M.; PICININI, E. C. (Ed.) Revisão anual de patologia de plantas. Passo Fundo: EMBRAPA, CNPT, 1996. v.4, p.14-207.

VANDERPLANK, J. E. Plant diseases: epidemics and control. New York: Academic Press, 1963. 344p.

VIEIRA, C. Principais doenças do feijoeiro no inverno. Informe Agropecuário, v.17, p.46-53, 1994.

VIEIRA, J. L. T. M. Produção e comercialização no Brasil. In; ZIMMERMANN, M.

J. de O.; ROCHA, M.; YAMADA, T. Cultura do feijoeiro: fatores que afetam a produtividade. Piracicaba: Potafos, 1988. p.21-35.

VOYSEST, O. Variedades de frijol en América Latina y su origem. Cali: CIAT, 1983. $87 \mathrm{p}$.

WAGGONER, P. E.; BERGER, R. D. Desfoliation, disease and growth. Phytopathology, v.77, p.393-398, 1987.

WATSON, D. J. Comparative physiological studies on the growth of field crops. I. Variation in net assimilation rate and leaf area between species and varieties, and within and between years. Annals of Botany, v.11, p.41-76, 1947.

WEELES, J. M.; NORMAN, J. M. Instrument for indirect measurement of canopy architecture. Agronomy Journal, v.83, p.818-825, 1991.

WILKERSON, G. G.; JONES, J. W.; POE, S. L. Effect of defoliation on peanut planta growth. Crop Science, v.24, p.526-531, 1984.

YANG, X. B.; DOWLER, W. M.; TSCHANZ, A. T.; WANG, T. C. Comparing the effects of rust on plot yield, plant yield, yield components, and vegetative parts of soybean. Journal of Phytopathology, v.136, p.46-56, 1992. 
ZADOKS, J. D. On the conceptual basis of crop loss assessment: the threshold theory. Annual Review of Phytopathology, v.23, p.455-473, 1985.

ZADOKS, J. C.; SCHEIN, R. D. Epidemiology and plant disease management. Oxyford: University Press, 1979. 427p.

ZAUMEYER, W. J.; THOMAS, H. R. A monographic study of bean disease and methods for their control. Washington: USDA, 1957. 15p. (Technical Bulletin, 868). 